\title{
DEVELOPMENT OF A VALIDATED MODEL FOR USE IN MINIMIZING NOx EMISSIONS AND MAXIMIZING CARBON UTILIZATION WHEN CO-FIRING BIOMASS WITH COAL
}

\section{Quarterly Report}

Reporting Period Start Date: $\quad$ 4/1/2001

Reporting Period End Date: 6/30/2001

\author{
Larry G. Felix, SoRI \\ P. Vann Bush, SoRI
}

July 17, 2001

DOE Cooperative Agreement No. DE-FC26-00NT40895

Southern Research Institute

2000 Ninth Avenue South

P. O. Box 55305

Birmingham, AL 35255-5305 


\section{DISCLAIMER}

"This report was prepared as an account of work sponsored by an agency of the United States Government. Neither the United States Government nor any agency thereof, nor any of their employees, makes any warranty, express or implied, or assumes any legal liability or responsibility for the accuracy, completeness, or usefulness of any information, apparatus, product, or process disclosed, or represents that its use would not infringe privately owned rights. Reference herein to any specific commercial product, process, or service by trade name, trademark, manufacturer, or otherwise does not necessarily constitute or imply its endorsement, recommendation, or favoring by the United States Government or any agency thereof. The views and opinions of authors expressed herein do not necessarily state or reflect those of the United States Government or any agency thereof." 


\section{ABSTRACT}

This is the third Quarterly Technical Report for DOE Cooperative Agreement No. DE-FC26-00NT40895. A statement of the project objectives is included in the Introduction of this report. Three additional biomass co-firing test burns have been conducted. In the first test (Test 3), up to $20 \%$ by weight dry hardwood sawdust and dry switchgrass was injected through the center of the burner. In the second test (Test 4), 100\% Pratt seam coal was burned in a repeat of the initial test condition of Test 1, to reconcile irregularities in the data from the first test. In the third test (Test 5), up to $20 \%$ by weight dry hardwood sawdust and dry switchgrass was injected through an external pipe directed toward the exit of the burner. Progress has continued in developing a modeling approach to synthesize the reaction time and temperature distributions that will be produced by computational fluid dynamic models of the pilot-scale combustion furnace and the char burnout and chemical reaction kinetics that will predict NOx emissions and unburned carbon levels in the furnace exhaust. Additional results of CFD modeling efforts have been received and Preparations are under way for continued pilot-scale combustion experiments. Finally, a presentation was made at a Biomass Cofiring Project Review Meeting held at the NETL in Pittsburgh, PA on June 20-21. 


\section{TABLE OF CONTENTS}

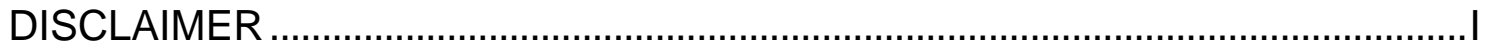

ABSTRACT .................................................................................................

TABLE OF CONTENTS …...................................................................................ii

LIST OF TABLES ..................................................................................................

LIST OF FIGURES.........................................................................................

INTRODUCTION

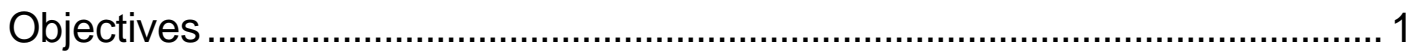

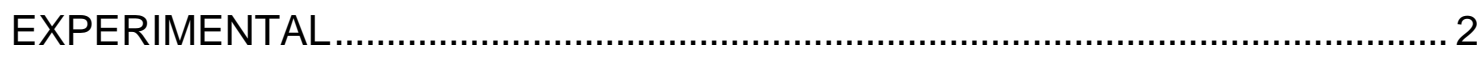

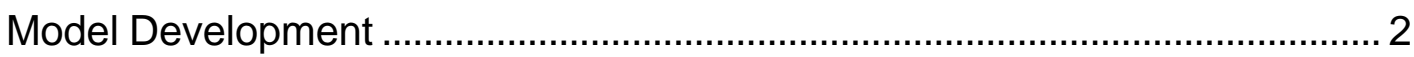

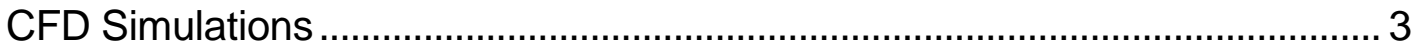

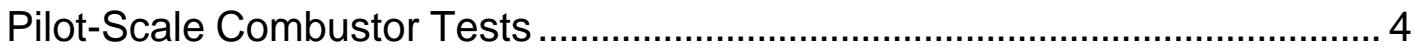

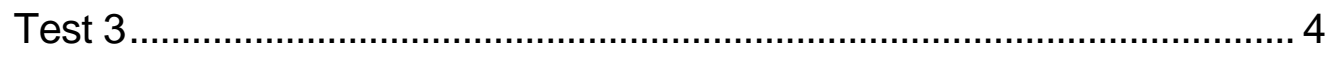

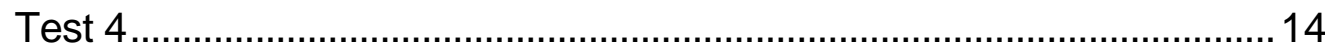

Test 5

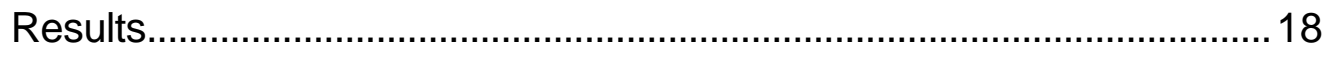

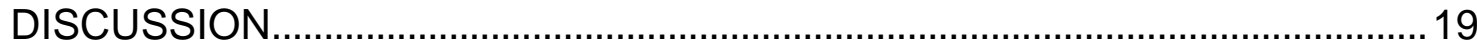

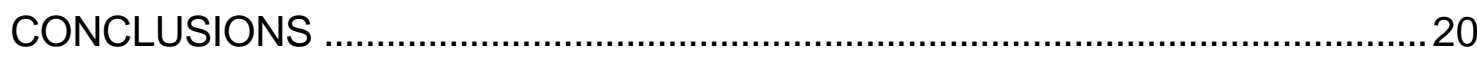

APPENDIX A - Recommended Parameter Values for Fuel Decomposition

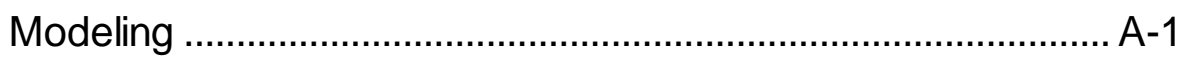

APPENDIX B - Reports of CFD simulations completed by REI, Inc ................ B-1

APPENDIX C - NETL Project Review Presentation........................................... C-1 


\section{LIST OF TABLES}

1. NOx Emissions for Various Levels of Overfire Air at 3.5\% Furnace Exit $\mathrm{O}_{2}$, (wet) for Sawdust and for Switchgrass Co-milled with Pratt Seam Coal Injected through the Center of the Single Register Burner.......................... 12

2. NOx Emissions for Various Levels of Overfire Air at 3.5\% Furnace Exit $\mathrm{O}_{2}$, (wet) for Sawdust and for Switchgrass Injected through the Center of the Single Register Burner (Test 3 with Pratt seam coal).

\section{LIST OF FIGURES}

1. Locations for biomass injection in the SoRI/SCS furnace equipped with a single-register burner. 5

2. Comparison of comilled (baseline) firing mode versus the burner configured for axial (center) biomass injection. Single register burner....... 7

3. Comilled (baseline) firing mode for sawdust and switchgrass with no overfire air. Single register burner.

4. Comilled (baseline) firing mode for sawdust and switchgrass with $15 \%$ overfire air. Single register burner.

5. Center injection (axial) firing mode for sawdust and switchgrass with no overfire air. Single register burner.

6. Center injection (axial) firing mode for sawdust and switchgrass with $15 \%$ overfire air. Single register burner.

7. NOx reductions resulting from dry hardwood sawdust and switchgrass comilled with Pratt Seam coal as a function of furnace exit oxygen for $0 \%$ and $15 \%$ overfire air.

8. NOx reductions resulting from dry hardwood sawdust and switchgrass added through the center of the single-register burner as a function of furnace exit oxygen for $0 \%$ and $15 \%$ overfire air. All results for Pratt seam coal.

9. $100 \%$ Pratt seam coal, baseline (comilling) burner configuration. NOx emissions as a function of furnace exit oxygen for $0 \%, 15 \%$, and $30 \%$ overfire air. 


\section{INTRODUCTION}

The work to be conducted in this project received funding from the Department of Energy under Cooperative Agreement No. DE-FC26-00NT40895. This project has a period of performance that commenced September 20, 2000 and continues through September 19, 2002. A project Work Plan was submitted to DOE on October 18, 2000 as the first deliverable under the cooperative agreement. The Work Plan is not included in this report, but the objectives of the project are restated from the Work Plan in the following paragraphs.

\section{Objectives}

The project is designed to balance the development of a systematic and expansive database detailing the effects of co-firing parameters on nitrogen oxides (NOx) formation with the complementary modeling effort that will yield a capability to predict, and therefore optimize, NOx reductions by the selection of those parameters.

The database of biomass co-firing results will be developed through an extensive set of pilot-scale tests at the Southern Company/Southern Research Institute Combustion Research Facility. The testing in this program will monitor NOx, LOI, and other emissions over a broad domain of biomass composition, coal quality, and co-firing injection configurations to quantify the dependence of $\mathrm{NOx}$ formation and LOI on these parameters. This database of co-firing cases will characterize an extensive suite of emissions and combustion properties for each of the combinations of fuel and injection configuration tested.

The complementary process modeling will expand the value of the raw test data by identifying the determining factors on NOx emissions and LOI. Niksa Energy Associates will develop and validate a detailed process model for predicting NOx emissions and LOI from biomass co-firing that builds on a foundation of existing and proven fluid dynamics, reaction kinetics, and combustion products models. The modeling will resolve all major independent influences, including biomass composition, coal quality, chemical interactions among biomass-and coal-derived intermediate species, competitive $\mathrm{O}_{2}$ consumption by biomass- and coal-derived intermediate species and chars, extent of biomass/coal mixing prior to combustion, and mixing intensity during biomass injection.

The overall goal of the project is to produce a validated tool or methodology to accurately and confidently design and optimize biomass co-firing systems for full- 
scale utility boilers to produce the lowest $\mathrm{NO}_{\mathrm{x}}$ emissions and the least unburned carbon. Specific program objectives are:

- Develop an extensive data set under controlled test conditions that quantifies the relationships between $\mathrm{NO}_{x}$ emissions and biomass co-firing parameters.

- Provide a data set of the effects of biomass co-firing over a broad range of fuels and co-firing conditions on flame stability, carbon burnout, slagging and fouling, and particulate and gaseous emissions.

- Develop and validate a broadly applicable computer model that can be used to optimize NOx reductions and minimize unburned carbon from biomass cofiring.

Once validated, the model provides a relatively inexpensive means to either (1) identify the most effective co-firing injection configuration for specified compositions of biomass and coal within a particular furnace environment, or (2) to forecast the emissions for a specified pair of fuels fired under an existing configuration. As such an important cost-saving tool, the modeling has the potential to accelerate widespread adoption of biomass co-firing as a $\mathrm{NO}_{x}$ control strategy in the electric utility industry.

\section{EXPERIMENTAL}

\section{Model Development}

The three independent aspects of modeling for this project are (1) the mechanisms for fuel devolatilization and char burnout, and (2) the detailed chemical mechanism for combustion and fuel-N conversion in the gas phase, and (3) the equivalent reactor network. To this point in the project, Niksa Energy Associates (NEA) has focused on the first two aspects, and are now beginning to work on the third.

As submodels for fuel decomposition, NEA is using bio-FLASHCHAIN (bio-FC) and Prof. Robert Hurt's CBK model. Their only sample-specific input requirements are the proximate (PA) and ultimate (UA) analyses. Both models are fully operational, and both have been incorporated into a comprehensive fuel decomposition submodel called PC Coal Lab ${ }^{\circledR}$, the form in which they will be implemented in the chemistry simulations. Also, the fuel decomposition submodels were recently used to specify all rate parameters for devolatilization 
and char burnout in REl's CFD simulations. In this way, the simple global reaction mechanisms in the CFD simulations are being related to the detailed mechanisms in the chemistry simulations.

Both of these chemical submodels have been incorporated into a computer program that sequences the calculations through a network of idealized reactor elements.

Chemistry across the reactor network will be simulated by combining two commercial software packages with a sequencing routine that moves through all the elements in the network. The fuel decomposition and burnout chemistry will be based on NEA's PC Coal Lab ${ }^{\circledR}$ software. PC Coal Lab ${ }^{\circledR}$ uses FLASHCHAIN ${ }^{\circledR}$ to model the devolatilization of biomass and coal, and Prof. Bob Hurt's CBK model for the char oxidation stage. The kinetics for chemistry in the gas phase, including fuel-N conversion, will be simulated with Reaction Design's CHEMKIN III software. The main sequencing routine lays out the sequence of calculations for all the elements in the network. For each element, the calculations determine how much oxygen is consumed by fuel decomposition and burnout (from PC Coal Lab) and by combustion in the gas phase (from CHEMKIN III). The program will iterate until convergence for each element, then move along to the next element until the entire network has been simulated. In a previous application with this approach, the NOX and LOI emissions throughout a fullscale $550 \mathrm{MW}$ furnace could be computed in about 30 min on a desktop PC. Furthermore, the incorporation of such commercial packages significantly reduces the development time for the custom-build sequencing routine.

In the near term, NEA is concentrating on specifying the reactor network from the CFD flowfield. The first application of the program will establish the performance with coal-only, baseline cases. Once these cases have been validated, NEA will move on to biomass co-firing cases that have already been run in the testing program. A copy of NEA's report to REI entitled "Recommended Parameter Values for Fuel Decomposition Modeling" is included here as Appendix A.

\section{CFD Simulations}

Reaction Engineering International, Inc. (REI) has completed a further simulation of the single register burner used in the pilot-scale combustor, this with Pratt Seam coal comilled with $20 \%$ hardwood sawdust. A copy of the REA report is included as Appendix $B$ of this report. One result from this simulation that is 
readily apparent is that temperatures low in the furnace are lower than with $100 \%$ Pratt Seam coal.

\section{Pilot-Scale Combustor Tests}

Three additional combustor tests have been performed. In the first test (Test 3), up to $20 \%$ by weight pulverized, dry hardwood sawdust and dry switchgrass was injected through the center of the burner (location 2 in Figure 1). In the second test (Test 4), 100\% Pratt seam coal (nominal 1.6\% S) was burned in a repeat of the initial, coal-only, test condition of Test 1 , to reconcile irregularities in the data from the first test. In the third test (Test 5), up to $20 \%$ by weight pulverized, dry hardwood sawdust and dry switchgrass was injected through an external pipe directed toward the exit of the burner (location 3 in Figure 1).

All biomass (sawdust and switchgrass) were processed by MESA Reduction Engineering and Processing, Inc in a collision mill of their design. When fitted to a Rosin-Rammler (Weibull) distribution, the $D_{50}$ of pulverized coal (nominally $70 \%$ less than 200 mesh) is 50 micrometers, the $D_{50}$ of MESA-processed sawdust is approximately 300 micrometers and the $D_{50}$ of MESA-processed switchgrass is approximately 600 micrometers. We are currently working with MESA to obtain switchgrass processed to the same fineness as the dry hardwood sawdust.

Biomass is injected according to the scheme developed during Test 2 (as reported in the second Quarterly Progress Narrative). In this arrangement, finely divided biomass is delivered through a screw feeder into an eductor fed by compressed air that aspirates biomass into an air stream that passes through a grounded 1 in. diameter plastic tube to a thin-wall stainless steel tube into the furnace. The biomass screw feeder and the plastic tube conveying the biomassair mixture to the furnace is grounded to prevent electrical charge from building up. With this equipment, weight percent additions of biomass up to $20 \%$ have been maintained for extended periods.

Test 3 For the third test, from April 8-14, 2001, the single register burner was kept in the axial injection configuration used for Test 2 . That is, the burner pipe was modified so that finely divided hardwood sawdust and switchgrass (prepared by MESA Reduction Engineering) could be injected through the center of the 3.5 inch (outer diameter, 0.125 inch wall thickness) burner. This modification was effected by enlarging the existing blast pilot tube to 1.5 inches outside diameter from the original 1-inch pipe ( 1.3 inch outside diameter) and inserting a 1 inch 


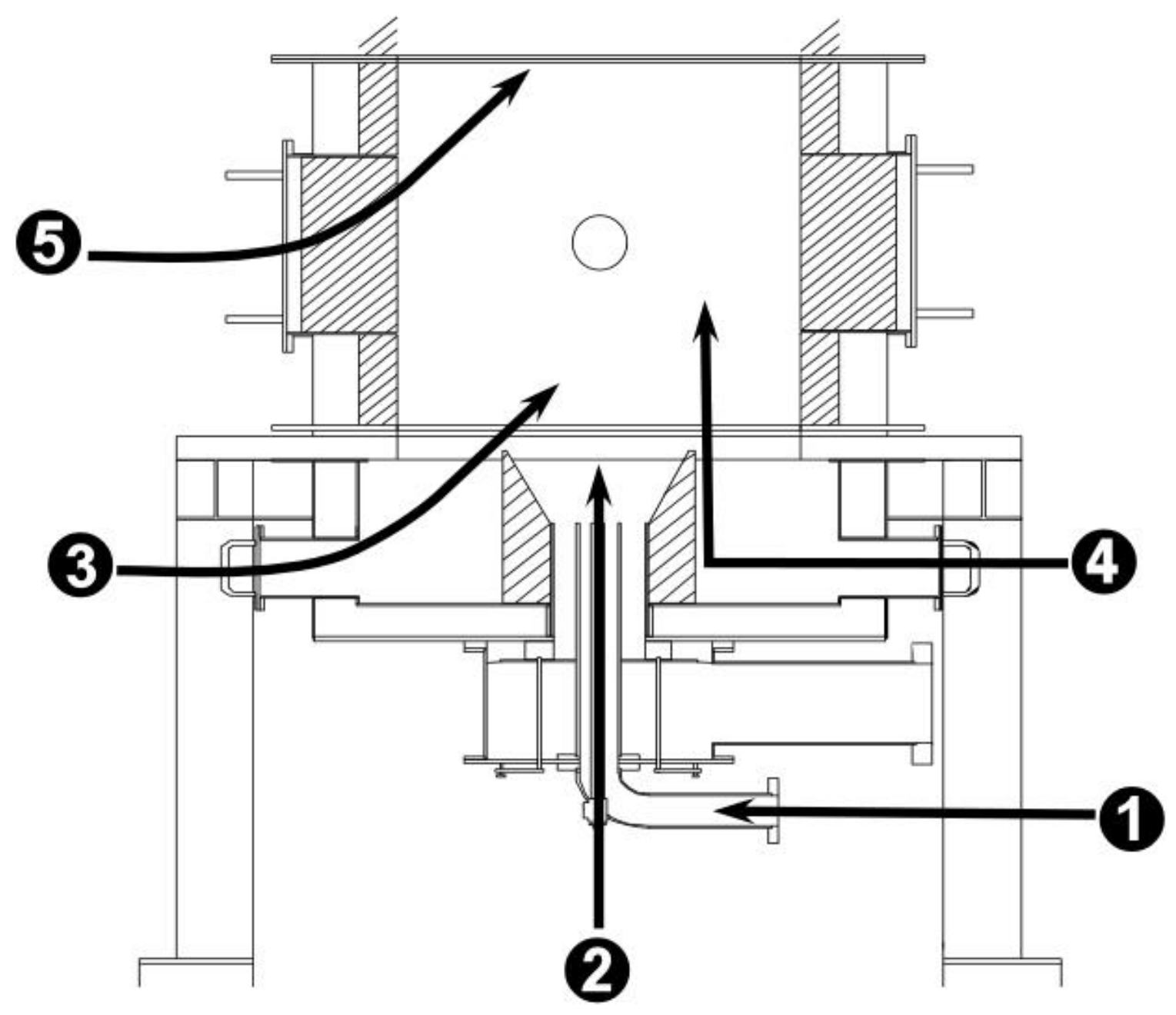

Figure 1. Locations for biomass injection in the SoRI/SCS furnace equipped with a single-register burner. 
outside diameter tube through the center of the enlarged blast pilot. Biomass is injected through thiscenter tube and natural gas for ignition is directed through the 0.125 inch annular space between the inner and outer tubes. Thus, the blast pilot assembly can function either as a natural gas igniter or as a location for biomass injection.

Testing was uneventful and all mixtures combusted well, without slagging or fouling beyond what has been observed with raw Pratt Seam coal. However, because this coal has a high ash content ( 14\%), the amount of furnace bottom ash that is generated with this coal is greater than average. Three levels of furnace exit oxygen were tested $(2.5 \%, 3.5 \%$, and $4.5 \%)$ along with overfire air levels of $0 \%$ and $15 \%$.

Because a high air velocity ( 90-100 ft/sec) is required to convey up to $60 \mathrm{lb}$ of biomass per hour with a sufficient safety factor to prevent flashback through the axial biomass injection system, a considerable quantity of cold (room temperature) air is injected into the center of the coal flame. In this configuration, when no biomass is injected, the thermal environment at the root of the coal flame experiences even more cooling by this jet of air and, as might be expected, NOx emissions change compared to the nominal comilling configuration (location 1 in Figure 1). Figure 2 demonstrates this observation, showing that without overfire air, the effect of adding air to the root of the flame is to raise and flatten the NOx versus furnace exit oxygen (FEO) curve. In this configuration, below FEO levels of about $4 \%$, NOx emissions are greater than those measured for the baseline (comilling) case. When overfire air is added, the shape of the NOx versus FEO curve is maintained, but with axial injection of air (without biomass), NOx emissions are always greater than those measured for the baseline (comilling) case.

Figures 3 and 4 present average NOx emissions measured for biomass comilled with Pratt Seam coal and Figures 5 and 6 present average NOx emissions recorded for biomass injected through the center of the burner (axial injection). Tables 1 summarizes the data presented in Figures 3 and 4 and Table 2 summarizes the data presented in Figures 5 and 6 . These tables also show the reductions in NOx emissions that can be expected by the addition of biomass. Overall, for both comilling and axial injection of biomass, the effect of adding biomass is to reduce NOx emissions. However, as Figure 6 and Table 2 shows, with the center-axial injection of biomass at an overfire air level of $15 \%$, NOx emissions can exceed those of $100 \%$ coal for furnace exit oxygen levels greater than about $4 \%$. 


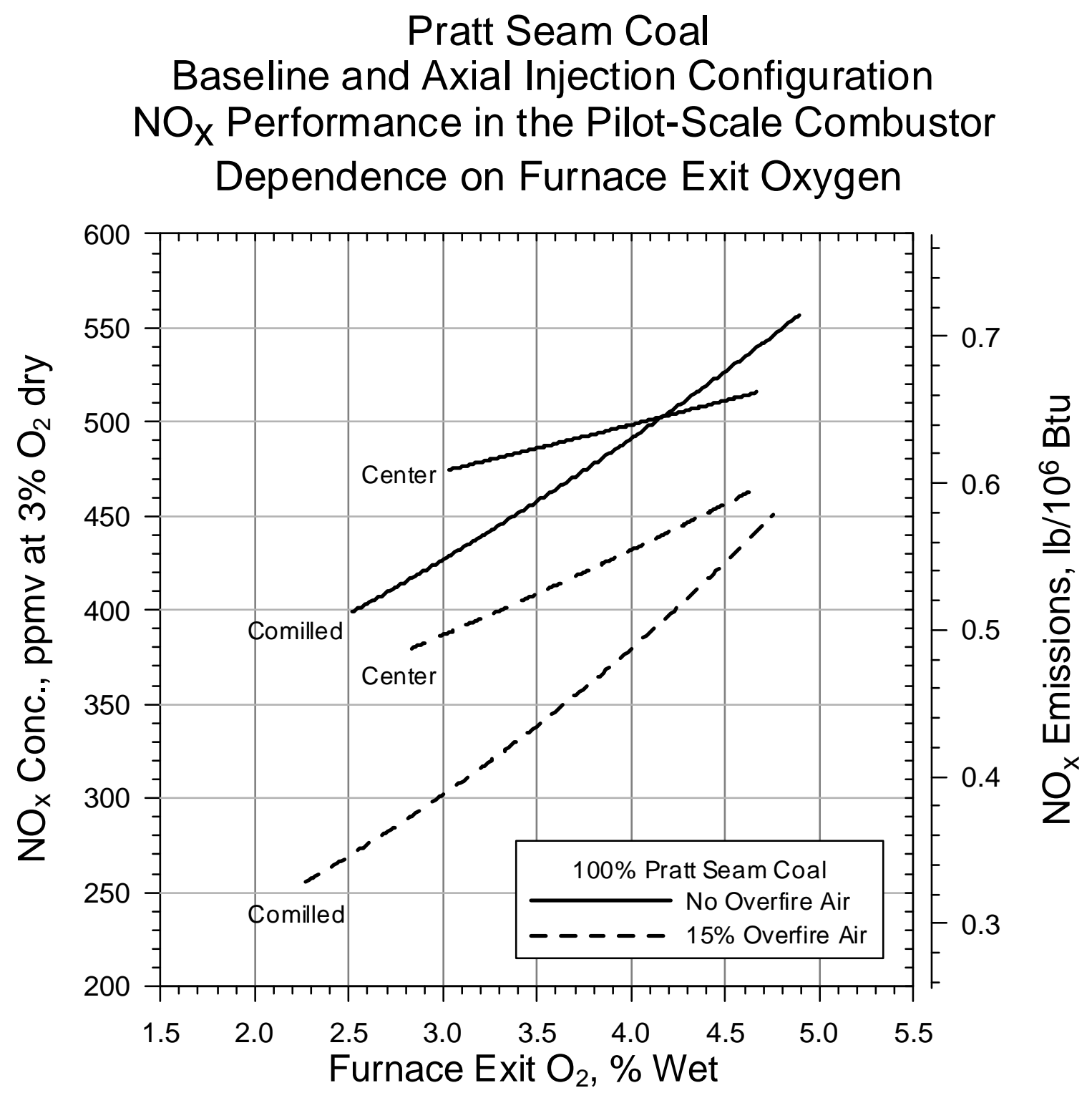

Figure 2. Comparison of comilled (baseline) firing mode versus the burner configured for axial (center) biomass injection. Single register burner. 


\section{Pratt Seam Coal Comilled with Biomass $\mathrm{NO}_{\mathrm{X}}$ Performance in the Pilot-Scale Combustor Dependence on Furnace Exit Oxygen}

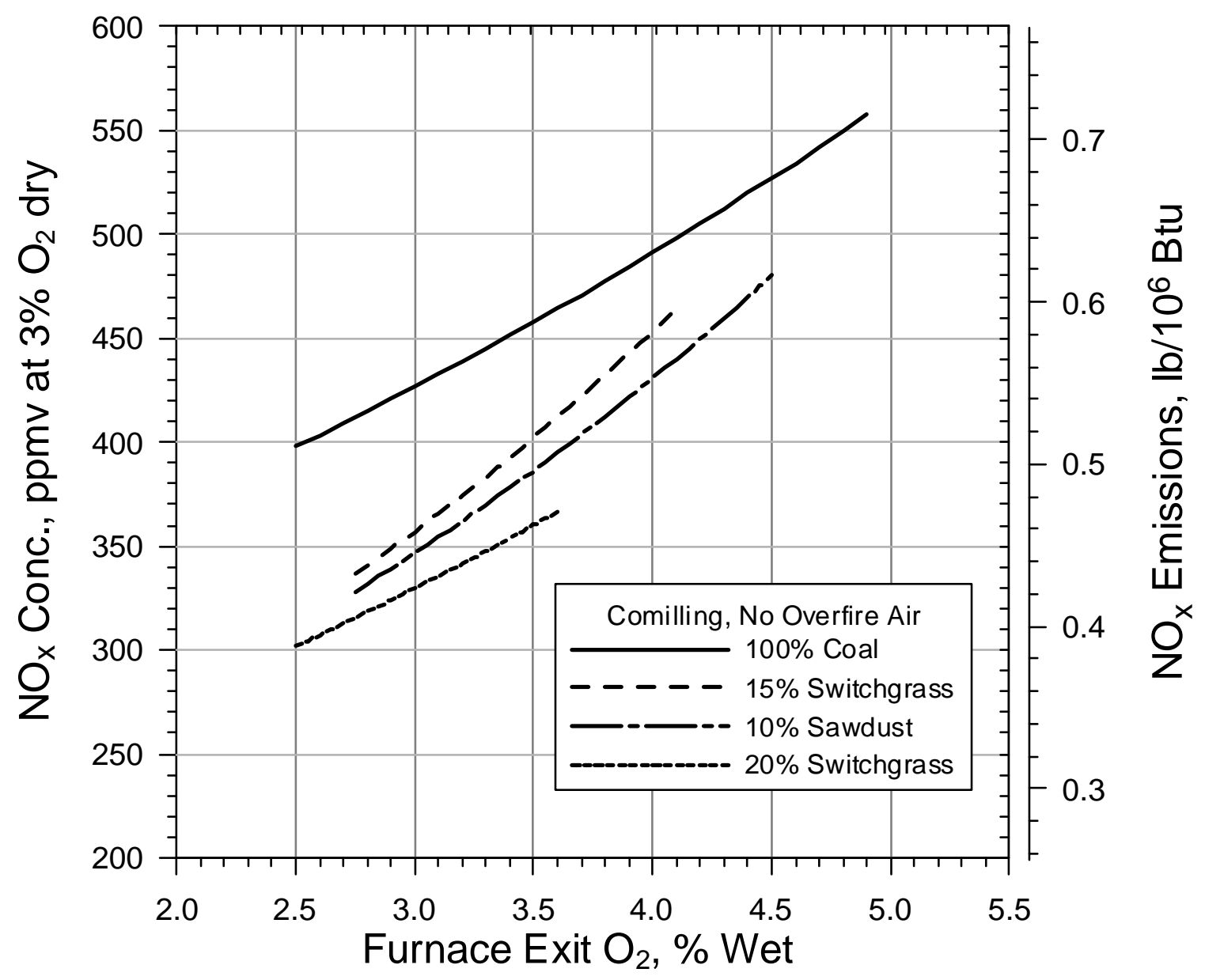

Figure 3. Comilled (baseline) firing mode for sawdust and switchgrass with no overfire air. Single register burner. 


\section{Pratt Seam Coal Comilled with Biomass $\mathrm{NO}_{\mathrm{X}}$ Performance in the Pilot-Scale Combustor Dependence on Furnace Exit Oxygen}

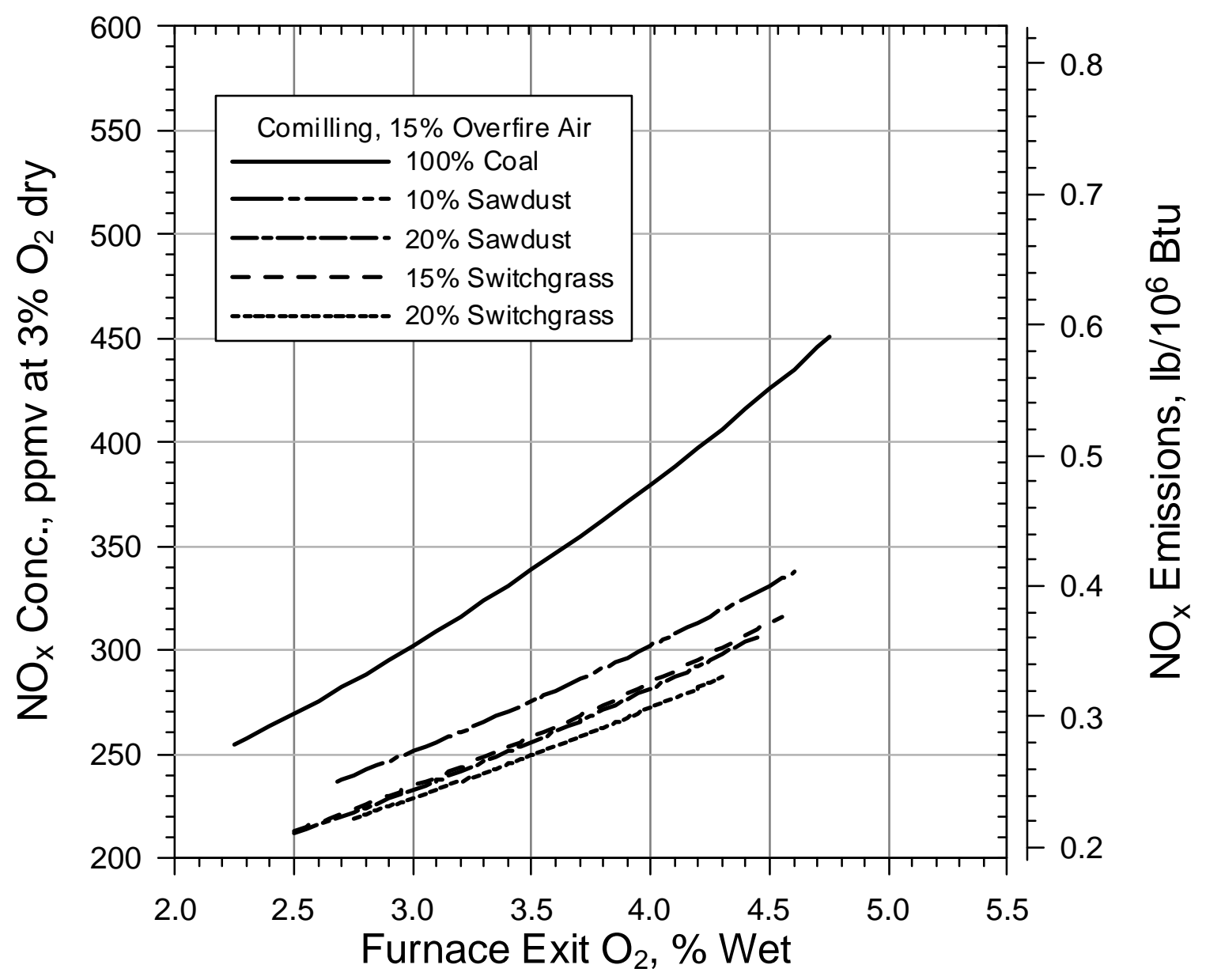

Figure 4. Comilled (baseline) firing mode for sawdust and switchgrass with $15 \%$ overfire air. Single register burner. 


\section{Pratt Seam Coal \\ Center Axial Biomass Injection \\ $\mathrm{NO}_{x}$ Performance in the Pilot-Scale Combustor Dependence on Furnace Exit Oxygen}

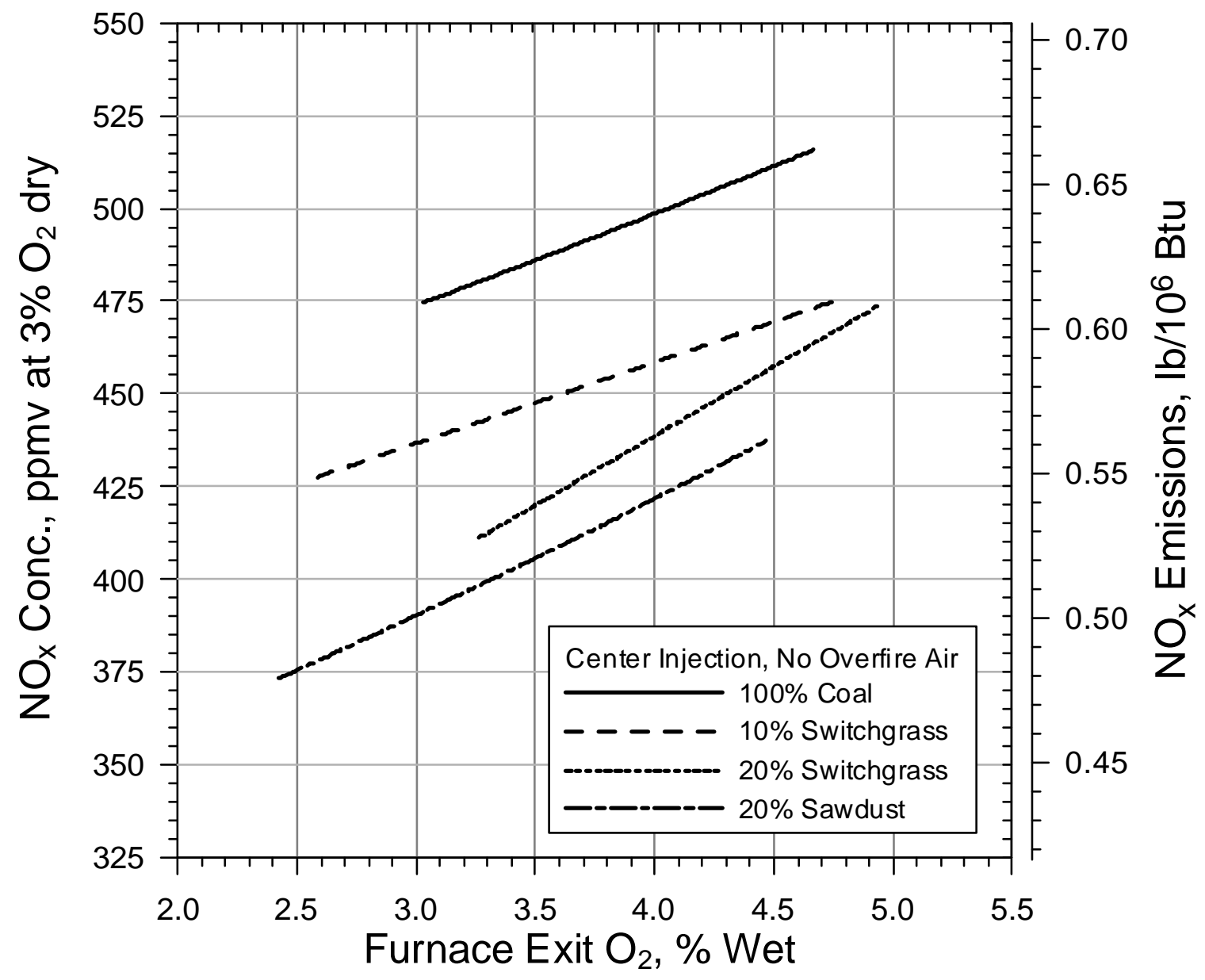

Figure 5. Center injection (axial) firing mode for sawdust and switchgrass with no overfire air. Single register burner. 


\section{Pratt Seam Coal \\ Center Axial Biomass Injection \\ $\mathrm{NO}_{x}$ Performance in the Pilot-Scale Combustor Dependence on Furnace Exit Oxygen}

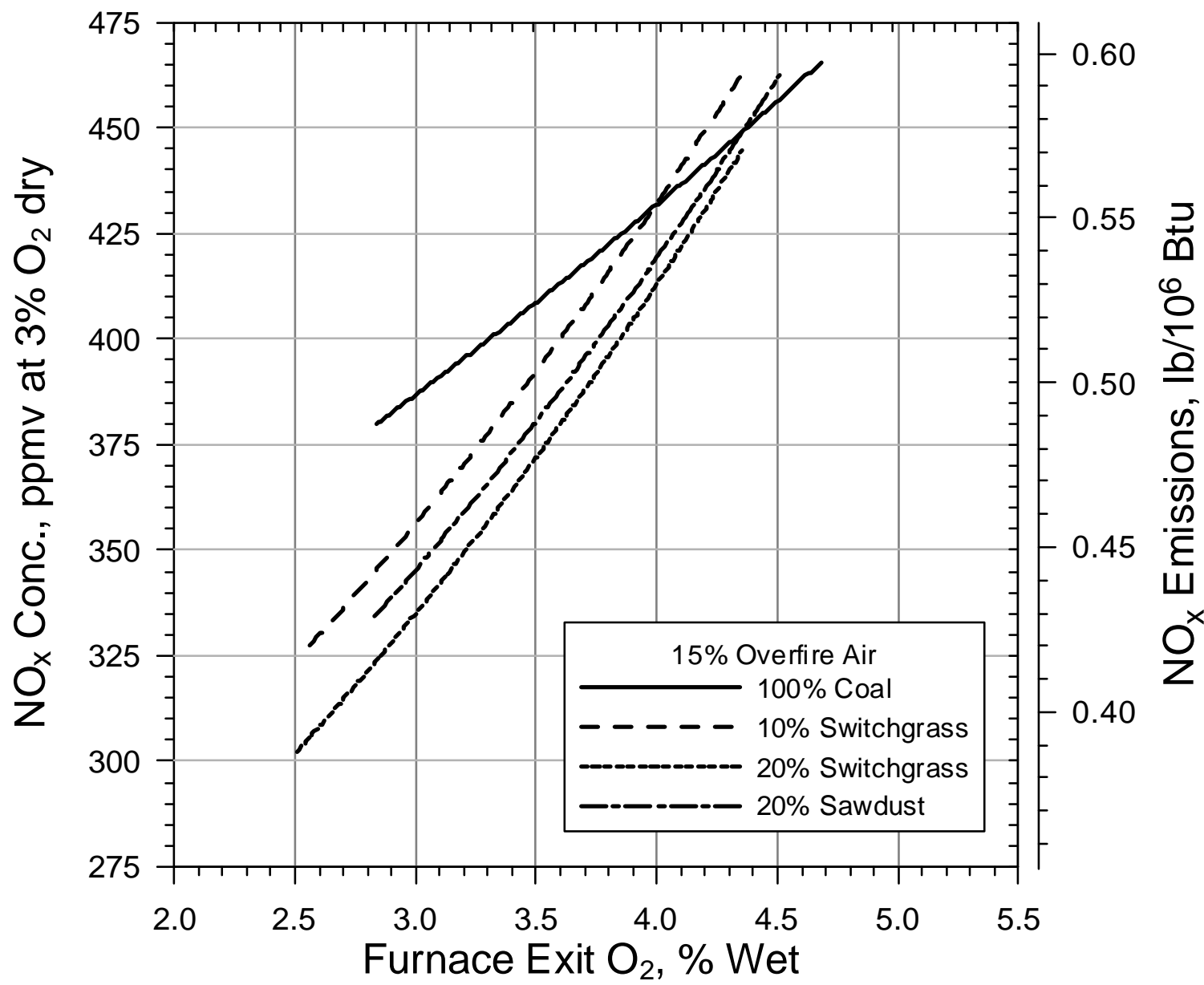

Figure 6. Center injection (axial) firing mode for sawdust and switchgrass with $15 \%$ overfire air. Single register burner. 
Table 1. NOx Emissions for Various Levels of Overfire Air at 3.5\% Furnace Exit $\mathrm{O}_{2}$, (wet) for Sawdust and for Switchgrass Co-milled with Pratt Seam Coal Injected through the Center of the Single Register Burner.

\begin{tabular}{|c|c|c|c|c|}
\hline Biomass & Weight\% & Overfire Air, \% & $\begin{array}{l}\text { NOx Emissions at } \\
3 \% \mathrm{O}_{2} \text {, dry ppmv }\end{array}$ & $\begin{array}{l}\text { Reduction of NOx } \\
\text { Emissions, \% }\end{array}$ \\
\hline \multicolumn{5}{|c|}{ 2.5\% Furnace Exit Oxygen } \\
\hline \multirow[t]{2}{*}{ None } & 0 & 0 & 398 & 0 \\
\hline & & 15 & 269 & 0 \\
\hline \multirow[t]{4}{*}{ Sawdust } & 10 & 0 & 311 & 21.9 \\
\hline & & 15 & 229 & 14.9 \\
\hline & 20 & 0 & 345 & 13.3 \\
\hline & & 15 & 212 & 21.2 \\
\hline \multirow{4}{*}{ Switchgrass } & 15 & 0 & 317 & 20.4 \\
\hline & & 15 & 213 & 20.8 \\
\hline & 20 & 0 & 302 & 24.1 \\
\hline & & 15 & 210 & 21.9 \\
\hline \multicolumn{5}{|c|}{ 3.5\% Furnace Exit Oxygen } \\
\hline \multirow[t]{2}{*}{ None } & 0 & 0 & 458 & 0 \\
\hline & & 15 & 338 & 0 \\
\hline \multirow[t]{4}{*}{ Sawdust } & 10 & 0 & 386 & 15.7 \\
\hline & & 15 & 276 & 18.3 \\
\hline & 20 & 0 & 424 & 7.4 \\
\hline & & 15 & 256 & 24.3 \\
\hline \multirow[t]{4}{*}{ Switchgrass } & 15 & 0 & 402 & 12.2 \\
\hline & & 15 & 258 & 23.7 \\
\hline & 20 & 0 & 360 & 21.4 \\
\hline & & 15 & 250 & 26.0 \\
\hline \multicolumn{5}{|c|}{ 4.5\% Furnace Exit Oxygen } \\
\hline \multirow[t]{2}{*}{ None } & 0 & 0 & 527 & 0 \\
\hline & & 15 & 426 & 0 \\
\hline \multirow[t]{4}{*}{ Sawdust } & 10 & 0 & 480 & 8.9 \\
\hline & & 15 & 331 & 22.3 \\
\hline & 20 & 0 & 523 & 0.8 \\
\hline & & 15 & 311 & 27.0 \\
\hline \multirow[t]{4}{*}{ Switchgrass } & 15 & 0 & 511 & 3.0 \\
\hline & & 15 & 313 & 26.5 \\
\hline & 20 & 0 & 430 & 18.4 \\
\hline & & 15 & 297 & 30.3 \\
\hline
\end{tabular}


Table 2. NOx Emissions for Various Levels of Overfire Air at 3.5\% Furnace Exit $\mathrm{O}_{2}$, (wet) for Sawdust and for Switchgrass Injected through the Center of the Single Register Burner (Test 3 with Pratt seam coal).

\begin{tabular}{|c|c|c|c|c|}
\hline Biomass & Weight\% & Overfire Air, \% & $\begin{array}{l}\text { NOx Emissions at } \\
3 \% \mathrm{O}_{2} \text {, dry ppmv }\end{array}$ & $\begin{array}{l}\text { Reduction of NOx } \\
\text { Emissions, \% }\end{array}$ \\
\hline \multicolumn{5}{|c|}{ 2.5\% Furnace Exit Oxygen } \\
\hline \multirow[t]{2}{*}{ None } & 0 & 0 & 462 & 0 \\
\hline & & 15 & 366 & 0 \\
\hline \multirow{4}{*}{ Sawdust } & 10 & 0 & 370 & 19.9 \\
\hline & & 15 & 295 & 19.4 \\
\hline & 20 & 0 & 375 & 18.8 \\
\hline & & 15 & 313 & 14.5 \\
\hline \multirow[t]{4}{*}{ Switchgrass } & 10 & 0 & 426 & 7.8 \\
\hline & & 15 & 323 & 11.8 \\
\hline & 20 & 0 & 383 & 17.1 \\
\hline & & 15 & 302 & 17.5 \\
\hline \multicolumn{5}{|c|}{ 3.5\% Furnace Exit Oxygen } \\
\hline \multirow[t]{2}{*}{ None } & 0 & 0 & 486 & 0 \\
\hline & & 15 & 409 & 0 \\
\hline \multirow[t]{4}{*}{ Sawdust } & 10 & 0 & 411 & 15.4 \\
\hline & & 15 & 370 & 9.5 \\
\hline & 20 & 0 & 406 & 16.5 \\
\hline & & 15 & 380 & 7.1 \\
\hline \multirow[t]{4}{*}{ Switchgrass } & 10 & 0 & 447 & 8.0 \\
\hline & & 15 & 392 & 4.2 \\
\hline & 20 & 0 & 420 & 13.6 \\
\hline & & 15 & 372 & 9.1 \\
\hline \multicolumn{5}{|c|}{ 4.5\% Furnace Exit Oxygen } \\
\hline \multirow[t]{2}{*}{ None } & 0 & 0 & 511 & 0 \\
\hline & & 15 & 456 & 0 \\
\hline \multirow[t]{4}{*}{ Sawdust } & 10 & 0 & NA & -- \\
\hline & & 15 & 463 & -1.5 \\
\hline & 20 & 0 & 438 & 14.3 \\
\hline & & 15 & 462 & -1.3 \\
\hline \multirow[t]{4}{*}{ Switchgrass } & 10 & 0 & 469 & 8.2 \\
\hline & & 15 & 476 & -4.4 \\
\hline & 20 & 0 & 457 & 10.6 \\
\hline & & 15 & 459 & -0.7 \\
\hline
\end{tabular}


Figures 7 and 8 show NOx reduction (compared to 100\% Pratt seam coal) plotted as a function of overfire air for biomass (sawdust and switchgrass) comilled with coal and for the same biomass injected through the center of the single-register burner. Some general observations can be made from Figures 7 and 8:

- NOx reductions are maximized when biomass is comilled with coal.

- For comilling with no overfire air, NOx reductions decrease with increasing furnace exit oxygen.

- For comilling with $15 \%$ overfire air, NOx reductions increase with increasing furnace exit oxygen.

- For biomass injected through the center of the burner, in all but one case, NOx reductions decreased with increasing furnace exit oxygen.

- For biomass injected through the center of the burner, the addition of overfire air tended to lower NOx production, compared to no overfire air.

Test 4 In the second test performed during this quarter, Test 4, 100\% Pratt seam coal was burned in a repeat of the initial test condition of Test 1 , to reconcile irregularities in the data from the first test. During the first day of test 1 , abnormally low NOx emissions data were recorded while 100\% Pratt seam coal was burned. In Test 4, the first day of the first test was repeated and gas emissions data were recorded. The data from this test were found to agree well with other Pratt Seam coal-only data. The results of this test are shown in Figure 9, where averages over individual test periods are shown with standard deviations indicated. Some 100\% coal conditions in Test 2 also agreed well with these data and they are shown in Figure 9 with open symbols. Curves fit to the data shown in Figure 9 were used for the 100\% Pratt seam coal results shown in Figures 3 and 4.

Test 5 For this test, from June 10-15, 2001, biomass was injected into the furnace using the third injection scheme shown in Figure 1. For this test, the injection apparatus used in Test 3 was used. However, instead of discharging into the center of the burner (as in Tests 2 and 3), the nominal 1 in. inner diameter conveying line was connected to another nominal 1 in. inside diameter stainless steel line. This conveying line passed through a lower furnace door, as shown in Figure 1 , and curved upward at a $45^{\circ}$ angle, to a straight section that terminated approximately $1.5 \mathrm{in}$. above and away from the edge of the quarl. Thus, the trajectory of exhausted biomass would intersect the edge of the coal flame approximately $1.5 \mathrm{in}$. above the top edge of the quarl. 


\section{Baseline Comilled Biomass Injection Configuration $\mathrm{NO}_{x}$ Reduction from Biomass Addition Dependence on Furnace Exit Oxygen}

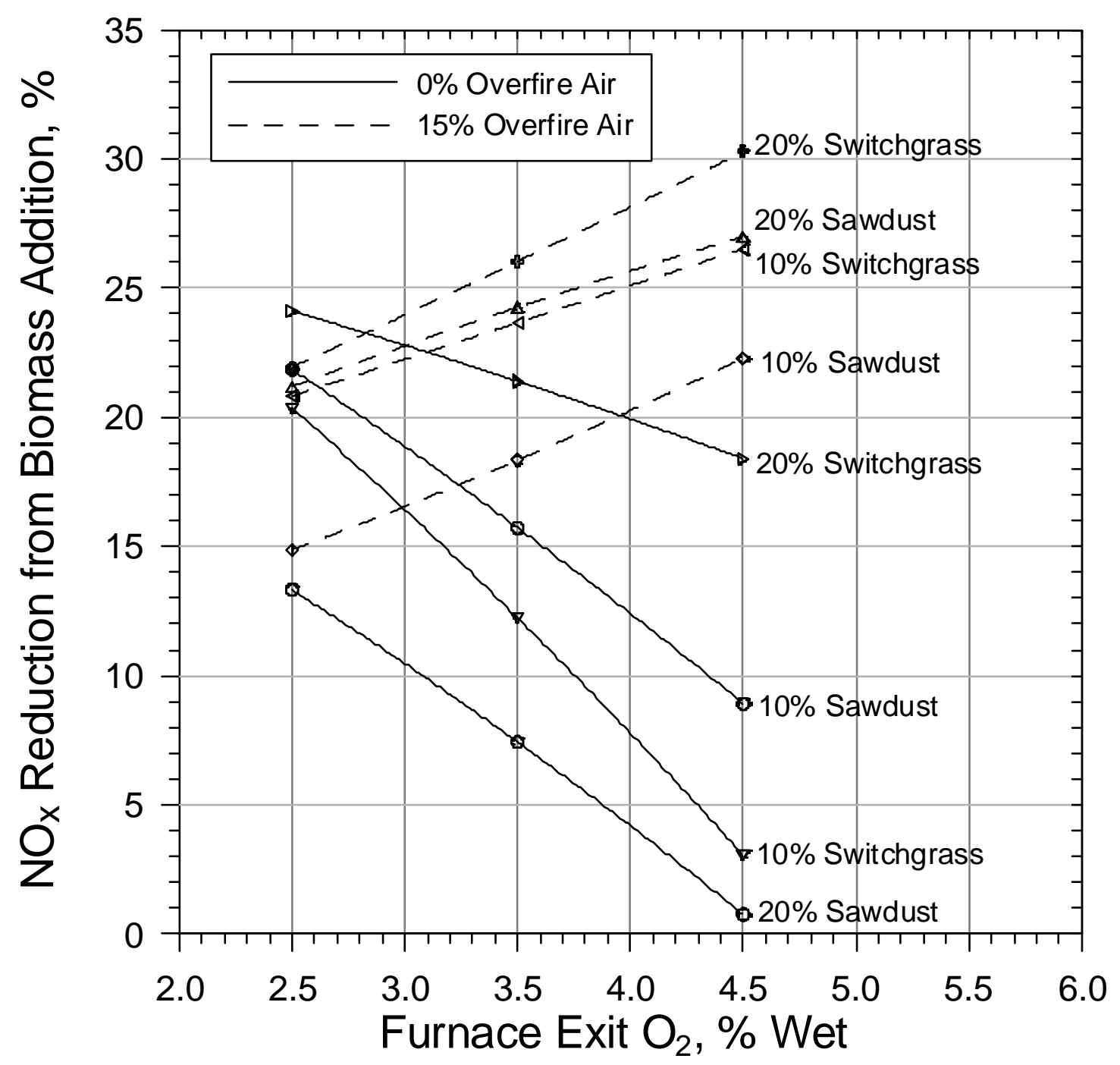

Figure 7. NOx reductions resulting from dry hardwood sawdust and switchgrass comilled with Pratt Seam coal as a function of furnace exit oxygen for $0 \%$ and $15 \%$ overfire air. 


\section{Center-Axial Biomass Injection Configuration $\mathrm{NO}_{x}$ Reduction from Biomass Addition Dependence on Furnace Exit Oxygen}

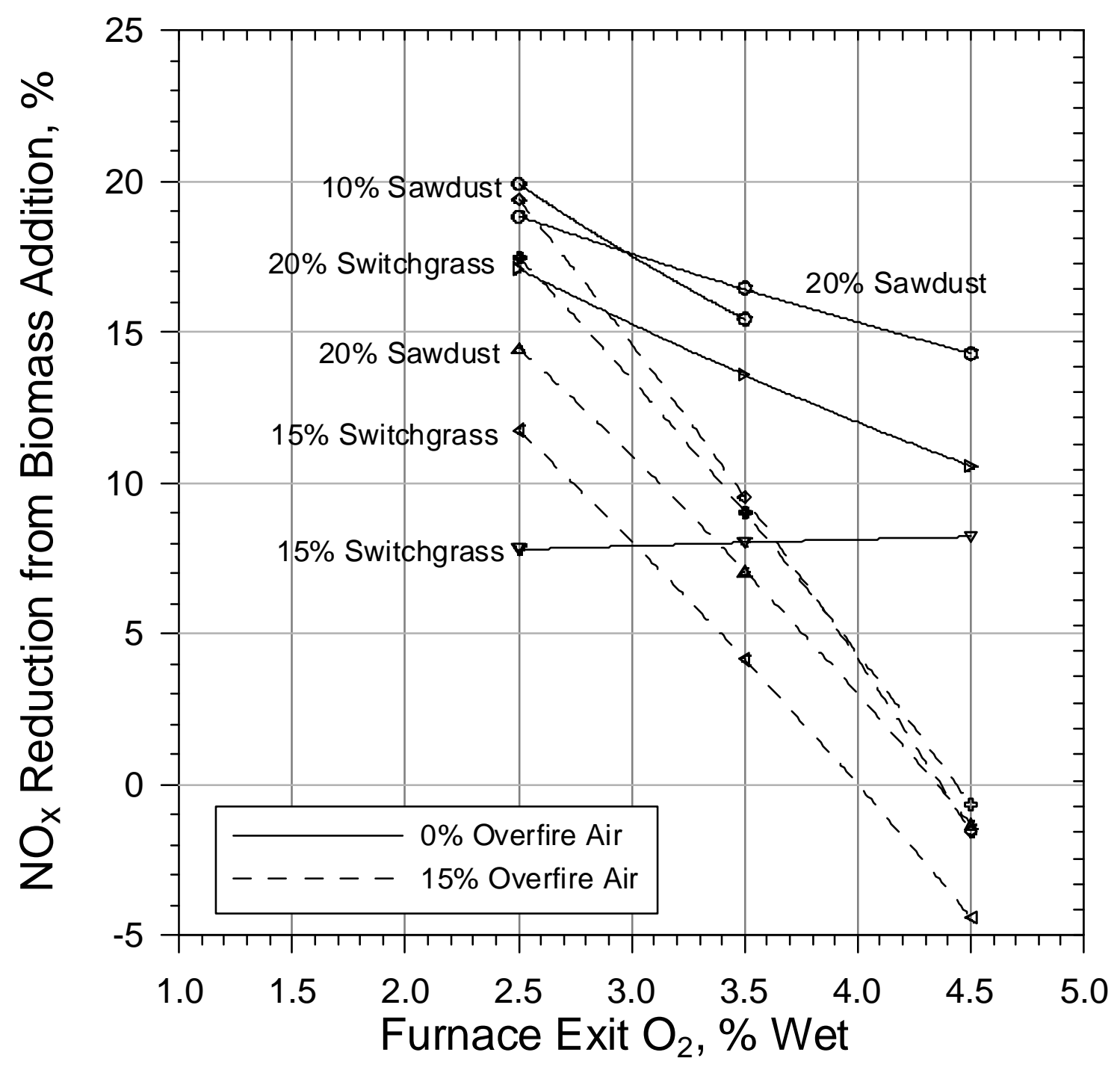

Figure 8. NOx reductions resulting from dry hardwood sawdust and switchgrass added through the center of the single-register burner as a function of furnace exit oxygen for $0 \%$ and $15 \%$ overfire air. All results for Pratt seam coal. 


\section{Pratt Seam Coal - Baseline Injection Configuration $\mathrm{NO}_{x}$ Performance in the Pilot-Scale Combustor Dependence on Furnace Exit Oxygen}

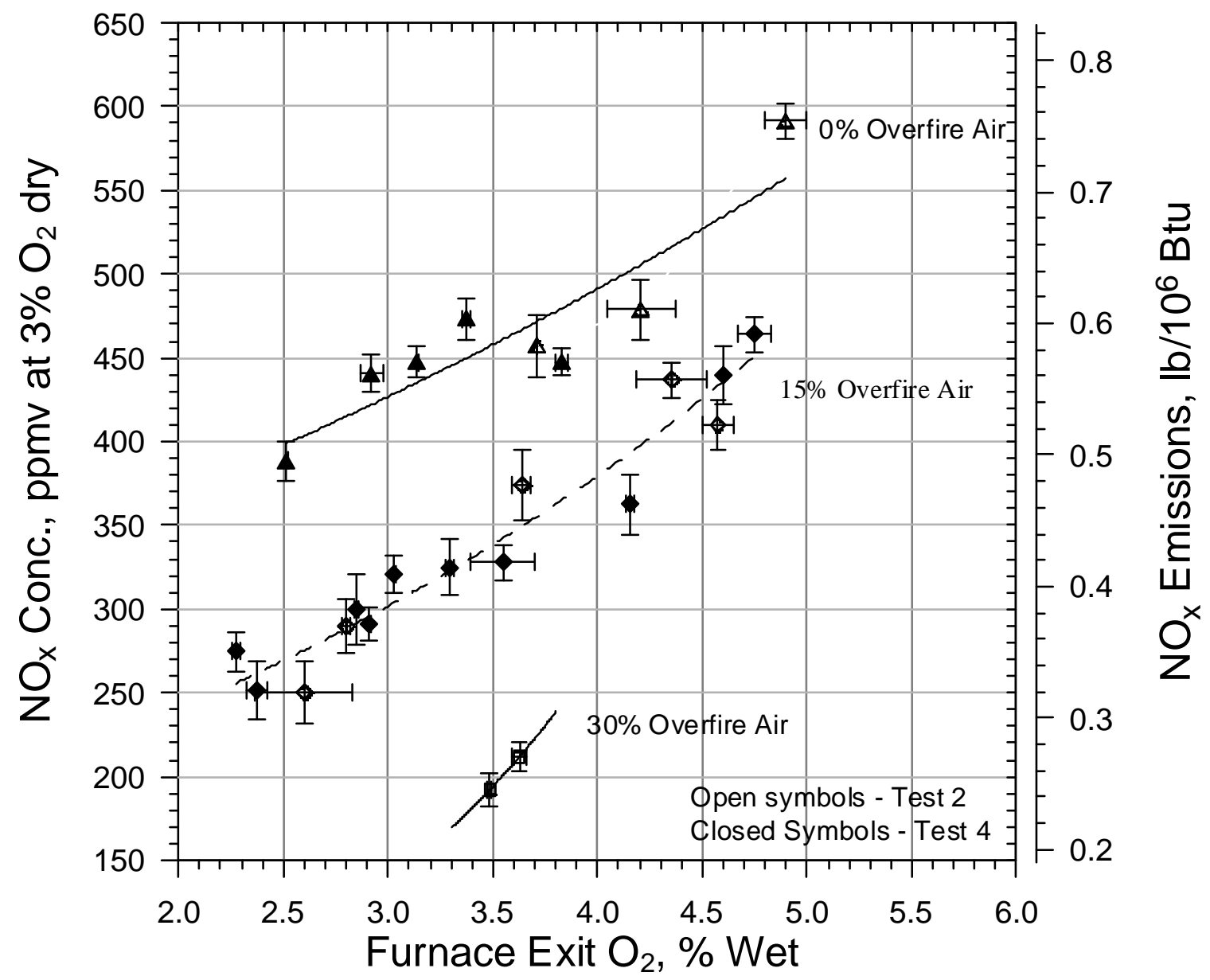

Figure 9. $100 \%$ Pratt seam coal, baseline (comilling) burner configuration. NOx emissions as a function of furnace exit oxygen for $0 \%, 15 \%$, and $30 \%$ overfire air. 
The burner was configured to baseline form, the configuration used whenever coal is comilled with biomass or when biomass is not injected through the center of the burner.

Testing was uneventful, with one exception. At 8:18 PM on June 14, a large piece of ash and slag separated from a thick, uniform ring of ash above the burner that had built up over testing. Because this object blocked the UV fire sensors, the furnace had to be brought off-line and cleaned. Testing resumed at 7AM the next day. The effect, if any, of this accretion on NOx production is being investigated.

Data from this test are still being analyzed and a comprehensive report will be presented in the next quarterly narrative.

Results Table 1 and 2, and Figures 2 through 9 summarize NOx emissions for two cofiring configurations with Pratt seam coal and various levels of sawdust and switchgrass addition at overfire air levels of $0 \%$ and $15 \%$.

Several general comments can be made:

- Compared to biomass injected through the center of the burner, NOx reductions are greatest when biomass is comilled with coal.

- NOx reduction (with co-milling) is increased with the addition of overfire air.

- NOx reduction (with center-axial injection) is greater without overfire air.

- Depending on the method of injection, significant NOx reductions can be obtained with either dry hardwood sawdust or switchgrass comilled or injected with Pratt Seam coal.

- In general, comilled biomass appears to generate lower NOx emissions than biomass injected in the center of the coal flame. 


\section{DISCUSSION}

Southern Research has provided to REI the information necessary for the production of CFD models of the combustion research facility. To date, three cases have been simulated to include the single register burner configured for testing with coal or co-milled biomass. These simulations are prerequisite to the NOx and carbon burnout modeling. The REI report on the latest simulation $(20 \%$ sawdust comilled with Pratt seam coal at $15 \%$ overfire air) is included in Appendix $B$. REl has been provided test information from Test 3 and is proceeding to model center-axial injection of $20 \%$ hardwood sawdust at $15 \%$ overfire air.

NEA has continued to make progress in the development of an innovative approach for the construction of the process model that will yield predictions of NOx emission rates and carbon burnout efficiency. This approach is being developed to help determine the system of reactors in which the CBK, Chemkin III ${ }^{\circledR}$ and bio-Flashchain ${ }^{\circledR}$ modules are used in the PC Coal Lab ${ }^{\circledR}$ calculations of NOx and unburned carbon. NEA recently recommended to REI values to use for fuel decomposition modeling. That report is inacusded in Appendix A of this quarterly narrative.

Pilot-scale tests have investigated the cofiring of sawdust and switchgrass, each mixed at two concentrations with a bituminous coal. Both comilling and the injection of biomass through the center of the burner and external to the burner have been tested. Mesa Reduction Engineering and Processing, Inc. has been retained to process all biomass that will be injected into the furnace. Further testing has just been completed where biomass was injected through one of the furnace doors to intersect the coal flame directly above the quarl (side injection into the flame). The results of those most recent tests are under review. Once we are satisfied that the data form a consistent set of results, we will continue testing with another coal (Galatia, an Illinois Basin coal) with the same biomasses repeating the three cofiring schemes tested to date. Because test results will provide the experimental data to validate the modeling approach, it is advantageous for these initial tests to be as simple cofiring cases as possible. 


\section{CONCLUSIONS}

Important progress has been made in model development and in pilot-scale furnace testing. In particular, software development for the modeling effort and an innovative approach toward defining reaction zones in a combustion system is being implemented. This development is a generally applicable algorithm that, if proven successful, should benefit other process modeling efforts in which carbon consumption or conversion is a major component. Three pilot-scale furnace tests were concluded in the third quarter and further testing is proceeding.

Expenditures have remained less than projected. Scheduling delays are partly responsible for lower billings than planned from NEA. REI expects that the CFD modeling effort will continue to experience more intense activity in the fourth quarter of CY 2001. Also, because of construction at the SRI/SCS Pilot-Scale Combustor and field test commitments, not as intensive a test schedule as was initially contemplated has been realized. However, with the completion of construction activity early in the fourth quarter of 2001, more intensive project activity is expected to ensue. In particular, with the availability of more covered storage, other biomass materials can be acquired and processed for testing.

Plans for the next quarter include continued CFD simulations by REI, Inc., continued software development to implement the equivalent reactor network analysis of the fuel-N conversion chemistry by NEA, and continued combustor runs with Galatia coal with sawdust and switchgrass. In the fifth combustor run, sawdust and switchgrass were directly injected through the side of the furnace, to intersect the coal flame. In the sixth combustor run, it is planned to comill Galatia coal with sawdust and switchgrass to determine how NOx formation is affected by the addition of these biomasses to an Illinois Basin coal. 


\section{APPENDIX A}

RECOMMENDED PARAMETER VALUES FOR FUEL DECOMPOSITION MODELING 


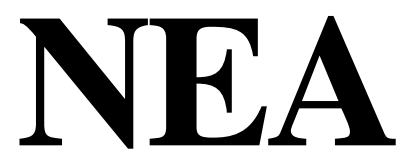

\title{
Niksa Energy Associates
}

1745 Terrace Drive, Belmont, CA 94002

Phone: (650) 6543182 Fax: (650) 6543179

e-mail: niksa@silcon.com

Second Interim Report • June 7, 2001

\section{DEVELOPMENT OF A VALIDATED MODEL FOR USE IN MINIMIZING NOx EMISSIONS AND MAXIMIZING CARBON UTILIZATION WHEN COFIRING BIOMASS WITH COAL}

\section{RECOMMENDED PARAMETER VALUES FOR FUEL DECOMPOSITION MODELING}

\author{
Prepared by: \\ Dr. Stephen Niksa \\ President
}

Prepared for:

Dr. Kevin A. Davis

Reaction Engineering International

77 West 200 South, Suite 210

Salt Lake City, UT 84101 


\section{CONTENTS}

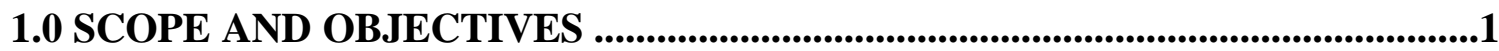

2.0 PARAMETER VALUES FOR FUEL CONVERSION IN THE CFD SIMULATIONS 1

2.1 Fuel Properties......................................................................................

2.2 Devolatilization Parameters ..................................................................2

2.3 Char Oxidation Parameters ..................................................................8

APPENDIX A - BASELINE PRODUCT DISTRIBUTIONS FOR SCS FUELS .......9 


\subsection{SCOPE AND OBJECTIVES}

This report was prepared under the research project from Southern Research Institute (SRI) to Niksa Energy Associates (NEA) entitled "Development of a Validated Model for Use in Minimizing $\mathrm{NO}_{\mathrm{X}}$ Emission and Maximizing Carbon Utilization When Cofiring Biomass with Coal." The project is using coordinated CFD simulations and calculations with detailed chemical reaction mechanisms to identify the optimal firing configuration of biomass/coal cofiring. As an important part of the coordination of these two types of calculations, NEA took responsibility for specifying the parameter values in the fuel submodels in the CFD simulations that will match the fuel decomposition behavior in the detailed reaction modeling. This report presents the parameter values and briefly explains the methodology for assigning them.

\subsection{PARAMETER VALUES FOR FUEL CONVERSION IN THE CFD}

\section{SIMULATIONS}

CFD simulations for this project are being conducted by Reaction Engineering International (REI). Their simulations, like all CFD simulations, are based on drastically simplified reaction mechanisms for devolatilization of the primary fuel, and the subsequent oxidation of its char. For devolatilization modeling, NEA was advised to use the competing, two-step reaction model (C2SM), which features two parallel first-order reactions that produce volatiles and char from a common "coal" reactant. The rate of each reaction path is based on an Arrhenius rate constant, and the selectivity between volatiles and char in each channel is represented with a fixed stoichiometric coefficient. Hence, there are six parameters in C2SM: a pseudo-frequency factor and activation energy in each rate constant $\left(\mathrm{A}_{1}, \mathrm{E}_{1}\right.$, and $\left.\mathrm{A}_{2}, \mathrm{E}_{2}\right)$ and the stoichiometric selectivity coefficients ( $y_{1}$ and $y_{2}$ ). The char oxidation rate in REI's simulations is based on a mechanism in which diffusive transport of $\mathrm{O}_{2}$ from the free stream competes with an nthorder surface reaction. In addition to the transport coefficients, this mechanism contains three parameters: the frequency factor $\left(A_{C}\right)$, activation energy $\left(E_{C}\right)$, and order $\left(n_{C}\right)$ of the

surface reaction. All these parameter values will be specified for the three fuels that have already been tested at SRI. 


\subsection{Fuel Properties}

REI and Larry Felix of Southern Company Services (SCS) provided the fuel properties in Table 2.1. The single coal is a reference fuel and blending component for the two biomass fuels. The proximate and ultimate analyses of all three fuels are typical Table 2.1 Fuel Properties.

\begin{tabular}{lcccccccccc}
\hline & \multicolumn{1}{c}{ Proximate, as rec'd wt. \% } & \multicolumn{1}{c}{ Ultimate, daf wt. \% } & \multicolumn{2}{c}{ <,$\mu \mathrm{m}$} \\
\hline & VM & FC & M & A & C & H & O & N & S & \\
Sawdust & 78.1 & 11.9 & 9.5 & 0.4 & 49.8 & 6.1 & 43.9 & 0.2 & 0.0 & 260 \\
Switch Gr. & 47.7 & 7.6 & 15.2 & 29.5 & 56.1 & 5.4 & 35.7 & 2.4 & 0.4 & 200 \\
Pratt hvA & 34.0 & 49.6 & 4.2 & 12.2 & 83.2 & 5.5 & 7.7 & 1.8 & 1.8 & 55 \\
\hline
\end{tabular}

for these fuel types. The nominal particle sizes were specified as the median value in the particle size distributions (PSDs) reported by SCS.

\subsection{Devolatilization Parameters}

We were advised to implement the procedure that is normally used by REI to specify the parameter values for the $\mathrm{C} 2 \mathrm{SM}$ devolatilization mechanism. This procedure was developed and described by Fletcher and Hardesty, based on a database of flow reactor tests at Sandia National Laboratories in the late '80s (Fletcher, T. H. and Hardesty, D. R., "Compilation of Sandia Coal Devolatilization Data, Milestone Report:, SAND92-8209, 1992). The procedure is very simple for coals, in that all bituminous have the same parameter values, which are collected in Table 2.2, below. Unfortunately, this procedure did not work with any of the fuels in this program, for reasons that are apparent in Fig. 2-1.

Since the calculations with detailed chemistry will incorporate FLASHCHAIN ${ }^{\circledR}$ as the devolatilization mechanism, we specified the C2SM parameters for REI simulations to match the FLASHCHAIN ${ }^{\circledR}$ predictions. The thermal histories imposed in these calculations are those assigned for individual particles of the mean sizes in Table 2.1 injected into gases at $1325{ }^{\circ} \mathrm{C}$ within a chamber at $725^{\circ} \mathrm{C}$. The reaction time was 30 to $50 \mathrm{~ms}$, which is long enough for all three fuels to attain their ultimate, asymptotic devolatilization yields. Two conditions were satisfied in the assignments of C2SM parameter values. First, the transient weight loss from the C2SM was matched to the FLASHCHAIN $^{\circledR}$ predictions throughout the entire thermal history. Second, the predictions were repeated for heating rates that were slower by one and two orders of 
magnitude than the base cases. This latter series ensured that the proper yields would be imposed over the range of heating rates associated with the range of sizes in the PSDs.

The baseline thermal history assigned for the Pratt hvA coal and the weight loss transients based on FLASHCHAIN ${ }^{\circledR}$, the best-fit C2SM parameters, and Fletcher's

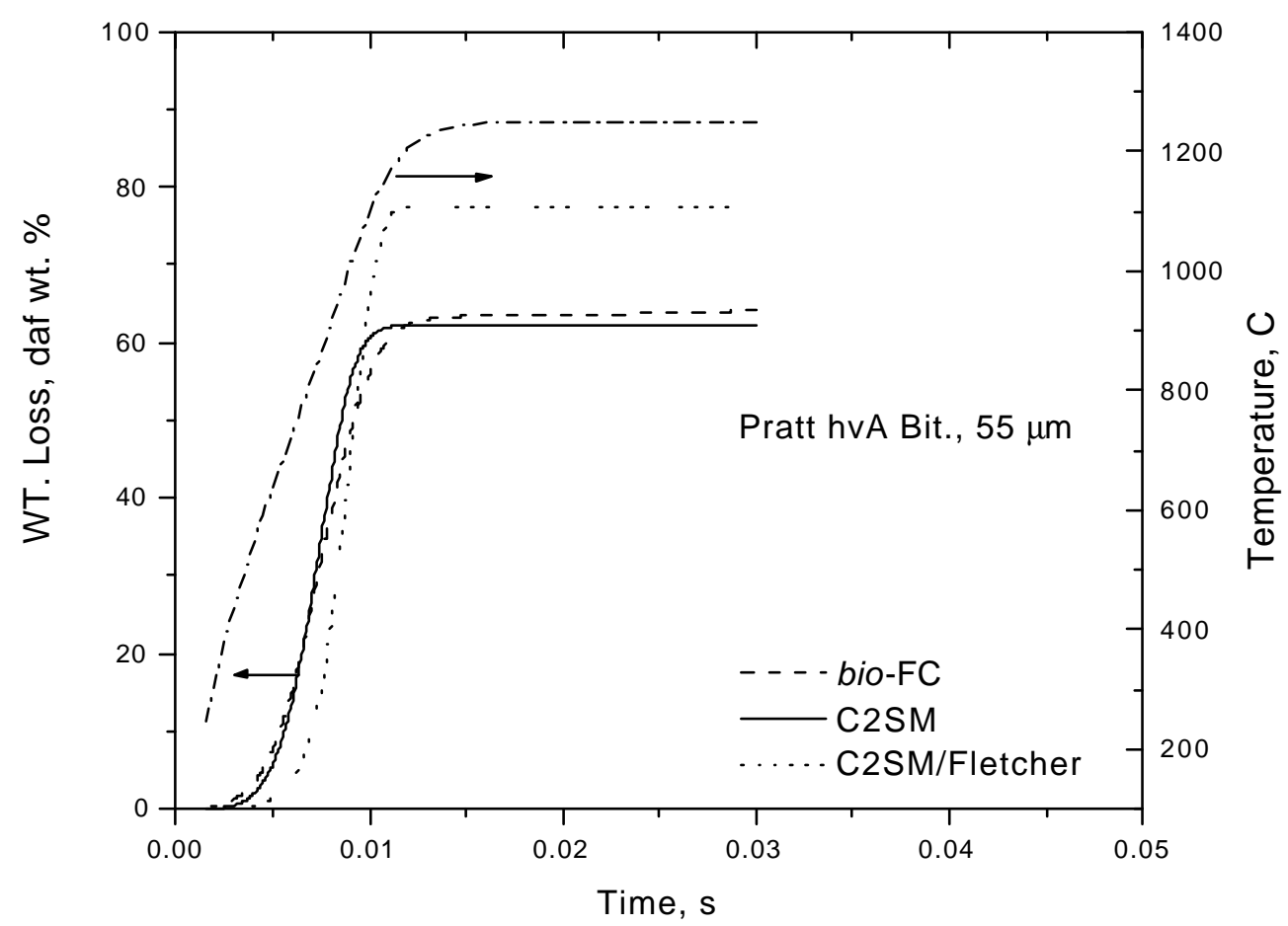

Figure 2-1. Predicted thermal history and weight loss transients from FLASHCHAIN ${ }^{\circledR}$, fit C2SM, and Fletcher's C2SM for $55 \mu \mathrm{m}$ Pratt hvA particles injected into gases at $1325^{\circ} \mathrm{C}$ within a channel at $725^{\circ} \mathrm{C}$.

parameters appear in Fig. 2-1. The nominal heating rate for the $55 \mu \mathrm{m}$ coal particles is $3.3 \times 10^{5}{ }^{\circ} \mathrm{C} / \mathrm{s}$. FLASHCHAIN ${ }^{\circledR}$ predicts complete devolatilization within $11 \mathrm{~ms}$ to an ultimate yield of 64 daf wt. \%. Both these values are consistent with expectations for this fuel type. Whereas the fit weight loss transient closely matches the FLASHCHAIN $^{\circledR}$ predictions throughout all stages of the calculations, the transient for Fletcher's parameters does not. Most important, the predicted ultimate weight loss of $77.6 \mathrm{daf} \mathrm{wt}$. $\%$ is unrealistically high. The comparison of weight loss transients for both sets of C2SM 
parameters at three heating rates in Fig. 2-2 also favors the fit parameter set. With the fit parameters, the ultimate yield falls from 64 to 56 daf wt. \% as the heating rate is reduced from $3 \times 10^{5}$ to $3 \times 10^{3}{ }^{\circ} \mathrm{C} / \mathrm{s}$. This extent of yield enhancements due to faster heating rate is quantitatively consistent with measured values for similar coal types. However, the predicted reduction of $24 \%$ for the same range of heating rates with Fletcher's C2SM parameters is too large by at least a factor of three. Consequently, Fletcher's parameters cannot be recommended for the Pratt hvA coal.

The C2SM fits for both biomass fuels appear in Figs. 2-3 through 2-6. The baseline case with switch grass in Fig. 2-3 has a heating rate that is one order of magnitude slower than the coal case, due to the larger particle size. Again we see that the fit $\mathrm{C} 2 \mathrm{SM}$ prediction matches the bio-FLASHCHAIN ${ }^{\circledR}$ predictions throughout, and that the predicted ultimate yields are the same at 85 daf wt. \%. The heating rate study in Fig. 2-4 exhibits one of the most distinctive characteristics of biomass pyrolysis; viz., that yields are not enhanced for faster heating rates as they are with coal. The predicted yields from the fit C2SM model are essentially the same over the two order of magnitude range of heating rate in the study, as they should be.

The predicted behavior for the saw dust sample in Figs. 2-5 and 2-6 is similar. The fit C2SM predictions closely match the bio-FLASHCHAIN ${ }^{\circledR}$ values throughout the baseline thermal history, and heating rate variations hardly perturb the ultimate yields.

The assigned C2SM parameter values are collected in Table 2.2 along with Fletcher's recommendations. Also, predicted distributions of secondary pyrolysis products and char compositions from bio-FLASHCHAIN for the baseline cases are collected in Appendix A. The secondary pyrolysis products are what remains after the primary products have been exposed to flame temperatures, and can be regarded as the volatile fuels that actually burn in pulverized fuel flames. 


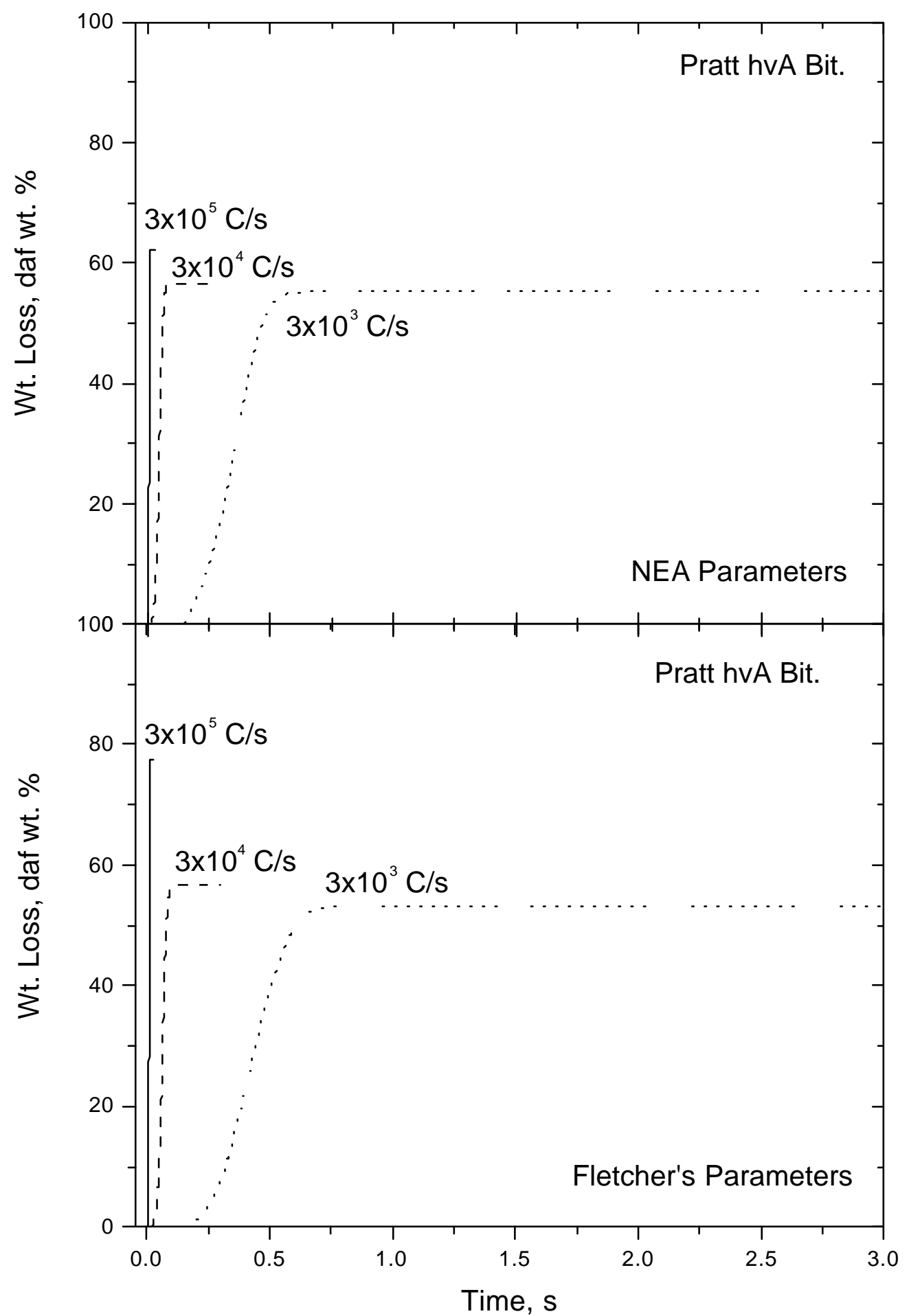

Figure 2-2. Predicted weight loss transients from the fit C2SM (top) and Fletcher's C2SM (bottom) for Pratt hvA particles injected into gases at $1325^{\circ} \mathrm{C}$ within a channel at $725^{\circ} \mathrm{C}$ to obtain three nominal heating rates. 


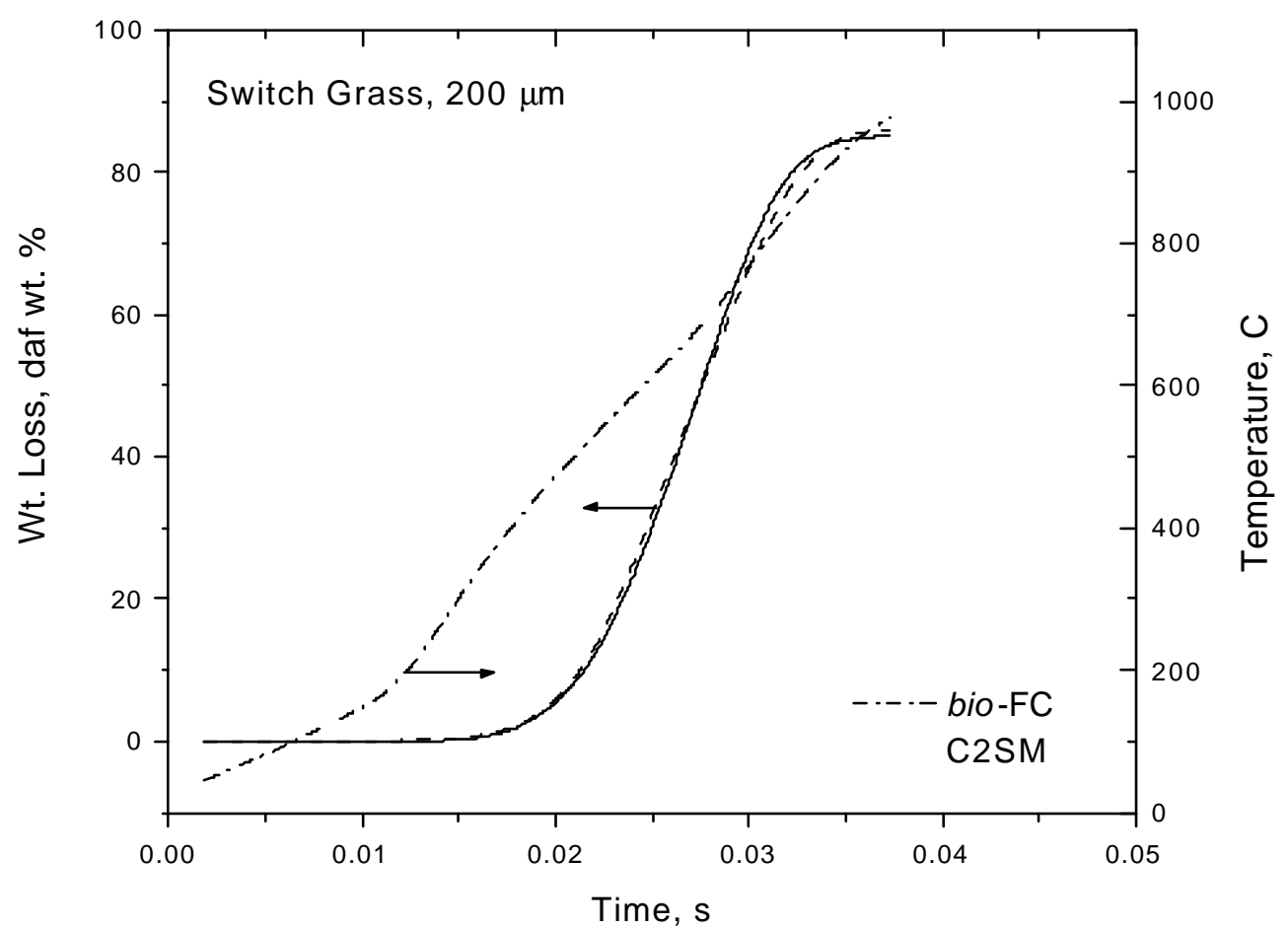

Figure 2-3. Predicted thermal history and weight loss transients from bio-FLASHCHAIN ${ }^{\circledR}$ and the fit C2SM for $200 \mu \mathrm{m}$ switch grass particles injected into gases at $1325^{\circ} \mathrm{C}$ within a channel at $725^{\circ} \mathrm{C}$.

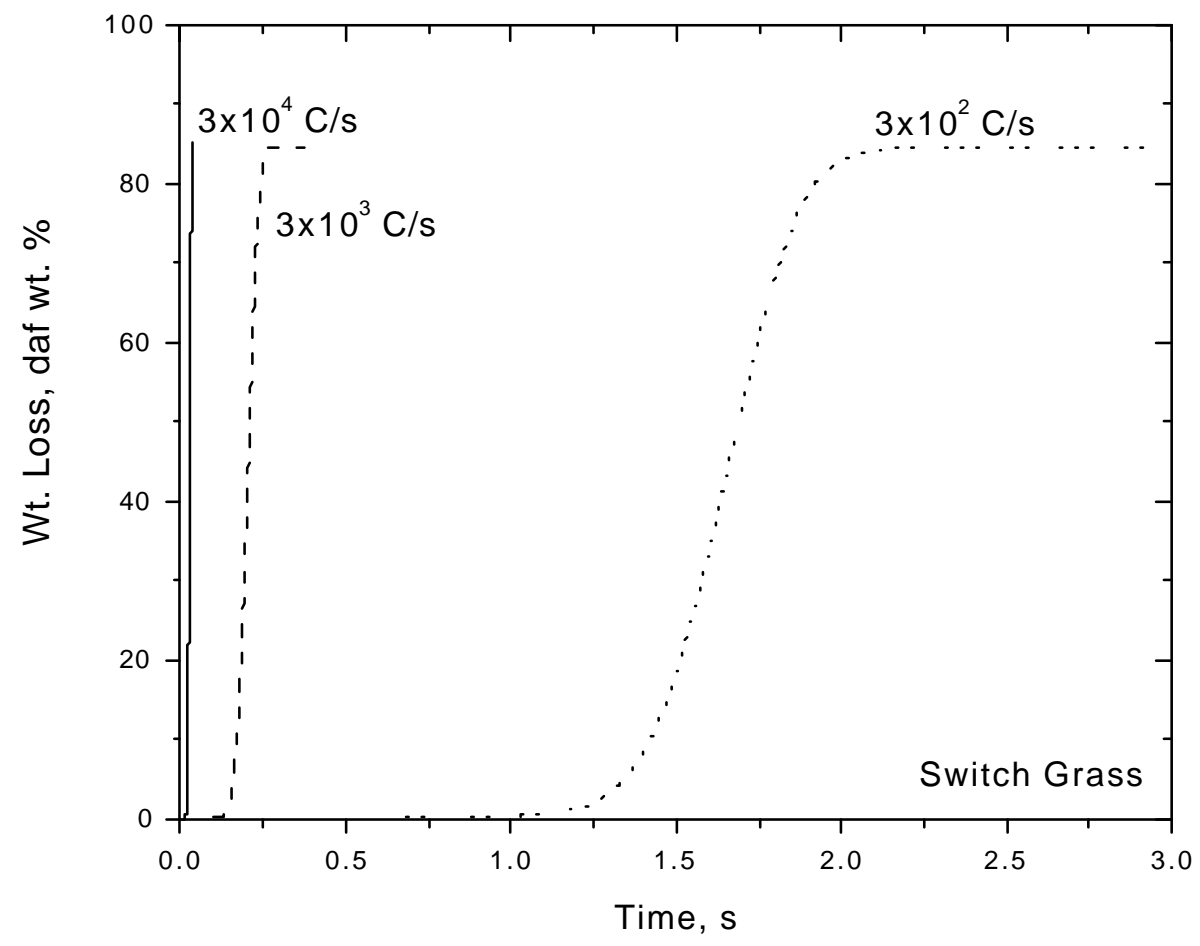

Figure 2-4. Predicted weight loss transients from the fit C2SM for switch grass injected into gases at $1325^{\circ} \mathrm{C}$ within a channel at $725^{\circ} \mathrm{C}$ to obtain three nominal heating rates. 


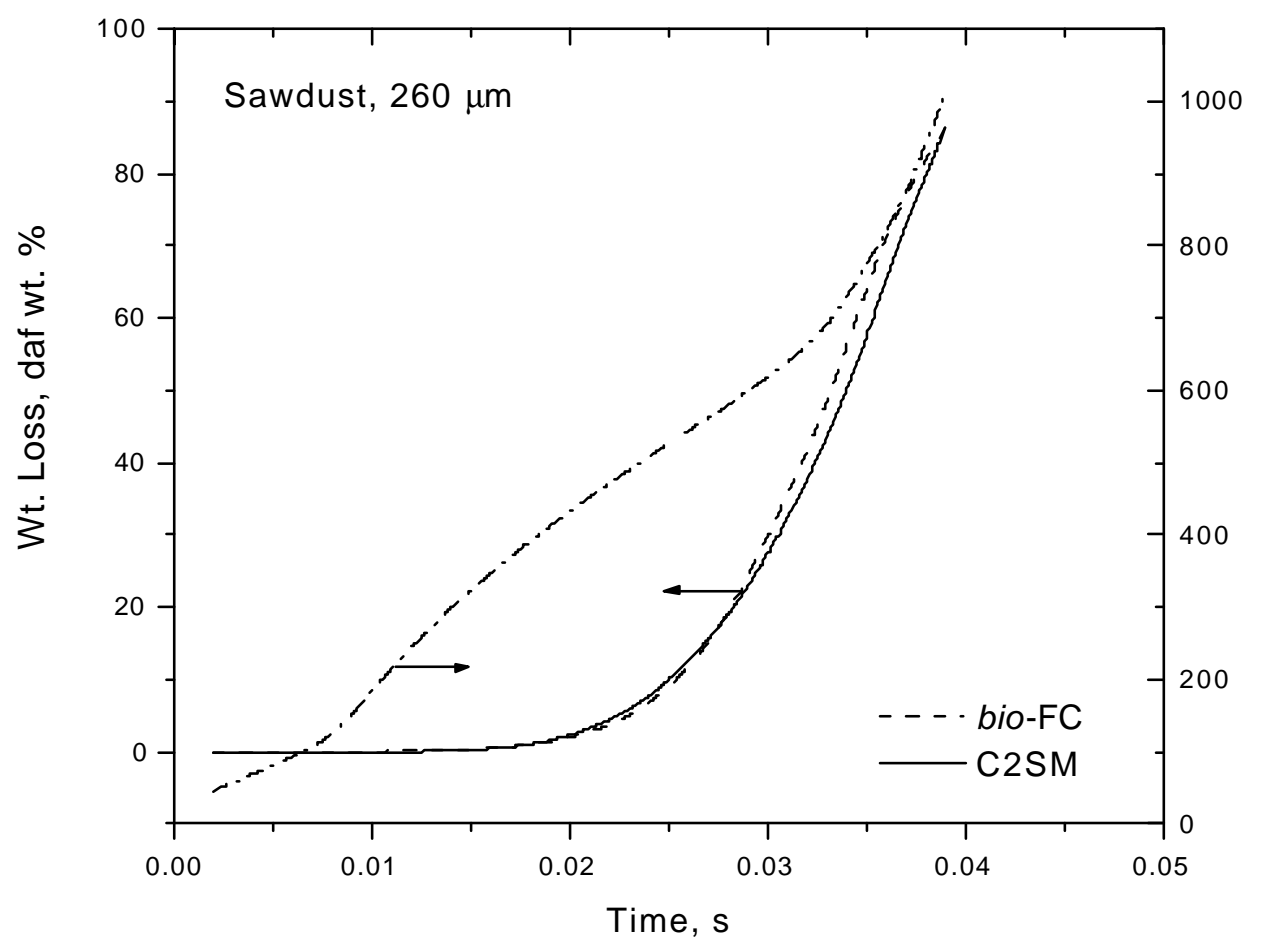

Figure 2-5. Predicted thermal history and weight loss transients from bio-FLASHCHAIN ${ }^{\circledR}$ and the fit C2SM for $260 \mu \mathrm{m}$ saw dust injected into gases at $1325^{\circ} \mathrm{C}$ within a channel at $725^{\circ} \mathrm{C}$.

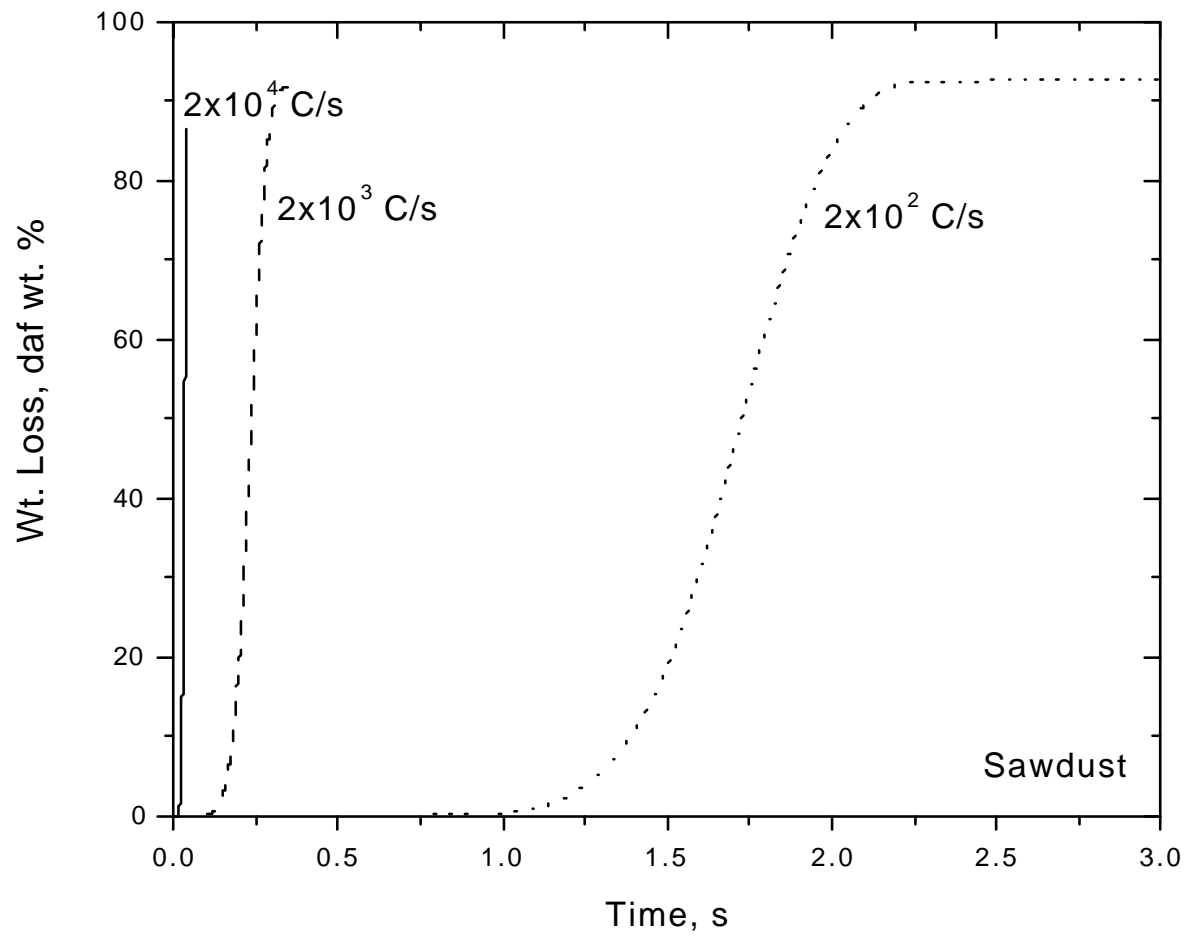

Figure 2-6. Predicted weight loss transients from the fit C2SM for saw dust injected into gases at $1325^{\circ} \mathrm{C}$ within a channel at $725^{\circ} \mathrm{C}$ to obtain three nominal heating rates. 
Table 2.2 C2SM Parameter Values. (Corrected)

\begin{tabular}{lcccccc}
\hline & $\mathrm{Y}_{1}$ & $\begin{array}{c}\mathrm{A}_{1} \\
\mathrm{~s}^{-1}\end{array}$ & $\begin{array}{c}\mathrm{E}_{1} \\
\mathrm{kcal} / \mathrm{mole}\end{array}$ & $\mathrm{Y}_{2}$ & $\begin{array}{c}\mathrm{A}_{2} \\
\mathrm{~s}^{-1}\end{array}$ & $\begin{array}{c}\mathrm{E}_{2} \\
\mathrm{kcal} / \mathrm{mole}\end{array}$ \\
\hline Sawdust & 1.00 & $1.40 \times 10^{5}$ & 14.0 & 0.70 & $1.00 \times 10^{5}$ & 15.0 \\
Switch Gr. & 0.84 & $3.60 \times 10^{5}$ & 14.0 & 1.00 & $1.30 \times 10^{5}$ & 17.0 \\
Pratt hvA & 0.55 & $1.50 \times 10^{6}$ & 17.6 & 1.00 & $7.00 \times 10^{8}$ & 35.0 \\
Fletcher & 0.53 & $3.75 \times 10^{5}$ & 17.6 & 1.00 & $1.46 \times 10^{13}$ & 60.0 \\
\hline
\end{tabular}

\subsection{Char Oxidation Parameters}

Char oxidation parameters were specified from a correlation of the Sandia char oxidation database prepared by Mitchell and Hurt, then later updated by Hurt. This database includes no biomass. However, Hurt has prepared satisfactory simulations of biomass chars by assigning rate parameters for typical subbituminous coal chars to the biomass chars, and distinctive swelling factors and particle densities. Recommended values for the three SCS fuels are collected in Table 2.3.

Table 2.3 Char Oxidation Parameter Values.

\begin{tabular}{cccccc}
\hline & $\mathrm{A}_{\mathrm{C}}, \mathrm{s}^{-1}$ & $\mathrm{E}_{\mathrm{C}}, \mathrm{kcal} /$ mole & $\mathrm{n}$ & $\mathrm{d} / \mathrm{d}_{0}$ & $\rho_{\mathrm{CHAR}}, \mathrm{g} / \mathrm{cm}^{3}$ \\
\hline Pratt hvA & 14.7 & 20 & 0.5 & 1.17 & 0.32 \\
Sawdust & 26.1 & 20 & 0.5 & 0.60 & 0.55 \\
Switch Gr. & 26.1 & 20 & 0.5 & 0.60 & 0.55 \\
\hline
\end{tabular}




\section{APPENDIX A}

Baseline product distributions for SCS fuels

A-1 
DROP TUBE SIMULATION WITH PC COAL LAB

FULL DYNAMICS

COAL CHARACTERISTICS: Pratt hvA Bituminous

\begin{tabular}{|c|c|}
\hline Ultimate & , da \\
\hline ㄷ & 83.2 \\
\hline$\frac{\circ}{\circ} \mathrm{H}$ & 5.5 \\
\hline$\div \mathrm{O}$ & 7.7 \\
\hline$\div \mathrm{N}$ & 1.8 \\
\hline$\div S$ & 1.8 \\
\hline
\end{tabular}

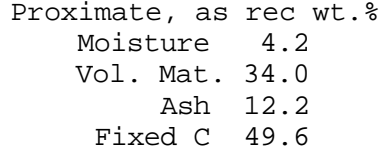

OPERATING CONDITIONS:

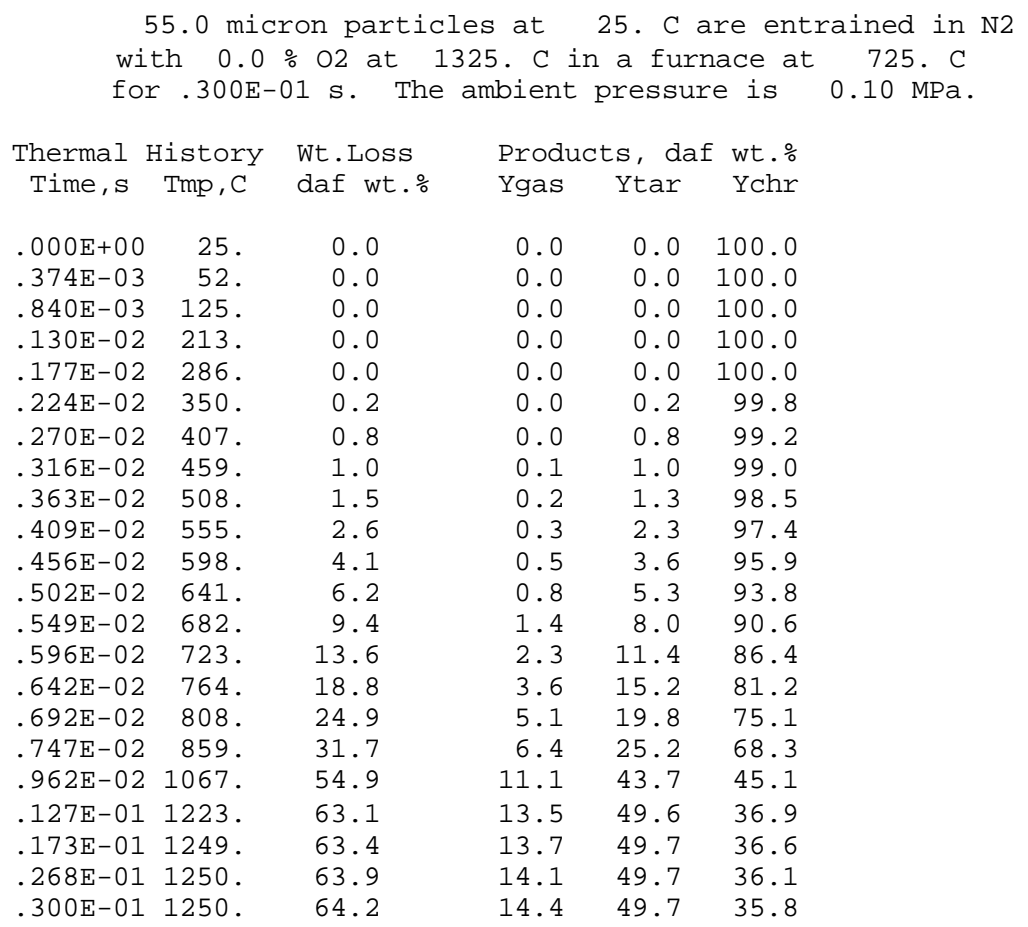


DROP TUBE SIMULATION WITH PC COAL LAB

FULL DYNAMICS

COAL CHARACTERISTICS: Pratt hvA Bituminous

$\begin{array}{cc}\text { Ultimate, daf wt. } \\ \text { ○C } & 83.2 \\ \circ \mathrm{H} & 5.5 \\ \circ \mathrm{O} & 7.7 \\ \circ \mathrm{N} & 1.8 \\ \circ \mathrm{S} & 1.8\end{array}$

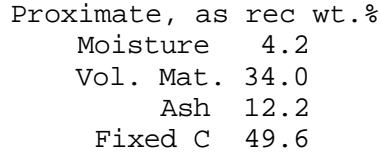

OPERATING CONDITIONS :

\begin{tabular}{|c|c|c|c|c|c|c|c|c|c|c|}
\hline \multirow{2}{*}{$\begin{array}{l}\text { Thermal } \\
\text { Time, s }\end{array}$} & \multirow{2}{*}{$\begin{array}{c}\text { History } \\
\text { Tmp, C }\end{array}$} & Wt. Loss & \multirow[b]{2}{*}{ Soot } & \multicolumn{3}{|c|}{ Secondary Pyrolysis } & \multicolumn{2}{|c|}{ Products, } & \multicolumn{2}{|c|}{ daf wt. $\%$} \\
\hline & & daf wt. $\%$ & & $\mathrm{CH} 4$ & $\mathrm{C} 2 \mathrm{H} 2$ & $\mathrm{H} 2$ & $\mathrm{CO}$ & $\mathrm{CO} 2$ & $\mathrm{H} 2 \mathrm{O}$ & $\mathrm{HCN}$ \\
\hline $.000 \mathrm{E}+00$ & 25 . & 0.0 & 0.0 & 0.0 & 0.0 & 0.00 & 0.0 & 0.0 & 0.0 & 0.00 \\
\hline $.374 \mathrm{E}-03$ & 52 . & 0.0 & 0.0 & 0.0 & 0.0 & 0.00 & 0.0 & 0.0 & 0.0 & 0.00 \\
\hline $.840 \mathrm{E}-03$ & 125 . & 0.0 & 0.0 & 0.0 & 0.0 & 0.00 & 0.0 & 0.0 & 0.0 & 0.00 \\
\hline $.130 \mathrm{E}-02$ & 213. & 0.0 & 0.0 & 0.0 & 0.0 & 0.00 & 0.0 & 0.0 & 0.0 & 0.00 \\
\hline $.177 \mathrm{E}-02$ & 286. & 0.0 & 0.0 & 0.0 & 0.0 & 0.00 & 0.0 & 0.0 & 0.0 & 0.00 \\
\hline $.224 \mathrm{E}-02$ & 350. & 0.2 & 0.2 & 0.0 & 0.0 & 0.01 & 0.0 & 0.0 & 0.0 & 0.01 \\
\hline $.270 \mathrm{E}-02$ & 407. & 0.8 & 0.7 & 0.0 & 0.0 & 0.05 & 0.0 & 0.0 & 0.0 & 0.02 \\
\hline $.316 \mathrm{E}-02$ & 459. & 1.0 & 0.9 & 0.0 & 0.0 & 0.07 & 0.0 & 0.0 & 0.0 & 0.03 \\
\hline $.363 E-02$ & 508 . & 1.5 & 1.2 & 0.0 & 0.0 & 0.10 & 0.1 & 0.0 & 0.0 & 0.04 \\
\hline $.409 \mathrm{E}-02$ & 555. & 2.6 & 2.0 & 0.0 & 0.0 & 0.16 & 0.1 & 0.0 & 0.1 & 0.06 \\
\hline $.456 \mathrm{E}-02$ & 598. & 4.1 & 3.2 & 0.0 & 0.0 & 0.27 & 0.2 & 0.1 & 0.2 & 0.09 \\
\hline $.502 \mathrm{E}-02$ & 641. & 6.2 & 4.7 & 0.0 & 0.0 & 0.40 & 0.4 & 0.1 & 0.3 & 0.13 \\
\hline $.549 \mathrm{E}-02$ & 682. & 9.4 & 7.1 & 0.0 & 0.0 & 0.61 & 0.6 & 0.2 & 0.4 & 0.20 \\
\hline $.596 \mathrm{E}-02$ & 723. & 13.6 & 10.0 & 0.1 & 0.0 & 0.88 & 1.0 & 0.3 & 0.7 & 0.28 \\
\hline $.642 \mathrm{E}-02$ & 764 . & 18.8 & 13.4 & 0.1 & 0.0 & 1.20 & 1.5 & 0.4 & 1.2 & 0.37 \\
\hline $.692 \mathrm{E}-02$ & 808 . & 24.9 & 17.5 & 0.1 & 0.0 & 1.58 & 2.1 & 0.6 & 1.6 & 0.48 \\
\hline $.747 \mathrm{E}-02$ & 859. & 31.7 & 22.3 & 0.2 & 0.0 & 2.00 & 2.6 & 0.8 & 2.0 & 0.62 \\
\hline $.962 \mathrm{E}-02$ & 21067 . & 54.9 & 39.0 & 0.3 & 0.0 & 3.51 & 4.5 & 1.3 & 3.5 & 1.11 \\
\hline $.127 \mathrm{E}-01$ & 1223 . & 63.1 & 44.3 & 0.4 & 0.2 & 4.20 & 5.1 & 1.5 & 4.1 & 1.29 \\
\hline $.173 \mathrm{E}-01$ & 1249 . & 63.4 & 44.4 & 0.4 & 0.2 & 4.21 & 5.2 & 1.5 & 4.1 & 1.38 \\
\hline $.268 \mathrm{E}-01$ & 1250 . & 63.9 & 44.4 & 0.4 & 0.2 & 4.21 & 5.2 & 1.5 & 4.1 & 1.82 \\
\hline $.300 \mathrm{E}-01$ & 1250 . & 64.2 & 44.4 & 0.4 & 0.2 & 4.21 & 5.2 & 1.5 & 4.1 & 2.10 \\
\hline
\end{tabular}


DROP TUBE SIMULATION WITH PC COAL LAB

FULL DYNAMICS

COAL CHARACTERISTICS: Pratt hvA Bituminous

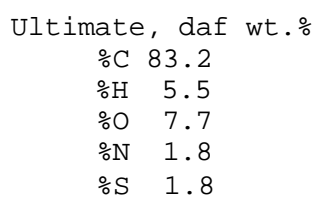

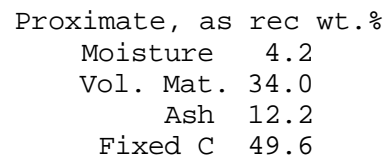

OPERATING CONDITIONS:

\begin{tabular}{|c|c|c|c|c|c|c|c|}
\hline History & Wt. Loss & & Char & Comp & sition, & daf & wt. $\%$ \\
\hline Tmp, C & daf wt. $\%$ & Ychar & $\div \mathrm{C}$ & $\circ \mathrm{H}$ & $\div 0$ & $\div \mathrm{N}$ & $\div \mathrm{S}$ \\
\hline 25 . & 0.0 & 100.0 & 83.2 & 5.5 & 7.7 & 1.8 & 1.8 \\
\hline 52 . & 0.0 & 100.0 & 83.2 & 5.5 & 7.7 & 1.8 & 1.8 \\
\hline 125 . & 0.0 & 100.0 & 83.2 & 5.5 & 7.7 & 1.8 & 1.8 \\
\hline 213. & 0.0 & 100.0 & 83.2 & 5.5 & 7.7 & 1.8 & 1.8 \\
\hline 286. & 0.0 & 100.0 & 83.2 & 5.5 & 7.7 & 1.8 & 1.8 \\
\hline 350. & 0.2 & 99.8 & 83.2 & 5.5 & 7.7 & 1.8 & 1.8 \\
\hline 407 . & 0.8 & 99.2 & 83.2 & 5.5 & 7.7 & 1.8 & 1.8 \\
\hline 459. & 1.0 & 99.0 & 83.3 & 5.5 & 7.7 & 1.8 & 1.8 \\
\hline 508 . & 1.5 & 98.5 & 83.3 & 5.5 & 7.6 & 1.8 & 1.8 \\
\hline 555. & 2.6 & 97.4 & 83.4 & 5.5 & 7.6 & 1.8 & 1.8 \\
\hline 598. & 4.1 & 95.9 & 83.5 & 5.4 & 7.5 & 1.8 & 1.8 \\
\hline 641. & 6.2 & 93.8 & 83.7 & 5.4 & 7.4 & 1.8 & 1.7 \\
\hline 682. & 9.4 & 90.6 & 84.0 & 5.3 & 7.2 & 1.8 & 1.7 \\
\hline 723. & 13.6 & 86.4 & 84.6 & 5.2 & 6.8 & 1.8 & 1.6 \\
\hline 764 . & 18.8 & 81.2 & 85.4 & 4.9 & 6.3 & 1.9 & 1.5 \\
\hline 808 . & 24.9 & 75.1 & 86.5 & 4.7 & 5.6 & 1.9 & 1.3 \\
\hline 859. & 31.7 & 68.3 & 87.5 & 4.3 & 5.0 & 1.9 & 1.2 \\
\hline 1067 . & 54.9 & 45.1 & 92.9 & 2.3 & 2.2 & 2.1 & 0.5 \\
\hline 1223 . & 63.1 & 36.9 & 96.9 & 0.6 & 0.2 & 2.2 & 0.1 \\
\hline 1249 . & 63.4 & 36.6 & 97.1 & 0.6 & 0.0 & 2.2 & 0.1 \\
\hline 1250 . & 63.9 & 36.1 & 97.7 & 0.6 & 0.0 & 1.6 & 0.1 \\
\hline 1250 . & 64.2 & 35.8 & 98.1 & 0.6 & 0.0 & 1.2 & 0.1 \\
\hline
\end{tabular}


DROP TUBE SIMULATION WITH PC COAL LAB

FULL DYNAMICS

BIOMASS CHARACTERISTICS: Switch Grass

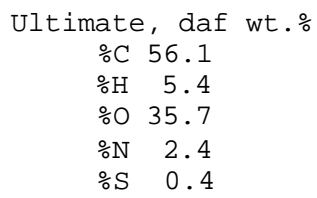

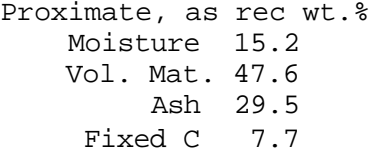

OPERATING CONDITIONS :

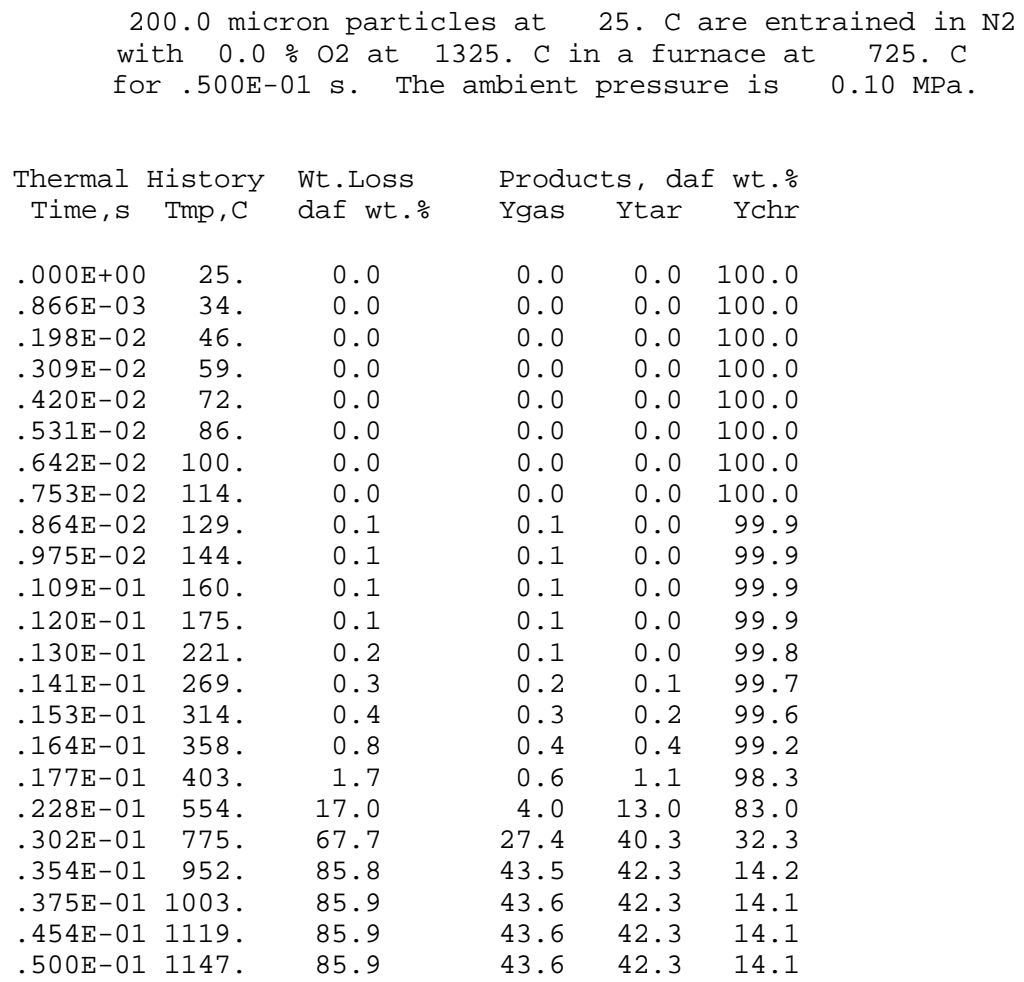


DROP TUBE SIMULATION WITH PC COAL LAB

FULL DYNAMICS

BIOMASS CHARACTERISTICS: Switch Grass

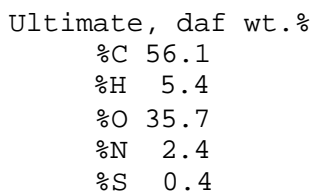

OPERATING CONDITIONS :

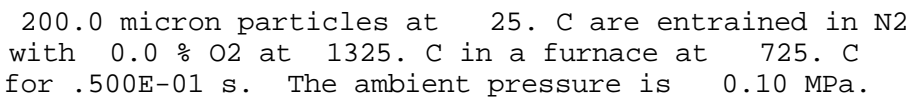

\begin{tabular}{|c|c|c|c|c|c|c|c|c|c|c|c|}
\hline Thermal & History & Wt. Loss & & & ry & 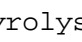 & 2 & ts, & $\mathrm{ff}$ & & \\
\hline Time, s & Tmp, C & daf wt. $\%$ & Soot & $\mathrm{CH} 4$ & $\mathrm{C} 2 \mathrm{H} 2$ & $\mathrm{C} 2 \mathrm{H} 4$ & $\mathrm{H} 2$ & $\mathrm{CO}$ & $\mathrm{CO} 2$ & $\mathrm{H} 2 \mathrm{O}$ & NH3 \\
\hline $.000 \mathrm{E}+00$ & 25 . & 0.0 & 0.0 & 0.0 & 0.0 & 0.0 & 0.00 & 0.0 & 0.0 & 0.0 & 0.00 \\
\hline $.866 \mathrm{E}-03$ & 34 . & 0.0 & 0.0 & 0.0 & 0.0 & 0.0 & 0.00 & 0.0 & 0.0 & 0.0 & 0.00 \\
\hline $.198 \mathrm{E}-02$ & 46. & 0.0 & 0.0 & 0.0 & 0.0 & 0.0 & 0.00 & 0.0 & 0.0 & 0.0 & 0.00 \\
\hline $.309 E-02$ & 59. & 0.0 & 0.0 & 0.0 & 0.0 & 0.0 & 0.00 & 0.0 & 0.0 & 0.0 & 0.00 \\
\hline $.420 \mathrm{E}-02$ & 72. & 0.0 & 0.0 & 0.0 & 0.0 & 0.0 & 0.00 & 0.0 & 0.0 & 0.0 & 0.00 \\
\hline $.531 E-02$ & 86. & 0.0 & 0.0 & 0.0 & 0.0 & 0.0 & 0.00 & 0.0 & 0.0 & 0.0 & 0.00 \\
\hline $.642 E-02$ & 100. & 0.0 & 0.0 & 0.0 & 0.0 & 0.0 & 0.00 & 0.0 & 0.0 & 0.0 & 0.00 \\
\hline $.753 E-02$ & 114 . & 0.0 & 0.0 & 0.0 & 0.0 & 0.0 & 0.00 & 0.0 & 0.0 & 0.0 & 0.00 \\
\hline $.864 \mathrm{E}-02$ & 129. & 0.1 & 0.0 & 0.0 & 0.0 & 0.0 & 0.00 & 0.0 & 0.0 & 0.0 & 0.00 \\
\hline $.975 \mathrm{E}-02$ & 144 . & 0.1 & 0.0 & 0.0 & 0.0 & 0.0 & 0.00 & 0.0 & 0.0 & 0.0 & 0.00 \\
\hline $.109 \mathrm{E}-01$ & 160. & 0.1 & 0.0 & 0.0 & 0.0 & 0.0 & 0.00 & 0.0 & 0.0 & 0.1 & 0.00 \\
\hline $.120 \mathrm{E}-01$ & 175 . & 0.1 & 0.0 & 0.0 & 0.0 & 0.0 & 0.00 & 0.0 & 0.0 & 0.1 & 0.00 \\
\hline $.130 \mathrm{E}-01$ & 221 . & 0.2 & 0.0 & 0.0 & 0.0 & 0.0 & 0.00 & 0.0 & 0.0 & 0.1 & 0.00 \\
\hline $.141 \mathrm{E}-01$ & 269 . & 0.3 & 0.0 & 0.0 & 0.0 & 0.0 & 0.00 & 0.1 & 0.0 & 0.1 & 0.00 \\
\hline $.153 E-01$ & 314 . & 0.4 & 0.1 & 0.0 & 0.0 & 0.0 & 0.00 & 0.1 & 0.0 & 0.2 & 0.01 \\
\hline $.164 \mathrm{E}-01$ & 358. & 0.8 & 0.1 & 0.1 & 0.0 & 0.0 & 0.01 & 0.2 & 0.0 & 0.3 & 0.02 \\
\hline $.177 \mathrm{E}-01$ & 403. & 1.7 & 0.3 & 0.2 & 0.0 & 0.0 & 0.02 & 0.6 & 0.1 & 0.4 & 0.05 \\
\hline $.228 \mathrm{E}-01$ & 554. & 17.0 & 3.6 & 1.4 & 0.0 & 0.5 & 0.27 & 6.8 & 2.0 & 1.6 & 0.74 \\
\hline $.302 E-01$ & 775 . & 67.7 & 12.2 & 6.0 & 0.5 & 1.5 & 1.28 & 30.5 & 6.9 & 5.7 & 2.47 \\
\hline $.354 \mathrm{E}-01$ & 952 . & 85.8 & 13.3 & 7.4 & 1.3 & 1.5 & 1.70 & 41.4 & 8.0 & 7.8 & 2.88 \\
\hline $.375 \mathrm{E}-01$ & 1003. & 85.9 & 13.3 & 7.4 & 1.3 & 1.5 & 1.70 & 41.5 & 8.0 & 7.8 & 2.88 \\
\hline $.454 \mathrm{E}-01$ & 1119. & 85.9 & 13.3 & 7.4 & 1.3 & 1.5 & 1.70 & 41.5 & 8.0 & 7.8 & 2.88 \\
\hline $500 \mathrm{E}-01$ & 1147 . & 85.9 & 13.3 & 7.4 & 1.3 & 1.5 & 1.70 & 41.5 & 8.0 & 7.8 & 2.88 \\
\hline
\end{tabular}


DROP TUBE SIMULATION WITH PC COAL LAB

FULL DYNAMICS

BIOMASS CHARACTERISTICS: Switch Grass

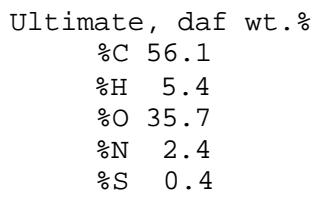

OPERATING CONDITIONS:

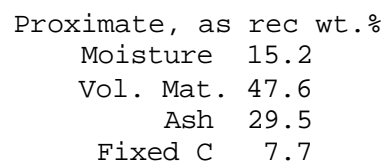

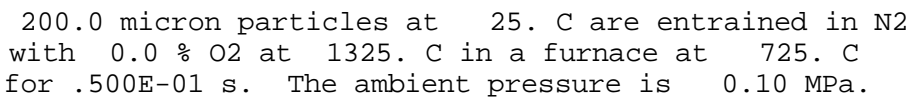


DROP TUBE SIMULATION WITH PC COAL LAB

FULL DYNAMICS

BIOMASS CHARACTERISTICS: Sawdust

$\begin{array}{cr}\text { Ultimate, daf wt. } \\ \text { ○C } & 49.8 \\ \circ \mathrm{H} & 6.1 \\ \circ \mathrm{O} & 43.9 \\ \circ \mathrm{N} & 0.2 \\ \circ \mathrm{S} & 0.0\end{array}$

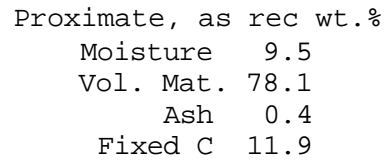

OPERATING CONDITIONS:

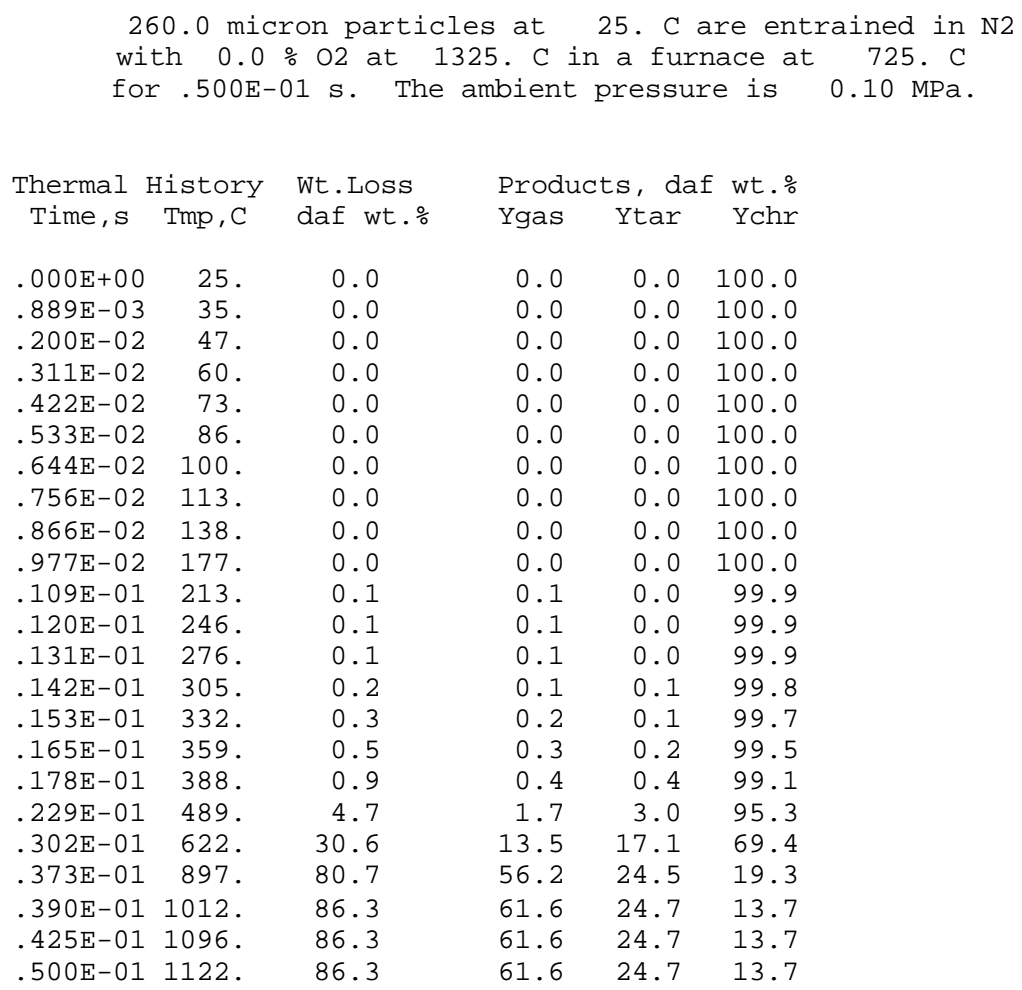


DROP TUBE SIMULATION WITH PC COAL LAB

FULL DYNAMICS

BIOMASS CHARACTERISTICS: Sawdust

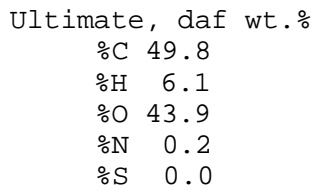

OPERATING CONDITIONS :

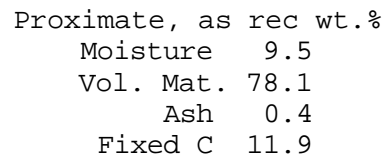

260.0 micron particles at 25 . C are entrained in N2
with $0.0 \% 02$ at 1325 . C in a furnace at 725 . C
for.500E-01 s. The ambient pressure is $0.10 \mathrm{MPa}$.

\begin{tabular}{|c|c|c|c|c|c|c|c|c|c|c|c|}
\hline Thermal & History & Wt. Loss & & 8000 & $\operatorname{ary}$ & (y & $\operatorname{Pr}$ & ts, & $\mathrm{f}$ & & \\
\hline Time, s & Tmp, C & daf wt. $\%$ & Soot & $\mathrm{CH} 4$ & $\mathrm{C} 2 \mathrm{H} 2$ & $\mathrm{C} 2 \mathrm{H} 4$ & $\mathrm{H} 2$ & $\mathrm{CO}$ & $\mathrm{CO} 2$ & $\mathrm{H} 2 \mathrm{O}$ & NH3 \\
\hline $.000 \mathrm{E}+00$ & 25 . & 0.0 & 0.0 & 0.0 & 0.0 & 0.0 & 0.00 & 0.0 & 0.0 & 0.0 & 0.00 \\
\hline $.889 E-03$ & 35 . & 0.0 & 0.0 & 0.0 & 0.0 & 0.0 & 0.00 & 0.0 & 0.0 & 0.0 & 0.00 \\
\hline $.200 E-02$ & 47. & 0.0 & 0.0 & 0.0 & 0.0 & 0.0 & 0.00 & 0.0 & 0.0 & 0.0 & 0.00 \\
\hline $.311 E-02$ & 60. & 0.0 & 0.0 & 0.0 & 0.0 & 0.0 & 0.00 & 0.0 & 0.0 & 0.0 & 0.00 \\
\hline $.422 E-02$ & 73. & 0.0 & 0.0 & 0.0 & 0.0 & 0.0 & 0.00 & 0.0 & 0.0 & 0.0 & 0.00 \\
\hline $.533 E-02$ & 86. & 0.0 & 0.0 & 0.0 & 0.0 & 0.0 & 0.00 & 0.0 & 0.0 & 0.0 & 0.00 \\
\hline $.644 \mathrm{E}-02$ & 100. & 0.0 & 0.0 & 0.0 & 0.0 & 0.0 & 0.00 & 0.0 & 0.0 & 0.0 & 0.00 \\
\hline $.756 \mathrm{E}-02$ & 113. & 0.0 & 0.0 & 0.0 & 0.0 & 0.0 & 0.00 & 0.0 & 0.0 & 0.0 & 0.00 \\
\hline $.866 E-02$ & 138. & 0.0 & 0.0 & 0.0 & 0.0 & 0.0 & 0.00 & 0.0 & 0.0 & 0.0 & 0.00 \\
\hline $.977 E-02$ & 177. & 0.0 & 0.0 & 0.0 & 0.0 & 0.0 & 0.00 & 0.0 & 0.0 & 0.0 & 0.00 \\
\hline $.109 \mathrm{E}-01$ & 213. & 0.1 & 0.0 & 0.0 & 0.0 & 0.0 & 0.00 & 0.0 & 0.0 & 0.0 & 0.00 \\
\hline $.120 \mathrm{E}-01$ & 246 . & 0.1 & 0.0 & 0.0 & 0.0 & 0.0 & 0.00 & 0.0 & 0.0 & 0.1 & 0.00 \\
\hline $.131 E-01$ & 276 . & 0.1 & 0.0 & 0.0 & 0.0 & 0.0 & 0.00 & 0.0 & 0.0 & 0.1 & 0.00 \\
\hline $.142 \mathrm{E}-01$ & 305 . & 0.2 & 0.0 & 0.0 & 0.0 & 0.0 & 0.00 & 0.1 & 0.0 & 0.1 & 0.00 \\
\hline $.153 E-01$ & 332 . & 0.3 & 0.0 & 0.0 & 0.0 & 0.0 & 0.00 & 0.1 & 0.0 & 0.1 & 0.00 \\
\hline $.165 \mathrm{E}-01$ & 359. & 0.5 & 0.0 & 0.0 & 0.0 & 0.0 & 0.00 & 0.2 & 0.0 & 0.2 & 0.00 \\
\hline $.178 \mathrm{E}-01$ & 388. & 0.9 & 0.1 & 0.1 & 0.0 & 0.0 & 0.01 & 0.3 & 0.1 & 0.3 & 0.00 \\
\hline $.229 \mathrm{E}-01$ & 489. & 4.7 & 0.4 & 0.5 & 0.0 & 0.2 & 0.06 & 2.0 & 0.6 & 0.9 & 0.02 \\
\hline $.302 \mathrm{E}-01$ & 622 . & 30.6 & 2.4 & 2.9 & 0.2 & 1.1 & 0.59 & 14.8 & 4.0 & 4.4 & 0.11 \\
\hline $.373 E-01$ & 897. & 80.7 & 4.2 & 6.7 & 1.9 & 1.4 & 1.97 & 44.8 & 7.9 & 11.4 & 0.23 \\
\hline $.390 E-01$ & 1012 . & 86.3 & 4.3 & 7.1 & 2.2 & 1.4 & 2.14 & 48.5 & 8.2 & 12.1 & 0.24 \\
\hline $.425 E-01$ & 1096. & 86.3 & 4.3 & 7.1 & 2.2 & 1.4 & 2.14 & 48.5 & 8.2 & 12.1 & 0.24 \\
\hline $.500 \mathrm{E}-01$ & 1122 & 86.3 & 4.3 & 7.1 & 2.2 & 1.4 & 2.14 & 48.5 & 8.2 & 12.1 & 0.24 \\
\hline
\end{tabular}


DROP TUBE SIMULATION WITH PC COAL LAB

FULL DYNAMICS

BIOMASS CHARACTERISTICS:

\begin{tabular}{|c|c|}
\hline Ultimate, & daf \\
\hline$\therefore \mathrm{C} 4 \mathrm{~S}$ & 49.8 \\
\hline$\circ \mathrm{H} \quad 6$ & 6.1 \\
\hline$\therefore 43$ & 43.9 \\
\hline$\because \mathrm{N}$ & 0.2 \\
\hline$\because 5$ & 0.0 \\
\hline
\end{tabular}

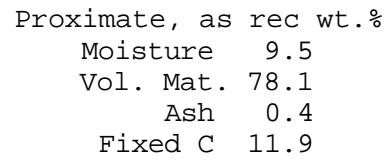

OPERATING CONDITIONS:

260.0 micron particles at 25. C are entrained in N2 with $0.0 \div 02$ at 1325. C in a furnace at 725. C for . 500E-01 s. The ambient pressure is $0.10 \mathrm{MPa}$.

\begin{tabular}{|c|c|c|c|c|c|c|c|c|}
\hline $\mathrm{mal}$ & $\mathrm{Hi}$ & Wt Toss & & Char & Comp & osition, & daf & wt. $\frac{\circ}{0}$ \\
\hline Time, $\mathrm{s}$ & Tmp, C & daf wt. $\%$ & Ychar & $\div \mathrm{C}$ & $\div \mathrm{H}$ & $\div 0$ & $\div \mathrm{N}$ & $\div 5$ \\
\hline $000 \mathrm{E}+00$ & 25 . & 0.0 & 100.0 & 49.8 & 6.1 & 43.9 & 0.2 & 0.0 \\
\hline $.889 \mathrm{E}-03$ & 35. & 0.0 & 100.0 & 49.8 & 6.1 & 43.9 & 0.2 & 0.0 \\
\hline $.200 \mathrm{E}-02$ & 47. & 0.0 & 100.0 & 49.8 & 6.1 & 43.9 & 0.2 & 0.0 \\
\hline $.311 \mathrm{E}-02$ & 60. & 0.0 & 100.0 & 49.8 & 6.1 & 43.9 & 0.2 & 0.0 \\
\hline $.422 \mathrm{E}-02$ & 73. & 0.0 & 100.0 & 49.8 & 6.1 & 43.9 & 0.2 & 0.0 \\
\hline $.533 E-02$ & 86. & 0.0 & 100.0 & 49.8 & 6.1 & 43.9 & 0.2 & 0.0 \\
\hline $.644 \mathrm{E}-02$ & 100. & 0.0 & 100.0 & 49.8 & 6.1 & 43.9 & 0.2 & 0.0 \\
\hline $.756 \mathrm{E}-02$ & 113. & 0.0 & 100.0 & 49.8 & 6.1 & 43.9 & 0.2 & 0.0 \\
\hline $.866 \mathrm{E}-02$ & 138. & 0.0 & 100.0 & 49.8 & 6.1 & 43.9 & 0.2 & 0.0 \\
\hline $.977 \mathrm{E}-02$ & 177. & 0.0 & 100.0 & 49.8 & 6.1 & 43.9 & 0.2 & 0.0 \\
\hline $.109 \mathrm{E}-01$ & 213. & 0.1 & 99.9 & 49.9 & 6.1 & 43.9 & 0.2 & 0.0 \\
\hline $.120 \mathrm{E}-01$ & 246. & 0.1 & 99.9 & 49.9 & 6.1 & 43.8 & 0.2 & 0.0 \\
\hline $.131 \mathrm{E}-01$ & 276. & 0.1 & 99.9 & 49.9 & 6.1 & 43.8 & 0.2 & 0.0 \\
\hline $.142 \mathrm{E}-01$ & 305. & 0.2 & 99.8 & 49.9 & 6.1 & 43.8 & 0.2 & 0.0 \\
\hline $.153 \mathrm{E}-01$ & 332 . & 0.3 & 99.7 & 49.9 & 6.1 & 43.8 & 0.2 & 0.0 \\
\hline $.165 \mathrm{E}-01$ & 359. & 0.5 & 99.5 & 49.9 & 6.1 & 43.8 & 0.2 & 0.0 \\
\hline $.178 \mathrm{E}-01$ & 388. & 0.9 & 99.1 & 50.0 & 6.1 & 43.7 & 0.2 & 0.0 \\
\hline $.229 \mathrm{E}-01$ & 489. & 4.7 & 95.3 & 50.4 & 6.1 & 43.3 & 0.2 & 0.0 \\
\hline $.302 \mathrm{E}-01$ & 622. & 30.6 & 69.4 & 54.0 & 5.9 & 40.0 & 0.2 & 0.0 \\
\hline $.373 E-01$ & 897. & 80.7 & 19.3 & 78.1 & 4.2 & 17.6 & 0.0 & 0.0 \\
\hline $.390 \mathrm{E}-01$ & 11012 . & 86.3 & 13.7 & 95.3 & 3.3 & 1.4 & 0.0 & 0.0 \\
\hline $.425 \mathrm{E}-01$ & 11096. & 86.3 & 13.7 & 95.3 & 3.3 & 1.4 & 0.0 & 0.0 \\
\hline $.500 \mathrm{E}-01$ & 11122 . & 86.3 & 13.7 & 95.3 & 3.3 & 1.4 & 0.0 & 0.0 \\
\hline
\end{tabular}




\section{APPENDIX B}

Report of CFD simulation completed by REI, Inc. 


\title{
Southern Research Institute Biomass Co-firing Update
}

\author{
Reaction Engineering International
}

June 14, 2001

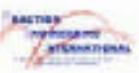

\section{Summary}

- Co-milled case (20\% Sawdust- $80 \%$ Pratt seam coal) was simulated using GLACIER

- Burnout level is 0.99

- Lower temperature at furnace section 5 \& 7 than coal only case (different operating condition but with similar furnace exit $\mathrm{O}_{2}$ concentration)

- Stoichiometric ratio calculation algorithm was implemented into the codes as Stephen Niksa had requested. 


\section{0\% Sawdust $80 \%$ Pratt Seam Coal}

- Particle size distribution

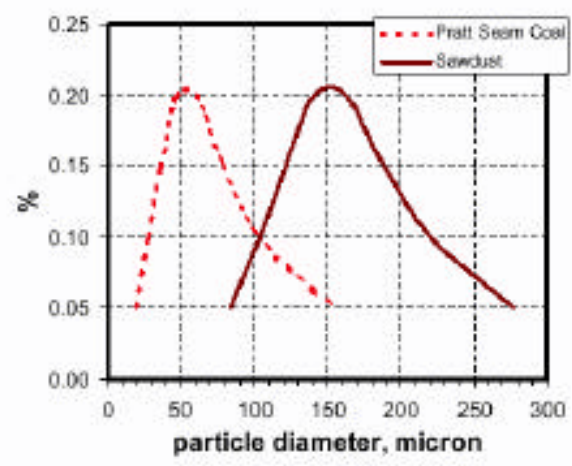

- Ultimate analysis

\begin{tabular}{cccc} 
& Pratt Seam Coal & Sawdust & Blend \\
\hline $\mathrm{C}$ & 69.51 & 4.4 .85 & 64.58 \\
$\mathrm{H}$ & 4.63 & 5.46 & 4.80 \\
$\mathrm{~N}$ & 1.47 & 0.19 & 1.21 \\
$\mathrm{~S}$ & 1.54 & 0.01 & 1.23 \\
$\mathrm{O}$ & 6.43 & 39.55 & 13.05 \\
Ash & 12.19 & 0.42 & 9.84 \\
Moisture & 4.23 & 9.52 & 5.29 \\
Total & 100.00 & 100.00 & 100.00 \\
\hline
\end{tabular}

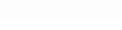

\section{Co-firing of Coal and Biomass}

- Operating conditions

- based on the provided operating condition with $3.33 \%$

furnace exit $\mathrm{O}_{2}$ concentration (20\% Saudust-80\% PrattSeam-

$3.33 \%$ FEO-75.7\% OFA.x/s)

\begin{tabular}{lcc} 
Primary air flow rate [SCFM] & 133.0 & 125.2 \\
Secondary air flow rate [SCFM] & 474.7 & 447.0 \\
Tertiary air flow rate [SCFM] & $\mathbf{1 0 8 . 0}$ & 101.7 \\
& & \\
Firing Rate [MMBTU/HR] & 3.65 & \\
Primary air temperature [DEGF] & 150.1 & \\
Secondary air temperature [DEGF] & 600.1 & \\
Pulverized coal feed rate to furnace [LB/HR] & 317.2 & \\
Furnace Exit Oxygen, wet [\%] & 3.33 & \\
Stoichiometric Ratio & 1.2 & \\
\hline
\end{tabular}

*Air fow mates were adjusted luased on 3.33\% /untuace exit oxygen. Acoondingly, overal/ stovichometric natio anas calculated as 1.2 . 


\section{Gas Temperature}
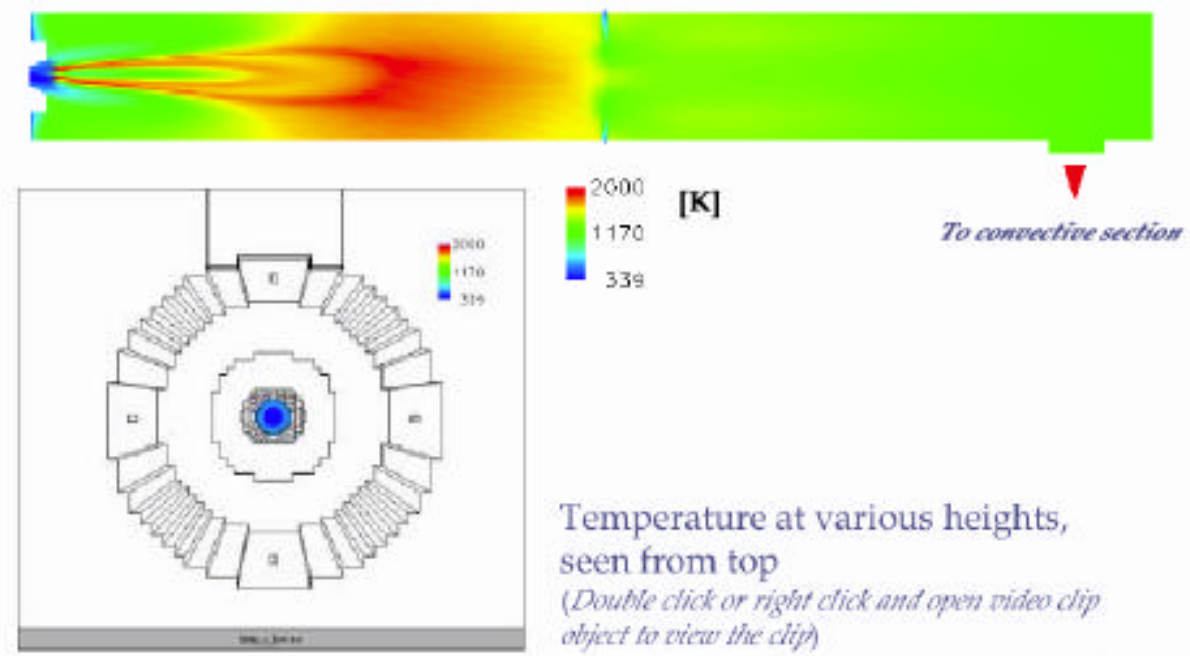

Temperature at various heights, seen from top

(Double click or righ click and open wideo dip) object fo wiew the clip)

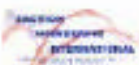

\section{Comparison : Gas Temperature}

$100 \%$ Pratt seam coal

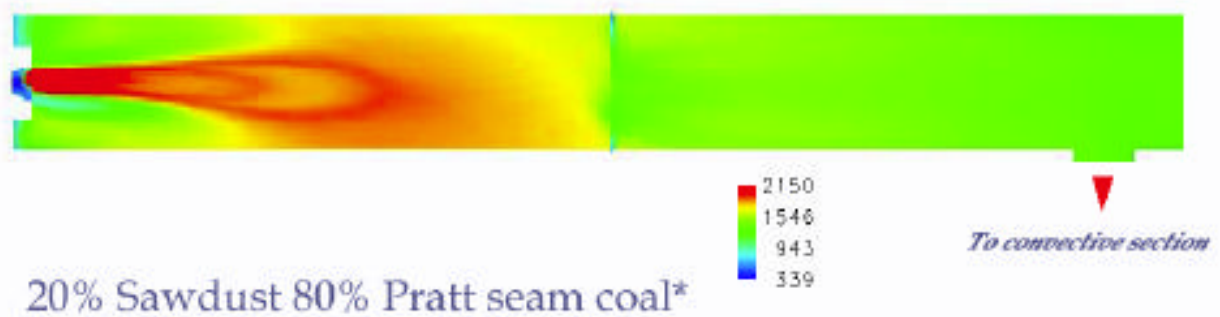

$20 \%$ Sawdust $80 \%$ Pratt seam coal

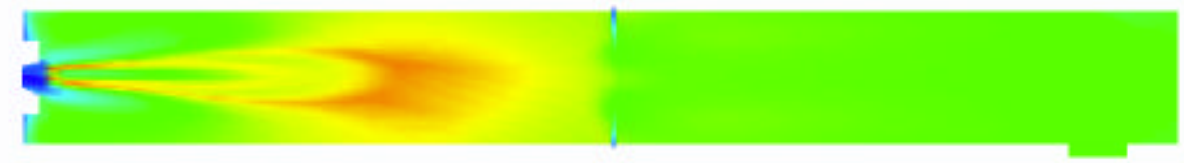

* Note that operating condition is different from $100 \%$ coal case. 


\section{Stoichiometric Ratio}

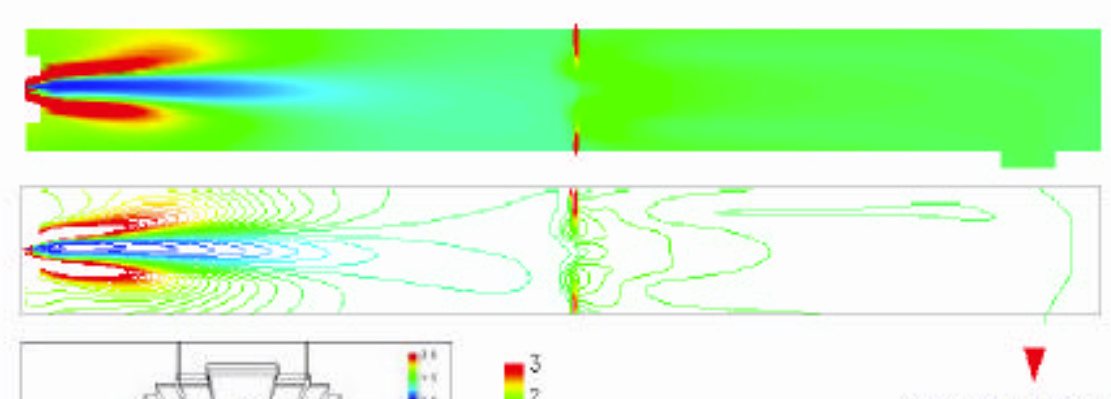

To compectrioe section

Stoichiometric ratio at various heights

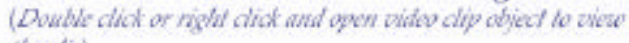
the dipt)

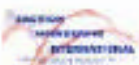

\section{Furnace Section 5 \& 7}

\section{Section 5}

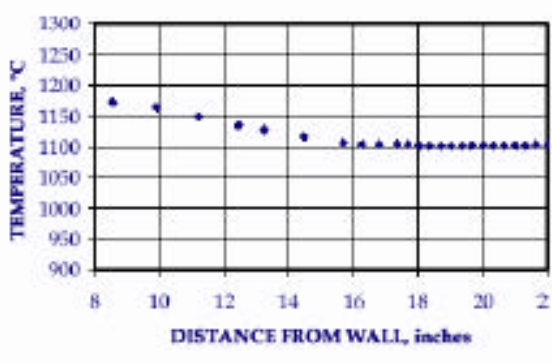

Section 7

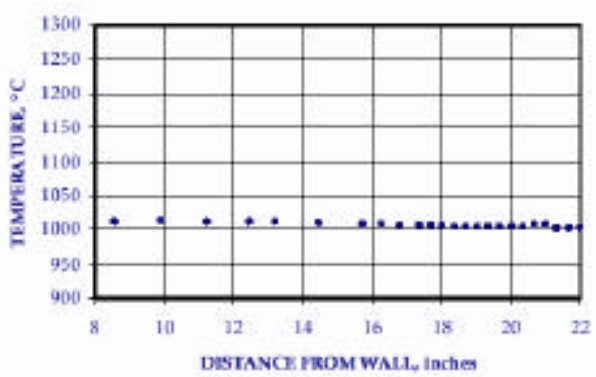




\section{APPENDIX C}

Presentation made at NETL Biomass Cofiring Project Review Meeting, 6/21/01

C-1

C-1 


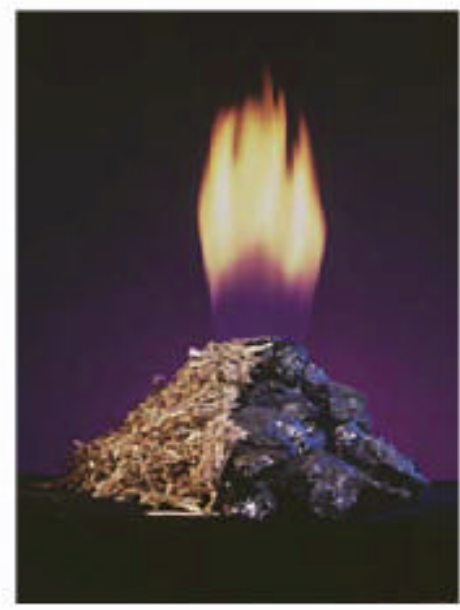

\section{Development of a Validated Model for Use in Minimizing $\mathrm{NO}_{\mathbf{x}}$ Emissions and Maximizing Carbon Utilization When Cofiring Biomass with Coal}

\section{Project Team}

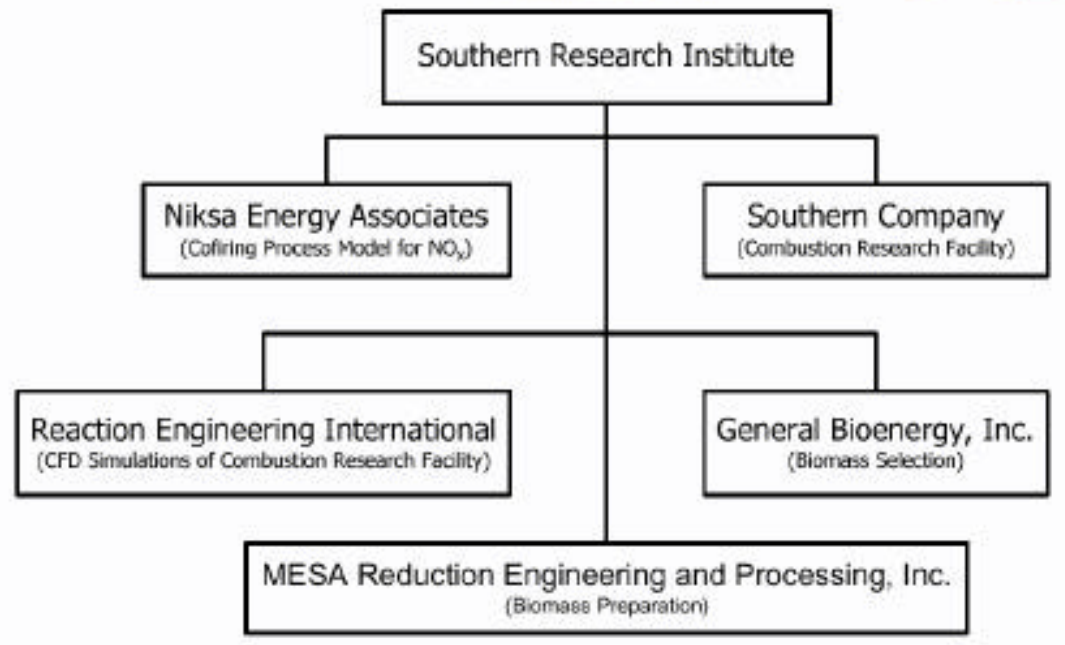




\section{Specific Program Objectives}

* Develop a consistent, extensive biomass cofiring database

- relationships between NOx and biomass cofiring parameters

- effects on flame stability, carbon burnout, slagging and fouling, and particulate and gaseous emissions

* Develop and validate a biomass cofiring model

- forecast NOx and LOI for given fuel combination with specified cofiring configuration

- optimize cofiring configuration to minimize NOx and unburned carbon for specified fuels

\section{Project Flow Chart}

CFD Model of Combustor

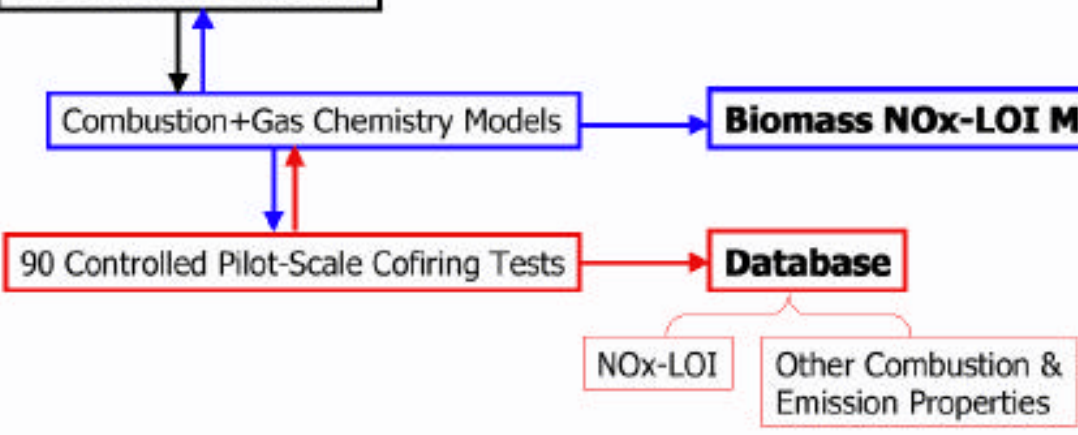




\section{Overall Project Timeline}

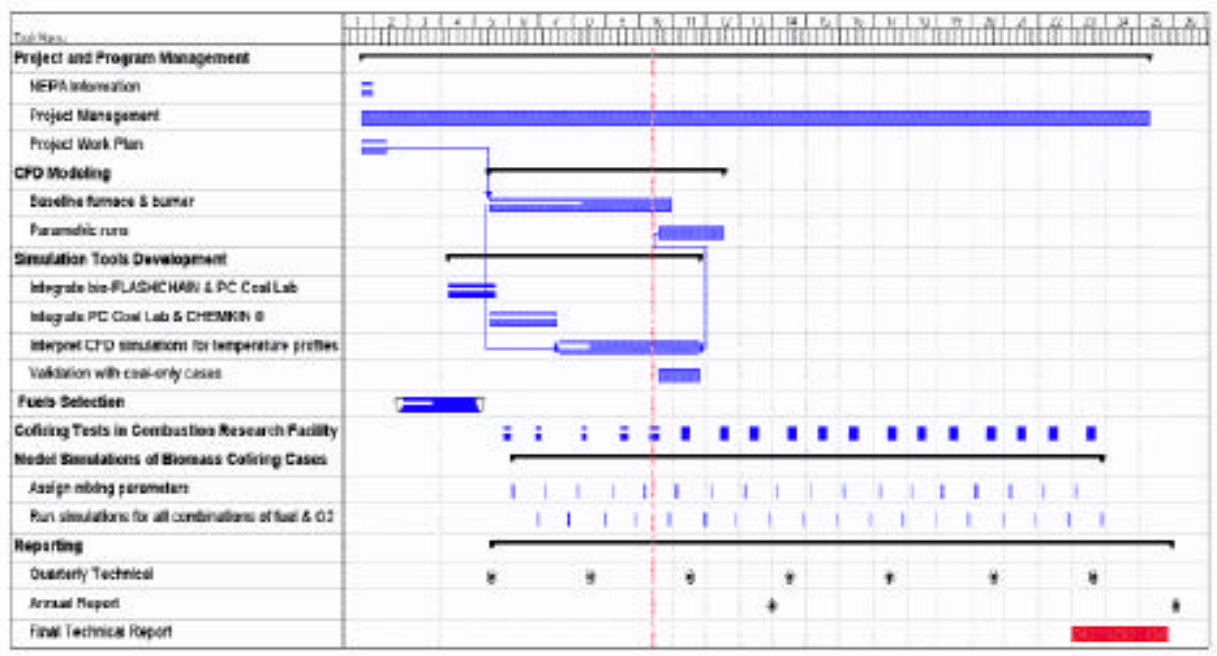

\section{Recent Project Timeline}

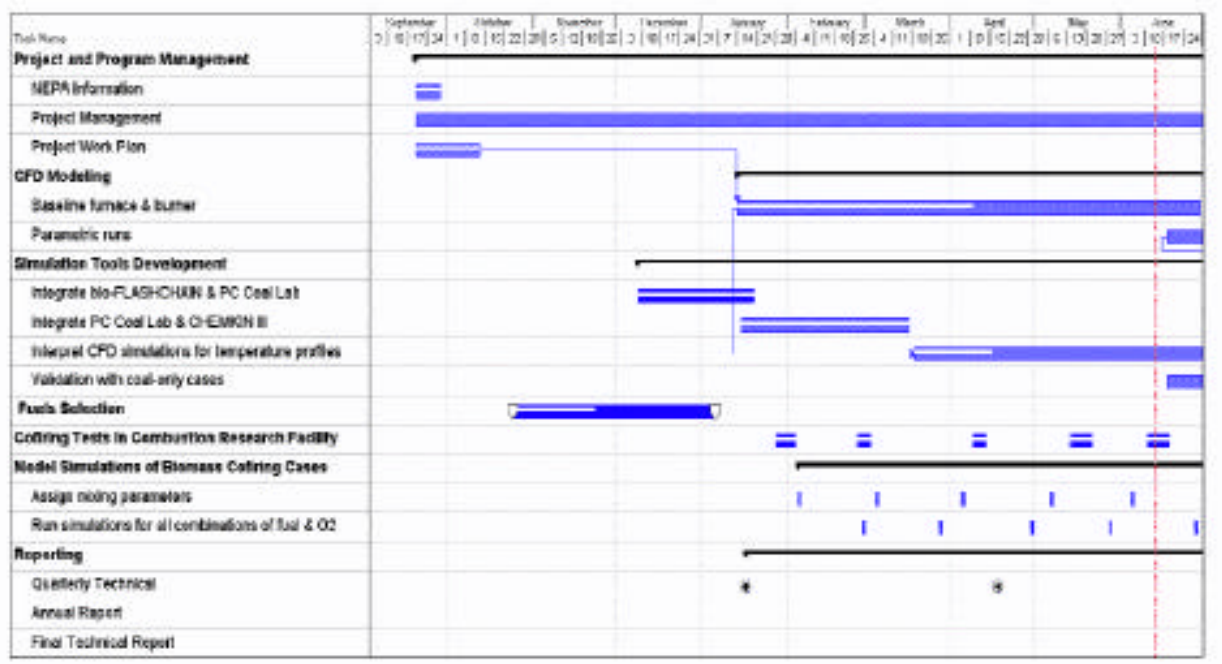




\section{REI - CFD Modeling of Combustor}

* Completed simulation of furnace firing Pratt Seam Coal with single register burner (April)

- GLACIER simulation of single register burner

- Furnace/convective section simulated

- Good agreement with measured furnace temperatures

* Ready to simulate furnace when cofiring biomass with coal (June)

- Sawdust and Switchgrass comilled with Pratt Seam coal

- Compare with parametric test results

\section{CFD Modeling of Combustor-To Do}

* Complete simulation of furnace firing Pratt Seam Coal with dual register burner

* Simulate furnace with other biomass injection schemes:

- Center of burner

- Near quarl (intersecting flame and and parallel to flame)

- Above quarl, into flame

* Compare with parametric Test Results 


\section{REI Results from CFD Modeling - 1}

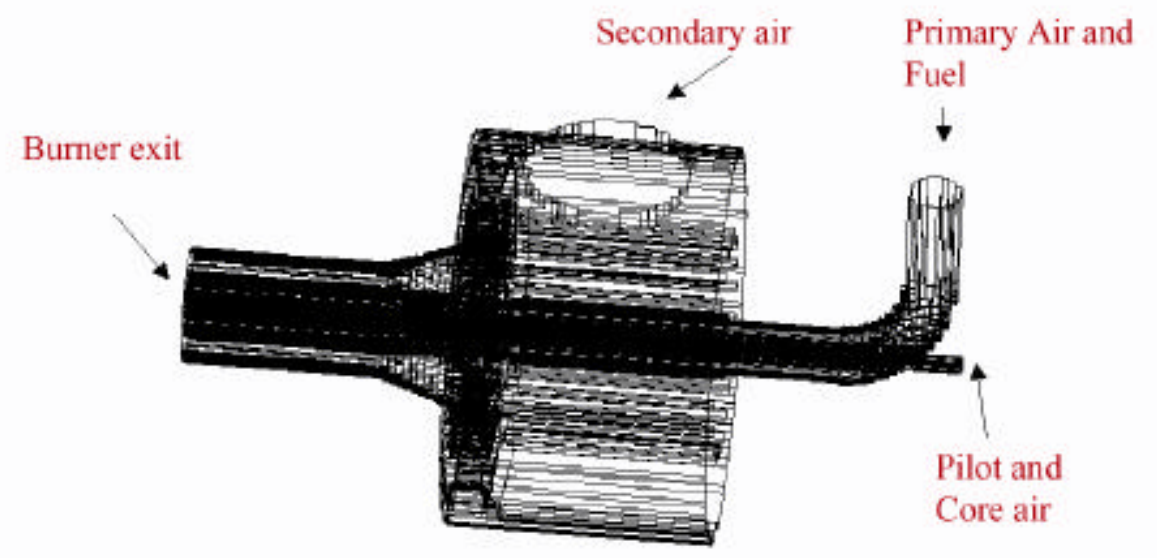

Schematic of Single Register Burner

\section{REI Results from CFD Modeling - 2}

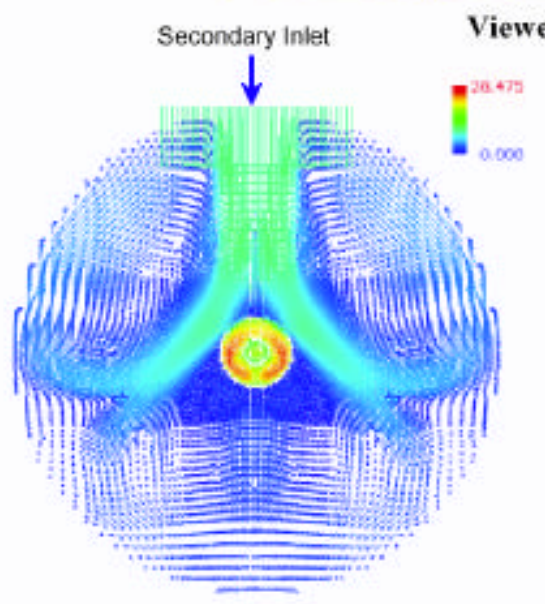

18. $8^{-}$from the bottom of the primary inlet

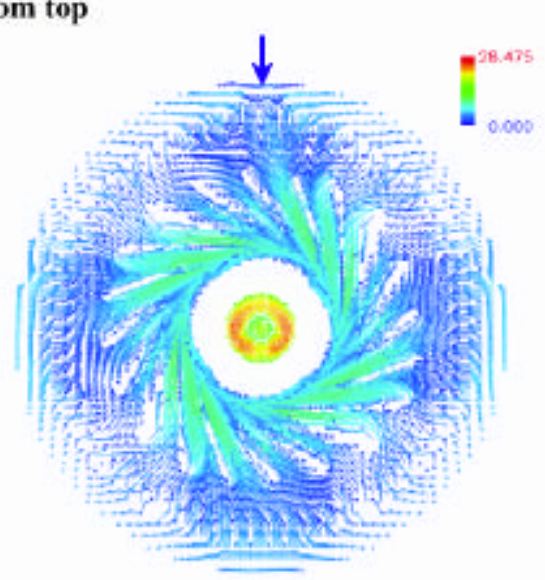

$27.3^{*}$ from the bottom of the primary inlet 


\section{REI Results from CFD Modeling - 3}

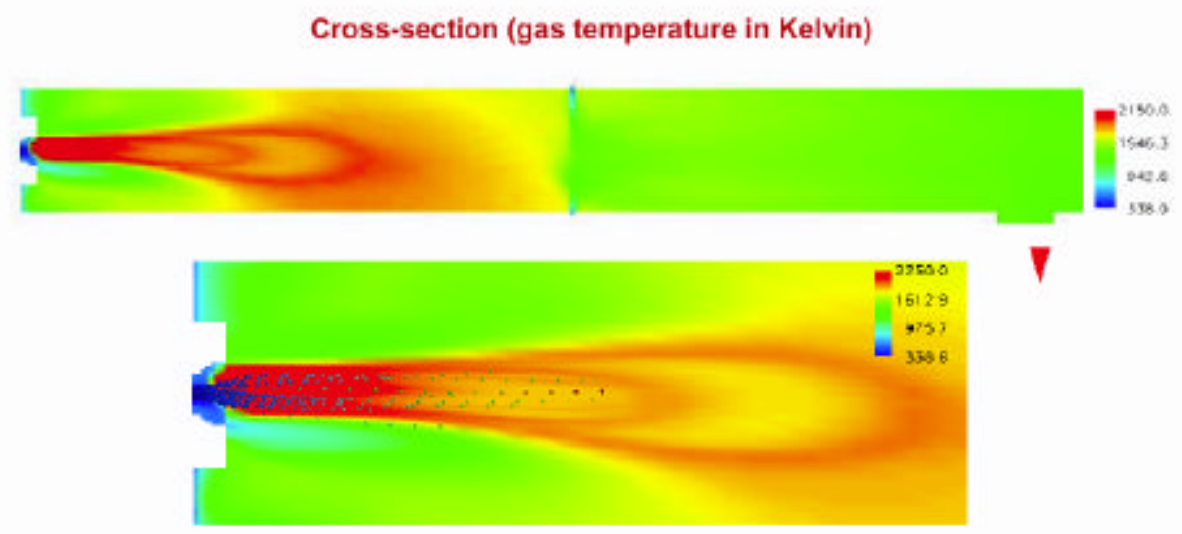

\section{REI Results from CFD Modeling - 4}

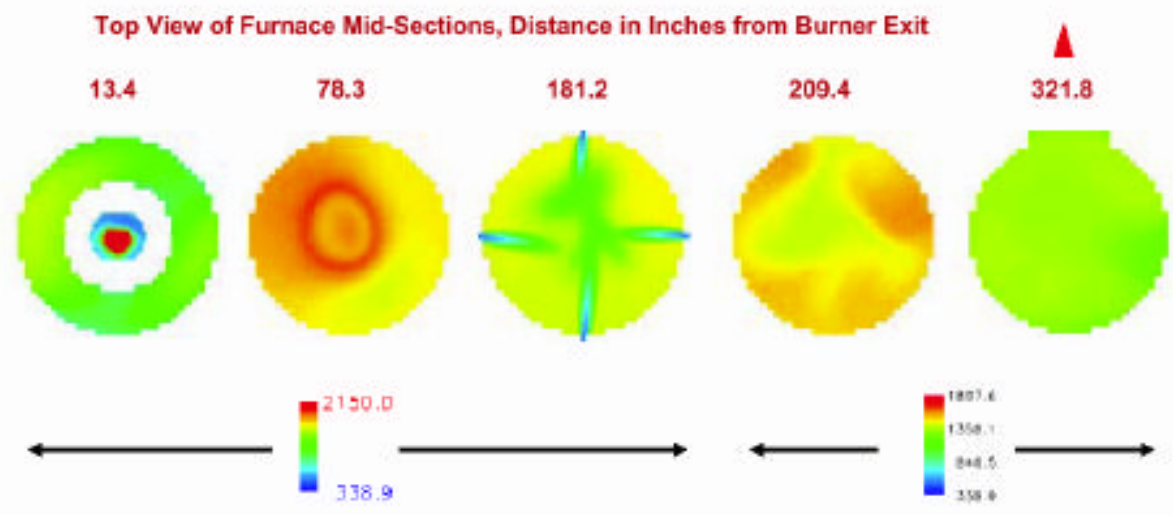




\section{$\mathrm{NEA}-\mathrm{NO}_{x} /$ LOI Model}

* Simulate detailed chemistry of biomass cofiring over an equivalent network of idealized reactors

- Provide advanced submodels for coal/biomass devolatilization and burnout

- Work with REI to specify the network of equivalent reactors from the CFD simulations

- Develop a computer program that incorporates detailed chemical reaction mechanisms into the equivalent network

* Validate the simulations for every test case in the SoRI/SCS furnace

- First, validate for coal-only baseline cases

- Compare with parametric test results

\section{$\mathrm{NEA}-\mathrm{NO}_{\mathrm{x}} /$ LOI Model Needs}

* Detailed Chemical Mechanisms and Turbulent Mixing Submodels are Needed for This Application

- Use CFD simulations to characterize the temperature fields and mixing intensities in the SRI test facility

- Develop an equivalent network of idealized reactor elements for each cofiring configuration

- Apply detailed chemical submodels to describe fuel-N conversion and burnout throughout the reactor network 


\section{NEA - $\mathrm{NO}_{x} /$ LOI Model Components}

* Independent Components of the Model Development:

- Incorporate fuel decomposition submodels, including NEA's bioFLASHCHAIN for biomass \& coal devolatilization and Prof. R. H. Hurt's CBK model for char burnout

- Simulate combustion and fuel- $\mathrm{N}$ conversion in the gas phase, based on Prof. Glarborg's reburning mechanism

- Identify an equivalent network of Continuously Stirred Tank Reactors (CSTR) and Pulse Flow Reactors (PFR) from the CFD simulations

\section{NEA - Progress to Date}

* Submodels for biomass devolatilization and combustion have been successfully incorporated into a comprehensive fuel decomposition submodel (PC Coal Lab ${ }^{\circledR}$ )

* NEA specified rate constants for biomass/coal devolatilization and combustion for REl's CFD simulations

* A computer program has been developed to simulate the chemistry of fuel decomposition and $\mathrm{N}$-conversion in the near-burner region of a single-burner flame 


\section{NEA - Incorporating Commercial Software}

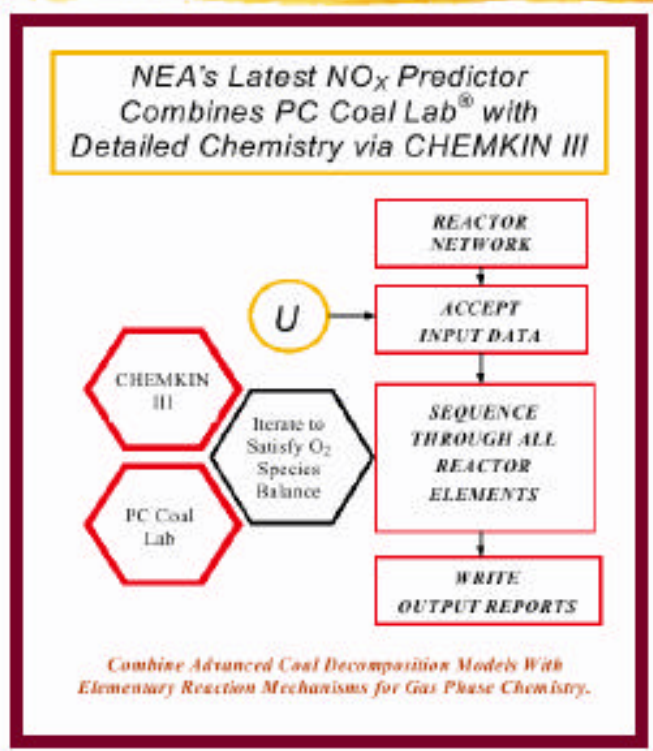

\section{NEA - Short-Term Objectives}

* Specify the equivalent reactor network for the SoRI/SCS furnace flame from REI CFD simulations

* Calibrate/validate chemistry simulations with coal-only baseline cases

* Begin simulations for the available co-firing test cases 


\section{SoRI/SCS - Combustion Research Facility}

- All testing conducted at the SoRI/SCS $6 \mathrm{MBtu} / \mathrm{hr}$ Combustion Research Facility (at 3.6 MBtu/hr)

- Continuous measurement and logging of over 180 pertinent process parameters (Yokogawa CS-1000 DCS)

- In-situ testing for mass emissions, particle size, furnace temperature, ash resistivity, gases $\left(\mathrm{O}_{2}\right.$ at furnace exit and at CEM location, $\mathrm{CO}, \mathrm{CO}_{2}, \mathrm{SO}_{2}, \mathrm{NO}_{\mathrm{x}}$ - Adding $\mathrm{H}_{2} \mathrm{O}, \mathrm{HCl}$ ).

- On-site wet chemical flue gas and ash analyses, CHN (for LOI), fuel heat value measurement

- Instrumented CE-Raymond Model 352 Deep Bowl mill

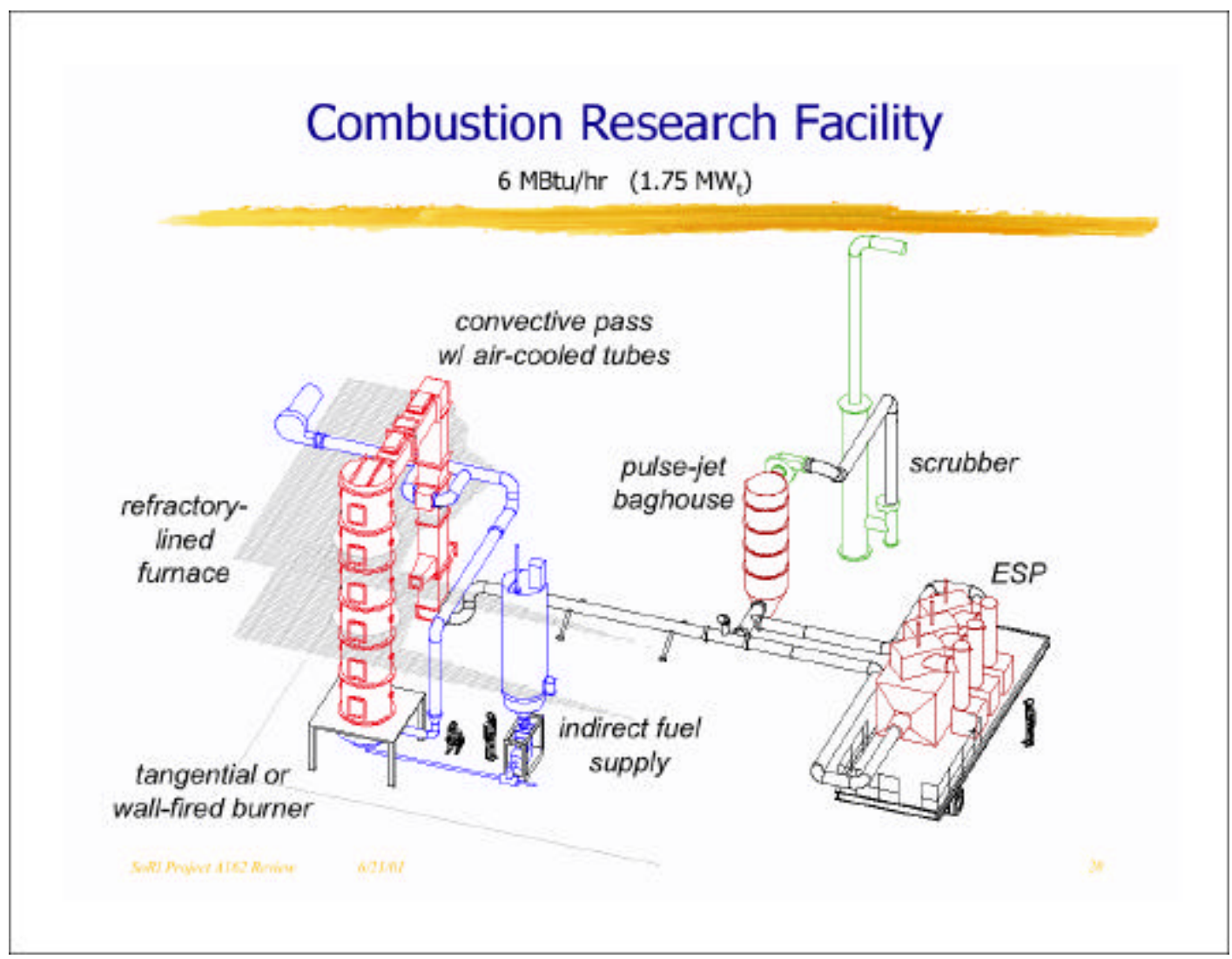




\section{Combustion Research Facility}
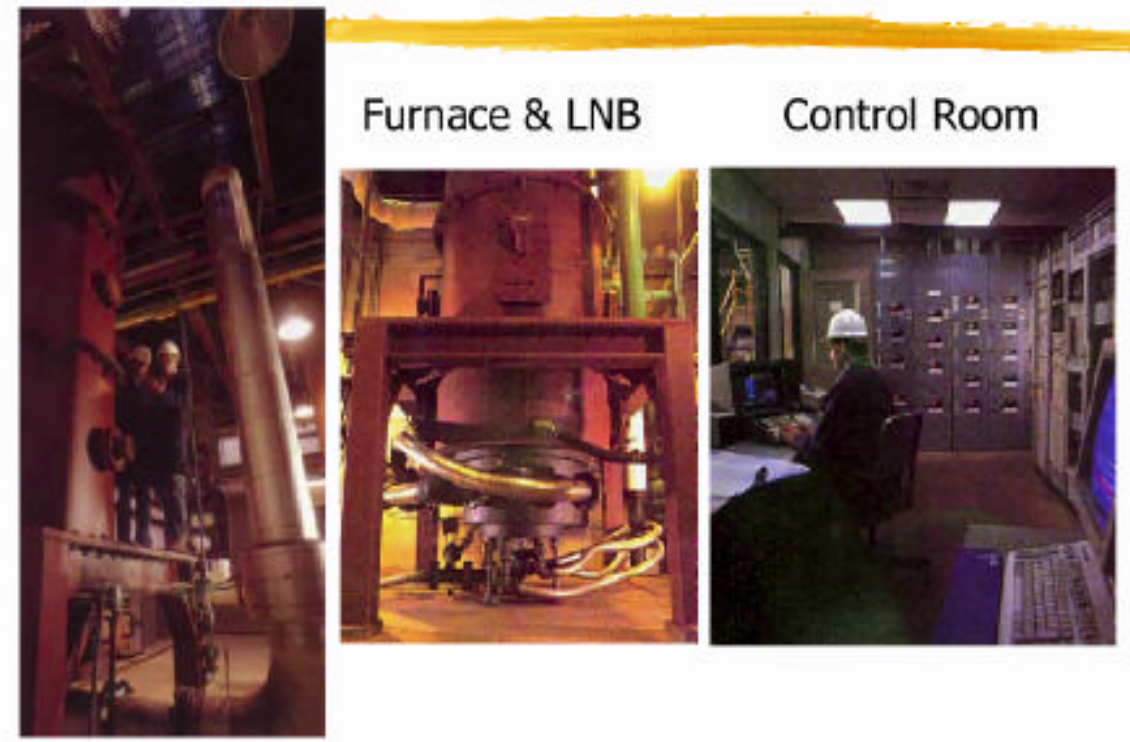

\section{Combustion Research Facility}

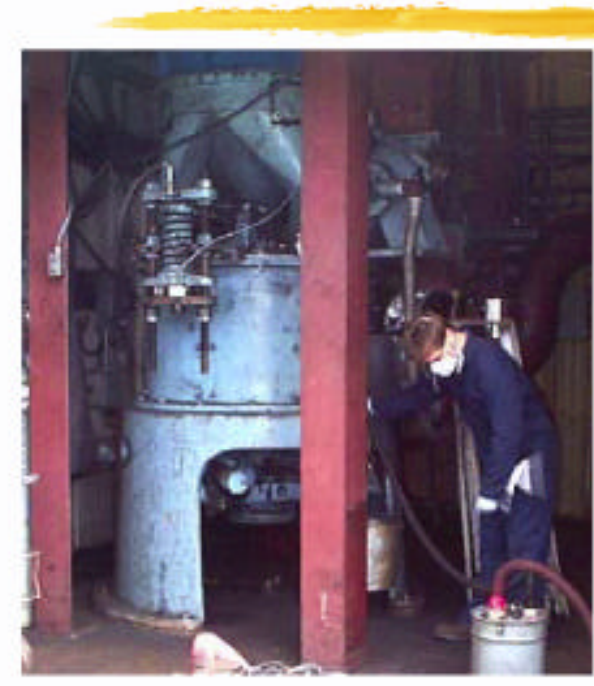

CE-Raymond Bowl Mill

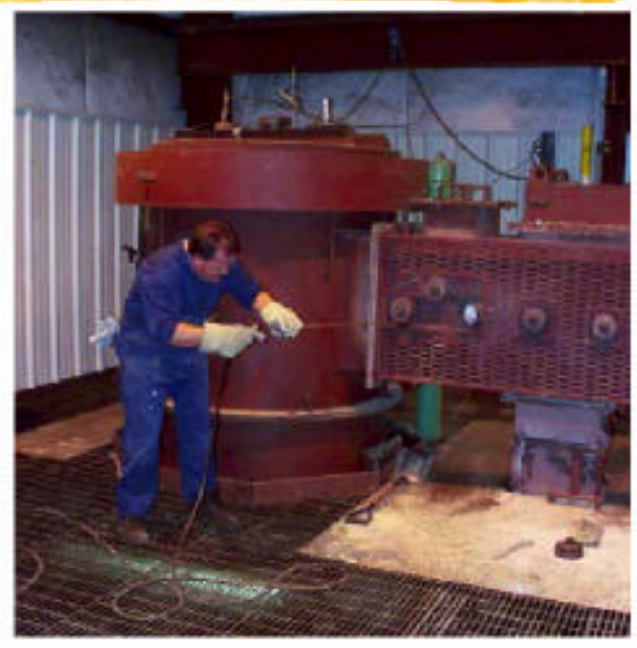

Furnace Convective Section 


\section{Controlled Variables in Cofiring Tests}

- Biomass types (spanning the range of fuel nitrogen and volatile/fixed carbon ratios that may be encountered)

- Biomass particle size

- Coal types (representing the most widely used coals in the utility market)

- Fuel mixing conditions

- Burner configurations

- Time-temperature profile and fuel-air mixing conditions in the combustion region have to match full-scale boilers

\section{Major Variables within the Test Matrix}

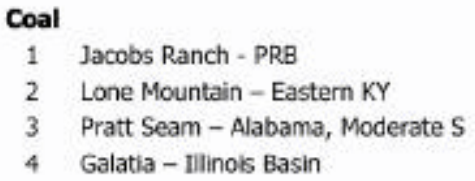

1 Jacobs Ranch - PRB

2 Lone Mountain - Eastern KY

3 Pratt Seam - Alabama, Moderate S

4 Galatia - Illinols Basin

Biomass

1 Switchgrass

\section{Poultry Litter}

Coastal Bermuda Grass

Green Hardwood Sawdust (Wet)

Green Hardwood Sawdust (Dry)

Willow

Hybrid Poplar

Rice Straw
Burner Configuration

A Tangential Burner

B Generic, Low NO, Dual Register Burner

Biomass Injection Scheme (Either Burner)

0 Burner alone, no Biomass

1 Co-milled, Injected with Coal

2 Through Center of Burner

3 Off-Axis, Direct Injection into flame

4 Off-Axis, Direct Injection parallel to flame

\section{Biomass Quantity}

$0 \%-100 \%$ Coal

$10 \%-90 \%$ Coal

$20 \%-80 \%$ Coal 


\section{Biomass Selected for Pilot-Scale Tests}

Switchgrass: preferred herbaceous crop, $1.5 \%$ fuel N

Dry sawdust: abundant forest products waste, $0.15 \%$ fuel $\mathrm{N}$

Wet sawdust: evaluate combustion thermal effects

Coastal Bermuda: grass with relatively high fuel $\mathrm{N}$

Poplar \& willow: preferred woody crops, low fuel N

Poultry litter: available farm waste, $5 \%$ fuel $\mathrm{N}$

Rice straw: regional agricultural residue

\section{Biomass Injection Cases}

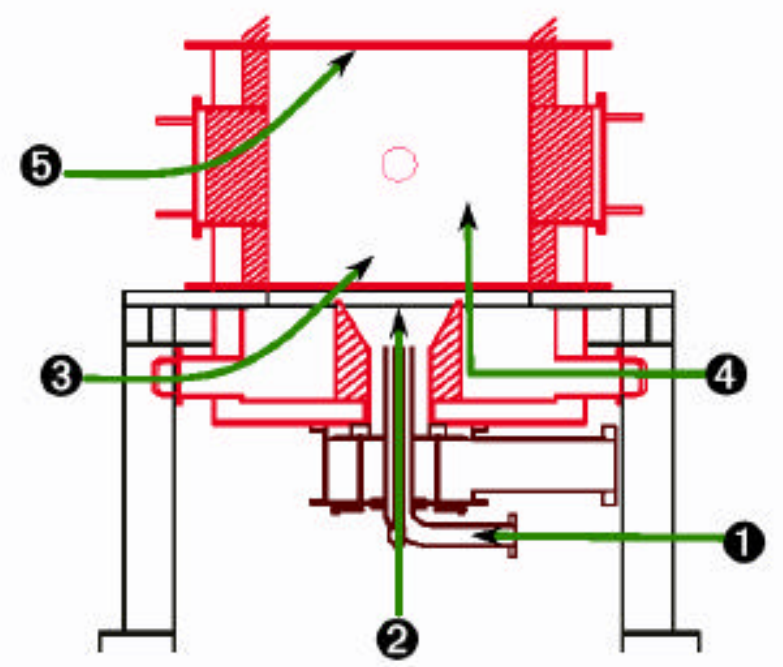




\section{Matrix of Proposed Tests}

\begin{tabular}{|c|c|c|c|c|c|c|c|c|c|}
\hline \multirow{2}{*}{$\begin{array}{c}\text { Test } \\
\text { Number }\end{array}$} & \multicolumn{2}{|c|}{ Coal Choice } & \multicolumn{2}{|c|}{ Burner-Injection Scheme } & \multicolumn{5}{|c|}{ Bomass Fuel - \% Biomass } \\
\hline & First & Second & First & Second & Day 1 & Day 2 & Day 3 & Day 4 & Day 5 \\
\hline 1 & 1 & & $A=0$ & $A-2$ & $1-0$ & $1 \cdot 10$ & 1.20 & $2-10$ & $2 \cdot 20$ \\
\hline 2 & 1 & & A. 2 & & $3-10$ & $4-10$ & $5-10$ & $5 \cdot 20$ & $6-10$ \\
\hline 3 & 1 & & A. 2 & A- 1 & $7 \cdot 10$ & $8 \cdot 10$ & $1-10$ & $2-10$ & $5-10$ \\
\hline 4 & 1 & & $A-1$ & & $3 \cdot 10$ & $4 \cdot 10$ & $6-10$ & $7 \cdot 10$ & $8 \cdot 10$ \\
\hline 5 & 1 & & $A \cdot 3$ & & 1.10 & $1 \cdot 20$ & $2-10$ & $2 \cdot 20$ & $5 \cdot 10$ \\
\hline 5 & 1 & & A. 4 & & $1 \cdot 10$ & $1-20$ & $2-10$ & $2-20$ & $5 \cdot 10$ \\
\hline 7 & 2 & & $A-0$ & $A-2$ & $1 \cdot 0$ & $1-10$ & $1-20$ & $2-10$ & 2.20 \\
\hline 8 & 2 & & $A-2$ & & $3-10$ & $4 \cdot 10$ & $5-10$ & $5 \cdot 20$ & $6 \cdot 10$ \\
\hline 9 & 2 & & A. 2 & A -1 & $7 \cdot 10$ & $8 \cdot 10$ & $1-10$ & $2-10$ & $5-10$ \\
\hline 10 & 2 & & $A-1$ & & $3 \cdot 10$ & $4 \cdot 10$ & $6-10$ & $7 \cdot 10$ & $8 \cdot 10$ \\
\hline 11 & 2 & & $A \cdot 3$ & & $1 \cdot 10$ & $1 \cdot 20$ & $2-10$ & $2-20$ & $5 \cdot 10$ \\
\hline 12 & 2 & & $A=4$ & & 1.10 & $1-20$ & $2-10$ & $2-20$ & $5 \cdot 10$ \\
\hline 13 & 3 & & B-O & $8-2$ & 1.0 & $1-10$ & 2.10 & $5-10$ & $8-10$ \\
\hline 14 & 4 & & B. 0 & 8.2 & 1.0 & $1 \cdot 10$ & $2 \cdot 10$ & $5-10$ & $8-10$ \\
\hline 15 & 3 & 4 & $B-1$ & & $1 \cdot 10$ & $2 \cdot 10$ & $5-10$ & $1-10$ & $2-10$ \\
\hline 16 & 3 & 4 & B. 3 & & $1-10$ & $2 \cdot 10$ & $5-10$ & $1-10$ & $2-10$ \\
\hline 17 & 3 & 4 & B -4 & & $1-10$ & $2-10$ & $5-10$ & $1-10$ & $2 \cdot 10$ \\
\hline 18 & 1 & 2 & B- 2 & & $1-10$ & $2 \cdot 10$ & $5-10$ & $1-10$ & $2-10$ \\
\hline
\end{tabular}

Grayed areas are used to delineate the second of two canditions within a week of testing.

\section{Modified Test Matrix}

* Construction at the Combustion Research Facility has temporarily reduced our capacity for fuel storage.

* Because of reduced storage, testing started with coal and stable biomasses that could be obtained on short notice.

* Construction should be finished in August, at which time sufficient quantities of other coals and biomasses will be stockpiled for subsequent use. 


\section{Coal Selected for Pilot-Scale Tests}

\begin{tabular}{|r|r|r|r|r|}
\hline & & \multicolumn{3}{|c|}{ Coal Source } \\
Analysis & Jacobs Ranch & Lone Mountain & Pratt Seam & Galatia \\
\hline Proximate (As Received) & & & & \\
\hline Moisture, \% & 10.19 & 1.89 & 2.25 & 5.50 \\
Ash, \% & 6.49 & 6.50 & 12.84 & 6.74 \\
Volatile, \% & 39.73 & 34.15 & 29.02 & 34.00 \\
Fived Carbon, \% & 43.59 & 57.45 & 55.89 & 53.76 \\
Sulfur, \% & 0.51 & 0.87 & 1.49 & 1.34 \\
Heating Value, \% & 10356 & 13958 & 12919 & 12876 \\
& & & & \\
ultimate Analysis (Dry) & & & & \\
\hline Carton, \% & 68.97 & 79.68 & 74.53 & 76.60 \\
Hydrogen, \% & 4.25 & 4.94 & 4.33 & 5.13 \\
Nitrogen, \% & 0.99 & 1.55 & 1.45 & 1.68 \\
Sulfur, \% & 0.57 & 0.89 & 1.52 & 1.42 \\
Ash, \% & 7.23 & 6.63 & 13.14 & 7.13 \\
Toxygl, \% & 100.00 & 100.00 & 100.00 & 100.00 \\
Chiorine, \% & 0.04 & 0.03 & 0.01 & 0.31 \\
\hline
\end{tabular}

\section{Biomass Fired in Pilot-Scale Tests}

\begin{tabular}{|c|c|c|c|}
\hline Analysis & $\begin{array}{c}\text { Sewdust } \\
\text { (Red Oak) }\end{array}$ & $\begin{array}{c}\text { Biomass } \\
\text { Switchgrass } \\
\text { (Field Chopped) }\end{array}$ & $\begin{array}{c}\text { Switchgrass } \\
\text { (Baled) }\end{array}$ \\
\hline \multicolumn{4}{|l|}{ Proximate (As Received) } \\
\hline Moisture, \% & 3.11 & 15.18 & 9.53 \\
\hline Ash, \%6 & 0.52 & 29.53 & 5.95 \\
\hline Volatile, \% & 82.45 & 47,69 & 69.03 \\
\hline Fixed Carbon, \% & 13.92 & 7.60 & 15.49 \\
\hline Sulfur, \% & 0.01 & 0.21 & 0.20 \\
\hline Heating Value, \% & 8017 & 5891 & 7333 \\
\hline \multicolumn{4}{|l|}{ Ultimate Analysis (Dry) } \\
\hline Carbon, \% & 48.97 & 36.59 & 44.81 \\
\hline Hydrogen, \% & 6.09 & 3.50 & 5.84 \\
\hline Nitrogen, \% & 0.15 & 1.59 & 1.02 \\
\hline Sufur, \% & 0.01 & 0.25 & 0.22 \\
\hline Ash, \% & 0.54 & 34.82 & 6.58 \\
\hline Oxygen, $\%$ (Diff) & 44.24 & 23.25 & 41.53 \\
\hline Total, \% & 100.00 & 100.00 & 100.00 \\
\hline Chlorine, \% & 0.01 & 0.10 & NA \\
\hline
\end{tabular}




\section{Completed Tests - 1}

* Test 1: Pratt Seam Coal - Comilled Biomass, single register burner, 15\%, 20\% Switchgrass, 10\%, 20\% Sawdust. $0 \%, 15 \%, 30 \%$ overfire air. 1/28-2/3/01

* Test 2: Pratt Seam Coal-Biomass through center of burner (scheme 2), single register burner, $10 \%$ Sawdust. $0 \%, 15 \%$ overfire air. Problems with biomass injection scheme and flame stability. 2/25-3/2/01

* Test 3: Pratt Seam Coal-Biomass through center of burner (scheme 2), single register burner, 10\%, 20\% Switchgrass, $10 \%, 20 \%$ Sawdust. $0 \%, 15 \%$ overfire air. Continued problems with flame stability. 4/8-14/01

\section{Completed Tests - 2}

* Test 4: Pratt Seam Coal - no biomass, single register burner, extensive characterization of coal-only firing at $0 \%$ and $15 \%$ overfire air. Corrected flame stability problem. $5 / 14-17 / 01$

* Test 5: Pratt Seam Coal - Biomass injection toward quarl (scheme 3), single register burner, $10 \%, 20 \%$ Switchgrass, $10 \%, 20 \%$ Sawdust. $0 \%, 15 \%$ overfire air. $6 / 10-15 / 01$ 


\section{Upcoming Tests}

* To provide additional input for CFD and $\mathrm{NO}_{\mathrm{X}}$ modeling studies, Test 6 (July) will fire Galatia coal, comilled with switchgrass and sawdust.

* Tests 7 and 8 will fire Galatia coal with the same biomasses injected through the center of the burner (scheme 2) and toward the quarl (scheme 3).

\section{Typical Combustor Cofiring Test Data}

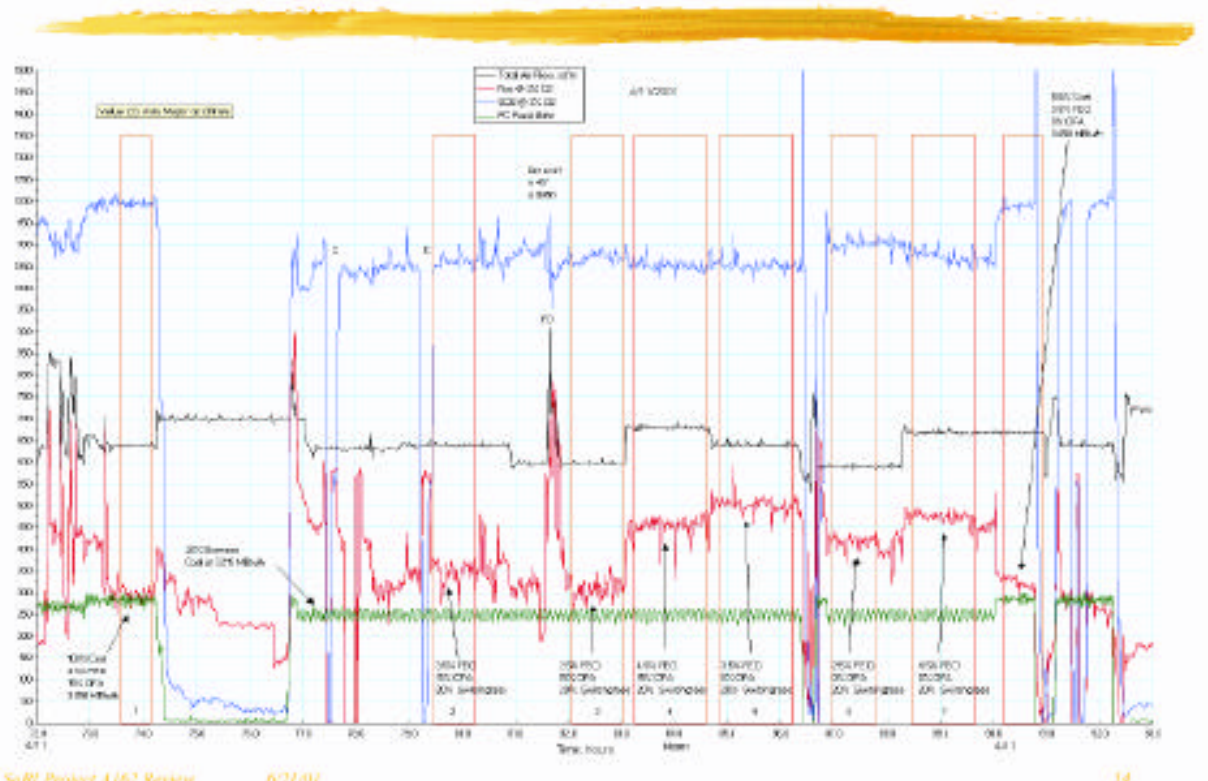




\section{Combustor Cofiring Test Data - Zoom In}

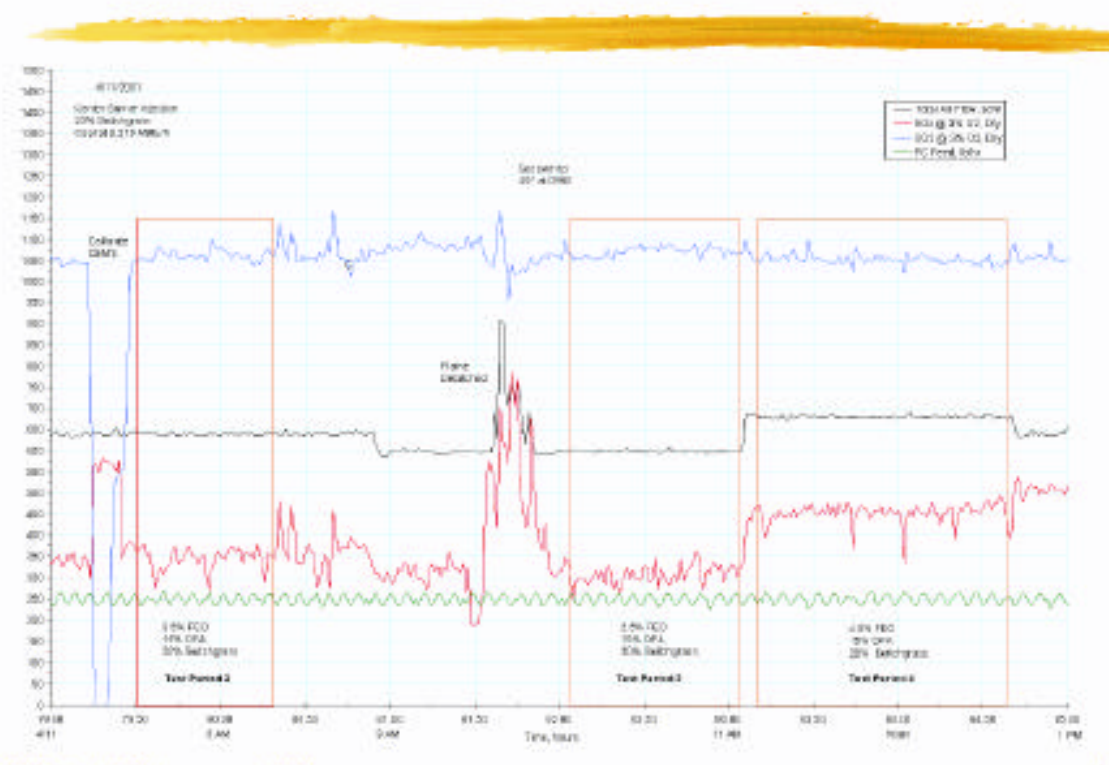

\section{Raw and Averaged Test Data}

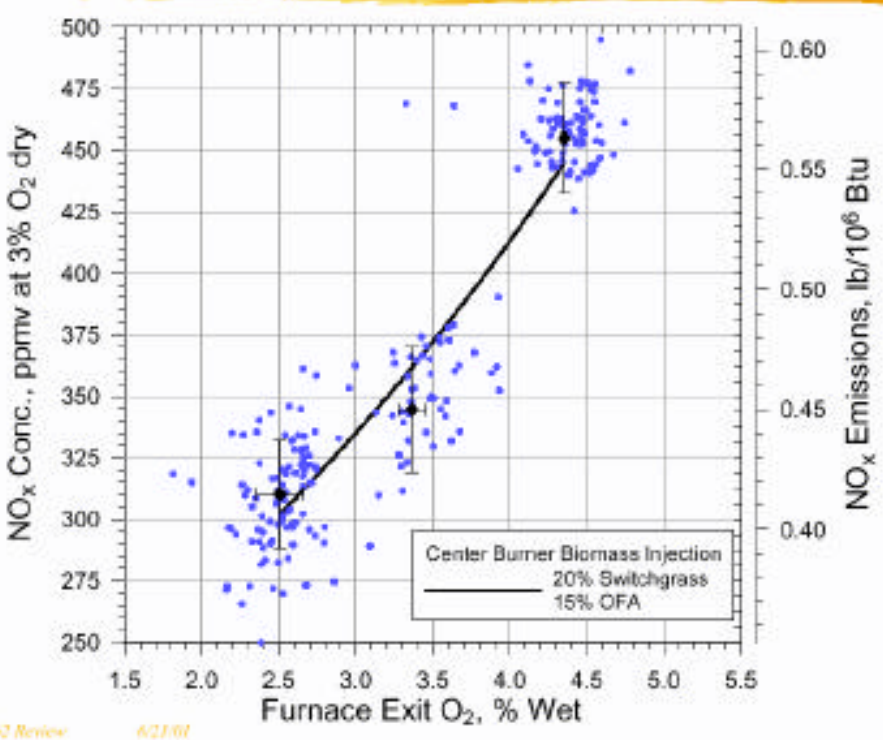




\section{Comilled versus Center Burner Injection}

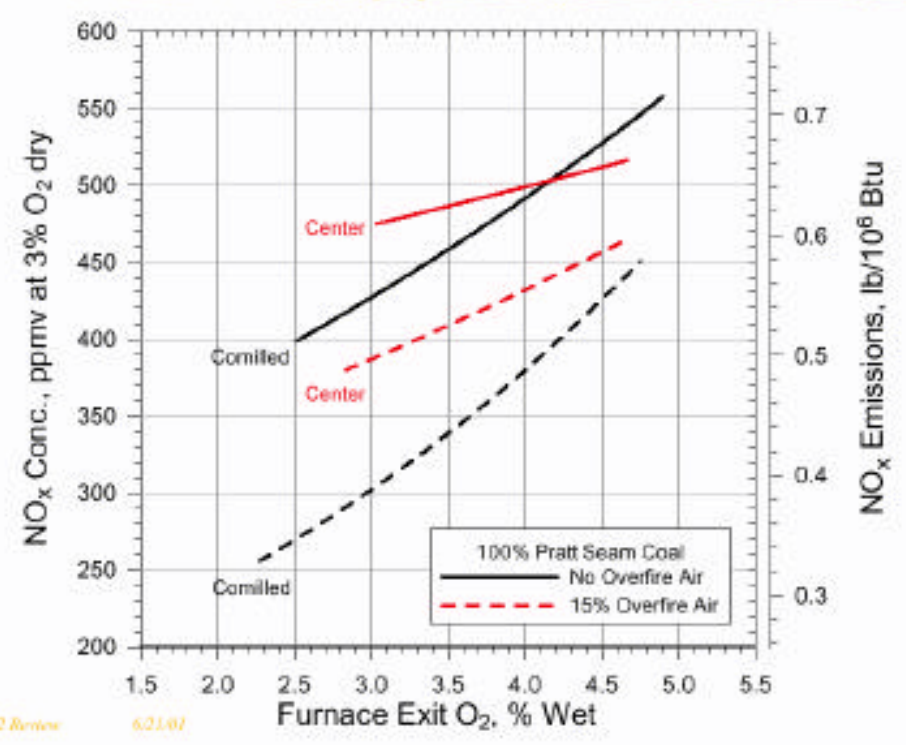

\section{Pratt Seam Coal Comilled with Biomass}

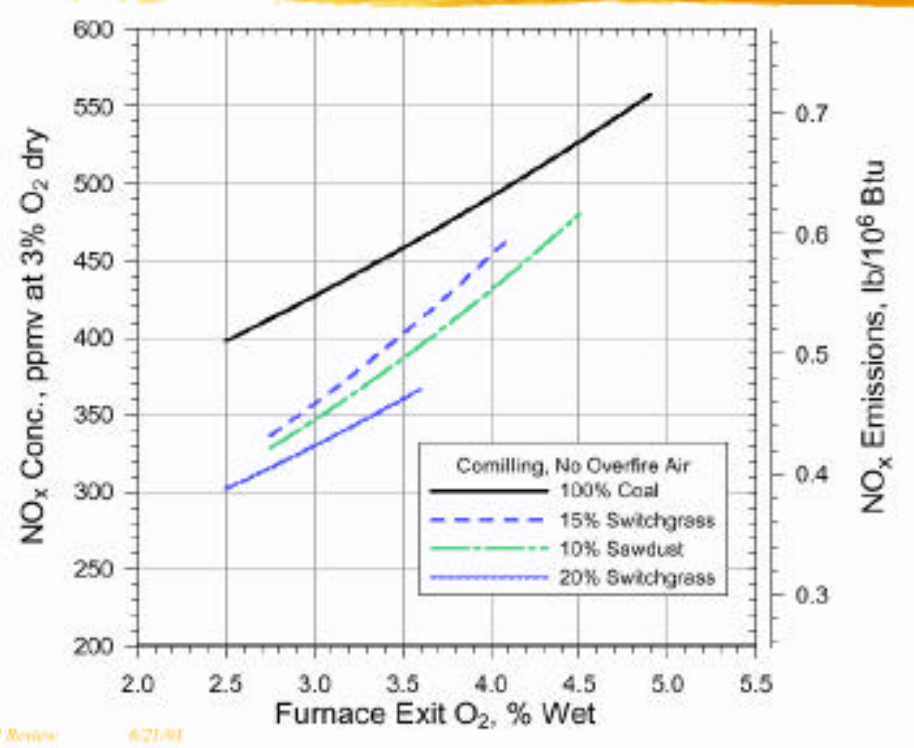




\section{Pratt Seam Coal Comilled with Biomass}

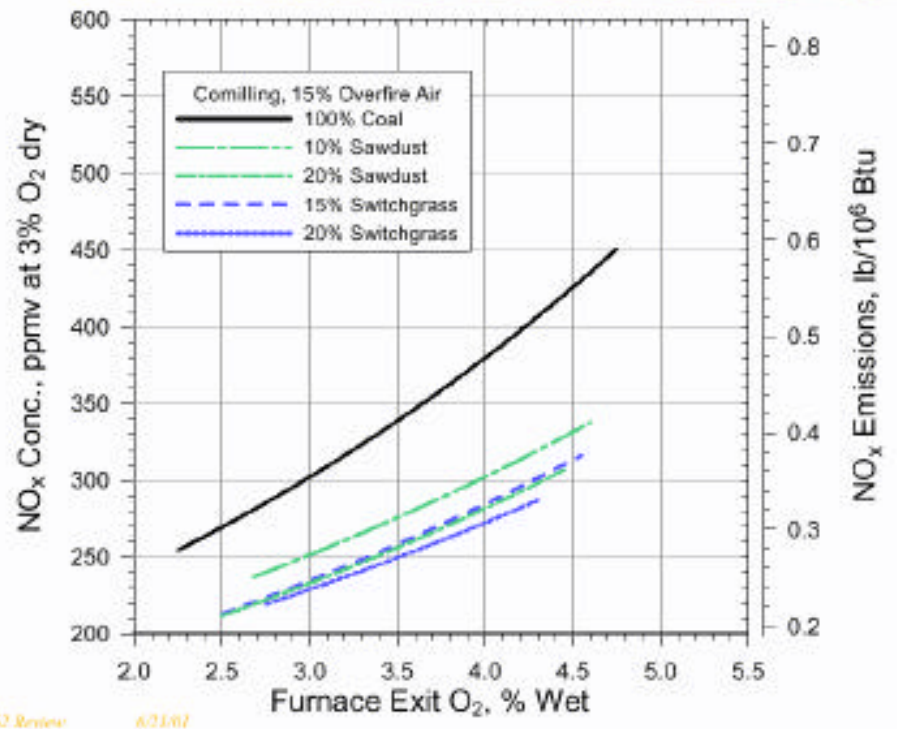

\section{Pratt Seam Coal - Center Biomass Inj.}

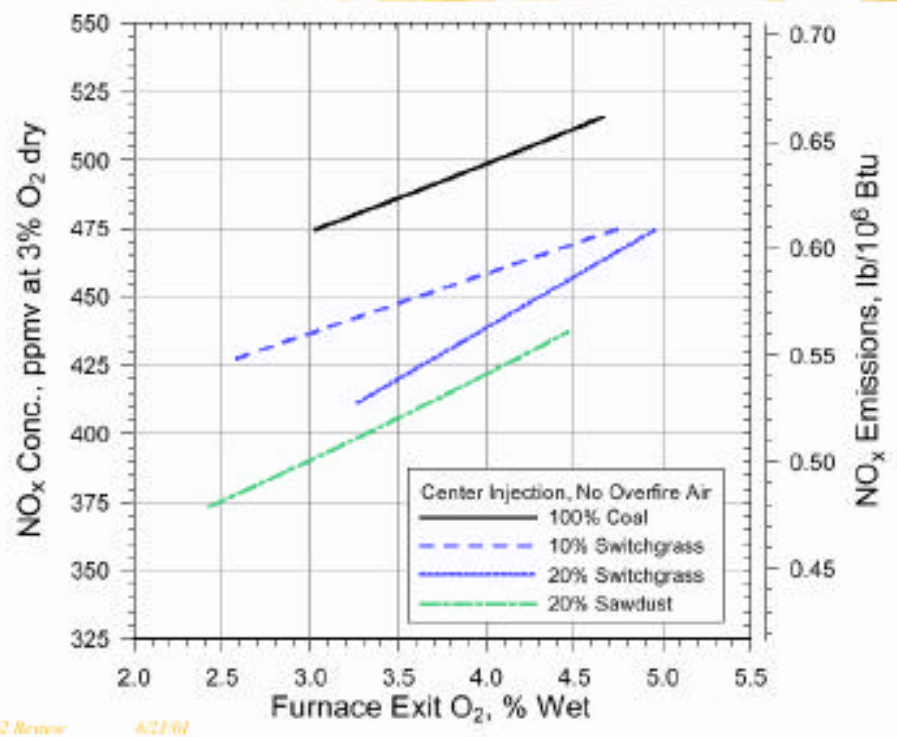




\section{Pratt Seam Coal - Center Biomass Inj.}

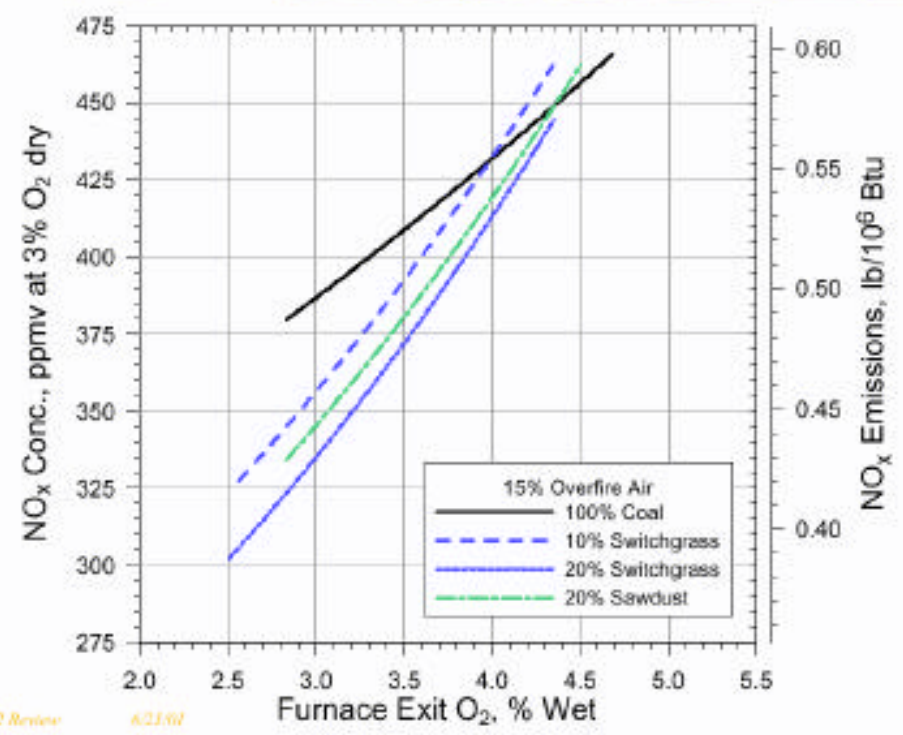

\section{Ongoing Analyses Not Shown}

* CHN analyses of EPA Method 17 (Mass Train) samples to measure unburned carbon as a function of furnace exit oxygen

* In situ mass concentrations (EPA Method 17), fly ash particle size distributions (cascade impactor), and ash resistivity

* Chemical analyses of coal, biomass, fly ash, furnace bottom, and furnace convective section ash

* Sieve analyses of pulverized coal, comilled coal and biomass, and milled biomass (from MESA Reductions)

* Furnace temperature distributions, pressures, and flows

* Gas analyses (other than $\mathrm{NO}_{X}$ ) from CEM system 